\title{
Petroleum: An Energy Profile, 1999
}

\author{
Energy Information Administration \\ Washington, DC 20585
}

DISTRIBUTION OF THIS DOCUREAT IS UMMPATED

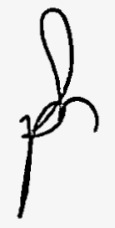

This report was prepared by the Energy Information Administration, the independent statistical and analytical agency within the U. S. Department of Energy. The information contained herein should not be construed as advocating or reflecting any policy position of the U.S. Department of Energy or of any other organization. 


\section{Contacts and Acknowledgments}

This report was prepared by the Energy Information Administration (EIA) under the direction of Dr. John Cook, Director, Petroleum Division, Office of Oil and Gas. The authors of this report are Dave Hinton, Nancy Masterson, Alice Lippert, and Robert King of the Office of Oil and Gas.

This report is an update of a previous EIA publication, Petroleum An Energy Profile, DOE/EIA-0545(91) (August 1, 1991).

Questions about this report can be directed to the National Energy Information Center, or at (202)586-8800. The EIA statistics provided in this report were the most current data available at time of publication. However, the user can update this report with the most current information by visiting our website at http://www.eia.doe.gov. See the end of each chapter for the names of specific publications that are pertinent to each chapter.

In addition to the many data publications cited in this report, EIA publishes many in-depth analyses of various aspects of the petroleum industry. For a current list of these reports, see our website mentioned above. Then select first "Petroleum" and then select "Analysis" or "Feature Articles."

The authors would like to acknowledge the contributions of Charles Riner, Carolyn Mack, Dave Morehouse, Stefanie Palumbo, Charles Shirkey, Mike Burdette, and Cynthia McLaughlin of the Office of Oil and Gas in preparing this report, and Ann Whitfield of the National Energy Information Center for the cover design. 


\section{DISCLAIMER}

This report was prepared as an account of work sponsored by an agency of the United States Government. Neither the United States Government nor any agency thereof, nor any of their employees, makes any warranty, express or implied, or assumes any legal liability or responsibility for the accuracy, completeness, or usefulness of any information, apparatus, product, or process disclosed, or represents that its use would not infringe privately owned rights. Reference herein to any specific commercial product, process, or service by trade name, trademark, manufacturer, or otherwise does not necessarily constitute or imply its endorsement, recommendation, or favoring by the United States Government or any agency thereof. The views and opinions of authors expressed herein do not necessarily state or reflect those of the United States Government or any agency thereof. 


\section{DISCLAIMER}

Portions of this document may be illegible in electronic image products. Images are produced from the best available original document. 


\section{Contents}

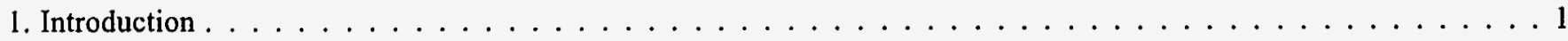

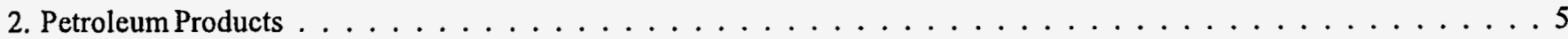

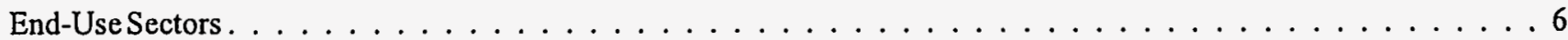

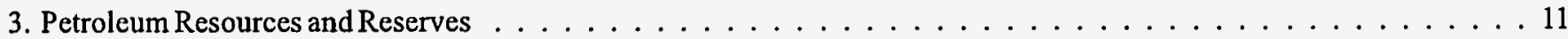

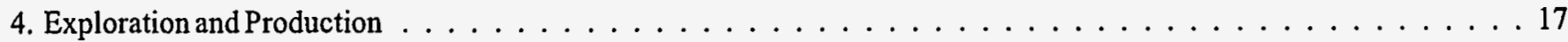

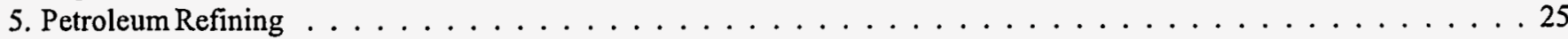

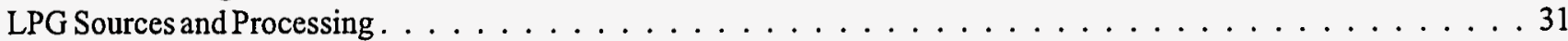

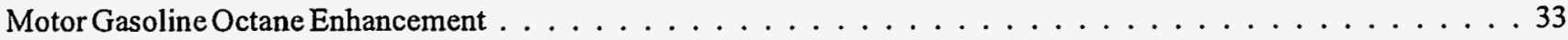

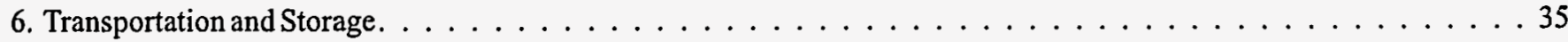

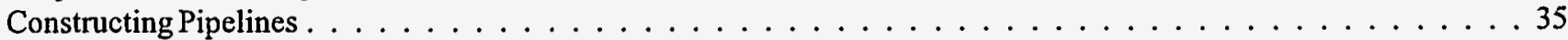

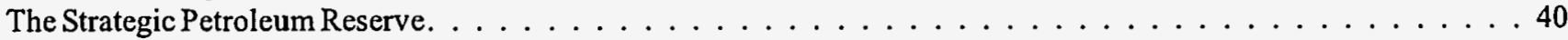

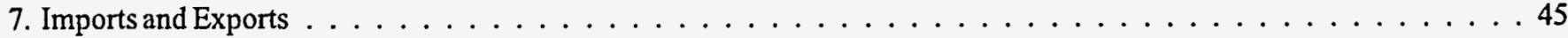

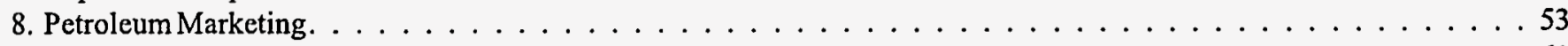

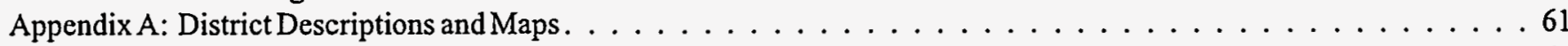

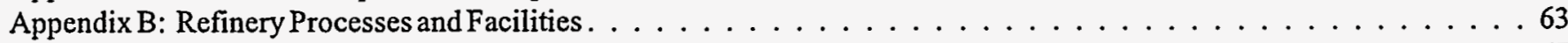

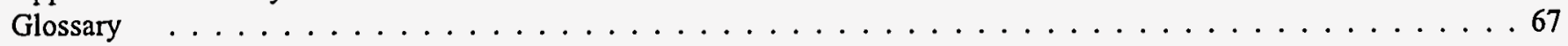

\section{Tables}

Table 3.1 Ten Largest Oil Fields in the United States as of January $1,1999 \ldots \ldots \ldots \ldots \ldots \ldots$

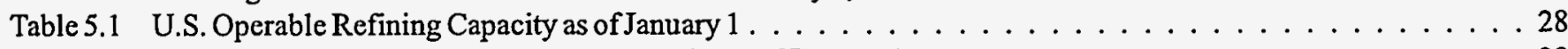

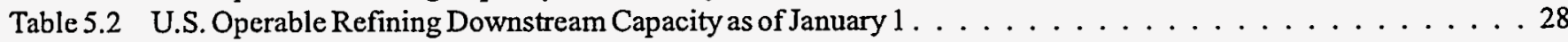

Table 5.3 U.S. Operable Production Capacity as of January $1 \ldots \ldots \ldots$. . . . . . . . . . . . . . . . . . . . . 29

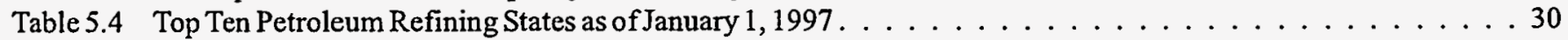

Table 6.1 U.S. Refinery Receipts of Crude Oil by Method of Transportation and Source, 1996 . . . . . . . . . . . . 36

Table 7.1 Petroleum Product Imports by Type, Selected Years 1955-1997 . . . . . . . . . . . . . . . . . . . 48

\section{Figures}

Figure 1.1 Petroleum Products and Uses $(1997$ Percent Refinery Yield $) \ldots \ldots \ldots \ldots \ldots \ldots \ldots \ldots$

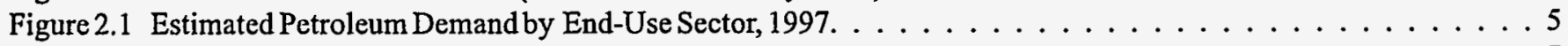

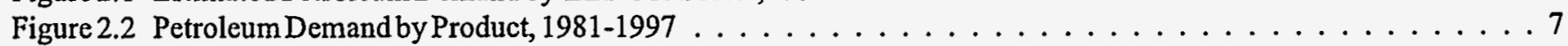

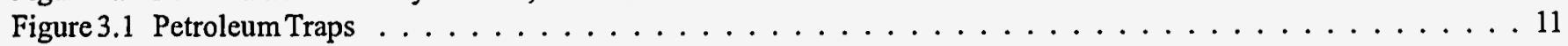

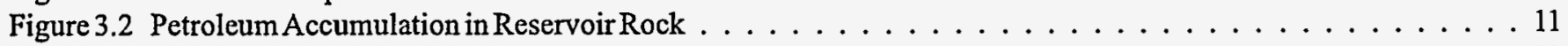

Figure 3.3 U.S. Crude Oil Production versus Additions to Reserves, $1987-1997 \ldots \ldots \ldots \ldots \ldots \ldots$. . . . . . . . . . 12

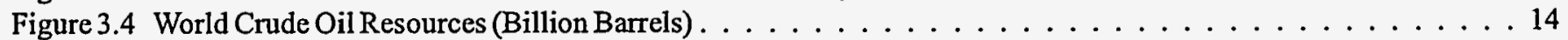

Figure 3.5 Estimated Reserves of Crude Oil by Nation, as of January $1,1997 \ldots \ldots \ldots \ldots \ldots \ldots$

Figure 4.1 World Crude Production in 1997 (Million Barrels per Day). . . . . . . . . . . . . . . . . . . 17

Figure 4.2 Onshore and Offshore U.S. Crude Oil Production, $1970-1997 \ldots \ldots \ldots \ldots \ldots \ldots \ldots$. . . . . . . . . . 18

Figure 4.3 Geographic Origins of U.S. Crude Production, $1970-1997 \ldots \ldots \ldots \ldots \ldots$

Figure 4.4 ARotary Drilling System . . . . . . . . . . . . . . . . . . . . . . . . . . 19

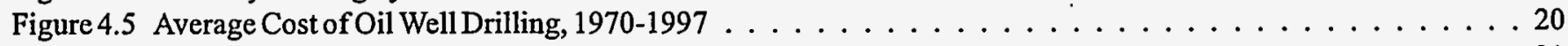

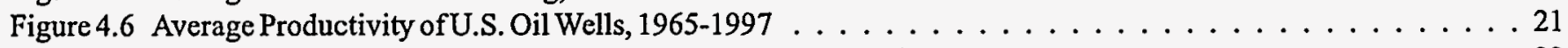

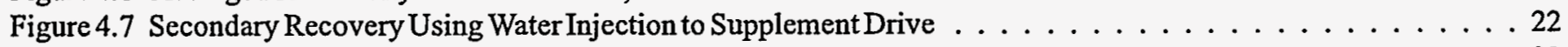

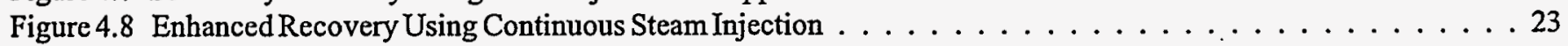

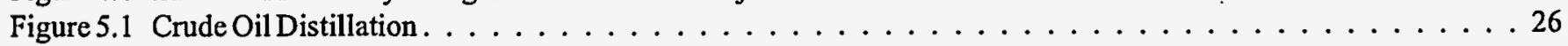

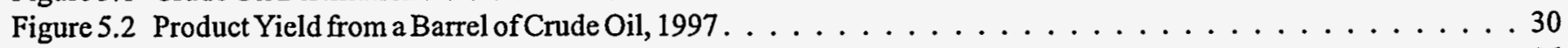

Figure 6.1 Petroleum Transportation by Mode of Travel, Selected Years $1975-1995 \ldots \ldots \ldots$. . . . . . . . . . . . 36

Figure 6.2 Inter-Regional Movement of Crude Oil and Petroleum Products by Water and Pipeline, $1997 \ldots \ldots \ldots$. . . . . . 37

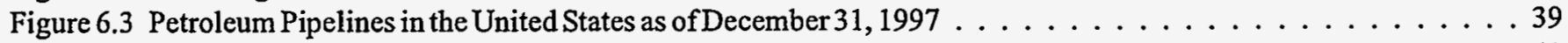

Figure 6.4 U.S. Crude Oil Stocks by Storage Facility, December 31, 1997 . . . . . . . . . . . . . . . . . . . 41

Figure 6.5 Stocks of Major Petroleum Products by Storage Facility, December $31,1997 \ldots \ldots \ldots$. . . . . . . . 41

Figure 6.6 U.S. Stocks of Crude Oil and Petroleum Products, End of Year 1949-1997 . . . . . . . . . . . . . . . 43 
Figure 7.1 Petroleum Flow, 1997. . . . . . . . . . . . . . . . . . . . . 46

Figure 7.2 U.S. Petroleum Imports by Source, $1980-1997 \ldots \ldots \ldots \ldots \ldots \ldots$

Figure 7.3 Sources of U.S. Crude Oil Imports, $1997 \ldots \ldots \ldots \ldots \ldots \ldots$

Figure 7.4 U.S. Petroleum Exports by Destination, $1997 \ldots \ldots \ldots \ldots \ldots \ldots \ldots$

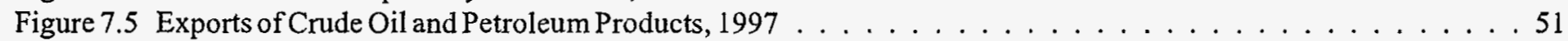

Figure 8.1 Critical Petroleum-Related Events and U.S. Crude Oil Refiner Acquisition Costs, 1970-1997 . . . . . . . . . . 54

Figure 8.2 Simplified Gasoline Market Structure . . . . . . . . . . . . . . . . . . . . 57

Figure 8.3 Components of Retail Regular Gasoline Prices, $1997 \ldots \ldots \ldots \ldots \ldots \ldots \ldots$

Figure 8.4 Prices of Crude Oil and Retail Regular Motor Gasoline, $1970-1997$. . . . . . . . . . . . . . . . . . . 59 


\section{Introduction}

Petroleum has become so interwoven in the daily lives of Americans over the past century that it now comprises an industry which accounts for about 40 percent of all energy consumed in the United States. Americans use petroleum, directly or indirectly, in many applications including transportation fuel, light, heat, and for use in the manufacture of consumer products. Daily per capita consumption of petroleum products in the United States averages nearly 3 gallons-more than one-fourth of the petroleum consumed worldwide.

Petroleum is a complex mixture of liquid hydrocarbon-chemical compounds containing hydrogen and carbon--occurring naturally within the earth. ${ }^{1}$ Early use of petroleum dates back many years. Man first became aware of its existence when it was discovered oozing to the surface from natural "seeps." Native Americans used crude oil skimmed from creeks and rivers as a medicinal ointment. In the 1840's and 1850's, an enterprising Pennsylvanian bottled and sold "Pennsylvania Rock Oil" to treat ailments such as rheumatism, gout, and burns. By the time commercial production began in 1859 , oil was demanded more for its ability to produce light, and kerosene for use in lamps was the principal product. At the turn of the century, the advent of the automobile shifted the emphasis to motor gasoline. In the
1930 's and 1940 's, a substantial market for heating oil developed.

Because petroleum in its raw state has limited uses, further processing of crude oil, via petroleum refining, is needed to unlock the full potential of this resource. In the mid-1800's, the earliest refineries used a distillation process to produce kerosene. Today's refineries employ many processes from simple distillation to the more complex "cracking" and "reforming" operations to convert crude oil into a wide array of desired products. With approximately 20 percent of the world's crude oil distillation capacity and about 30 percent of the more complex cracking and reforming capacity, the United States leads the world in the production of petroleum products. Moreover, motor gasoline alone accounts for about one-half of all U.S. refinery production. (Figure 1.1).

Although petroleum provides many useful products, the most notable are motor gasoline and heating fuel. Petroleum's many uses in the transportation sector include fuel for automobiles, trucks, agricultural and industrial machinery, trains, ships, and aircraft. Petroleum is used to heat homes, offices, and factories and is used to grow, process, package, distribute, refrigerate, and cook food. Petroleum is also the source of synthetic fabric for cloths as well as detergents and

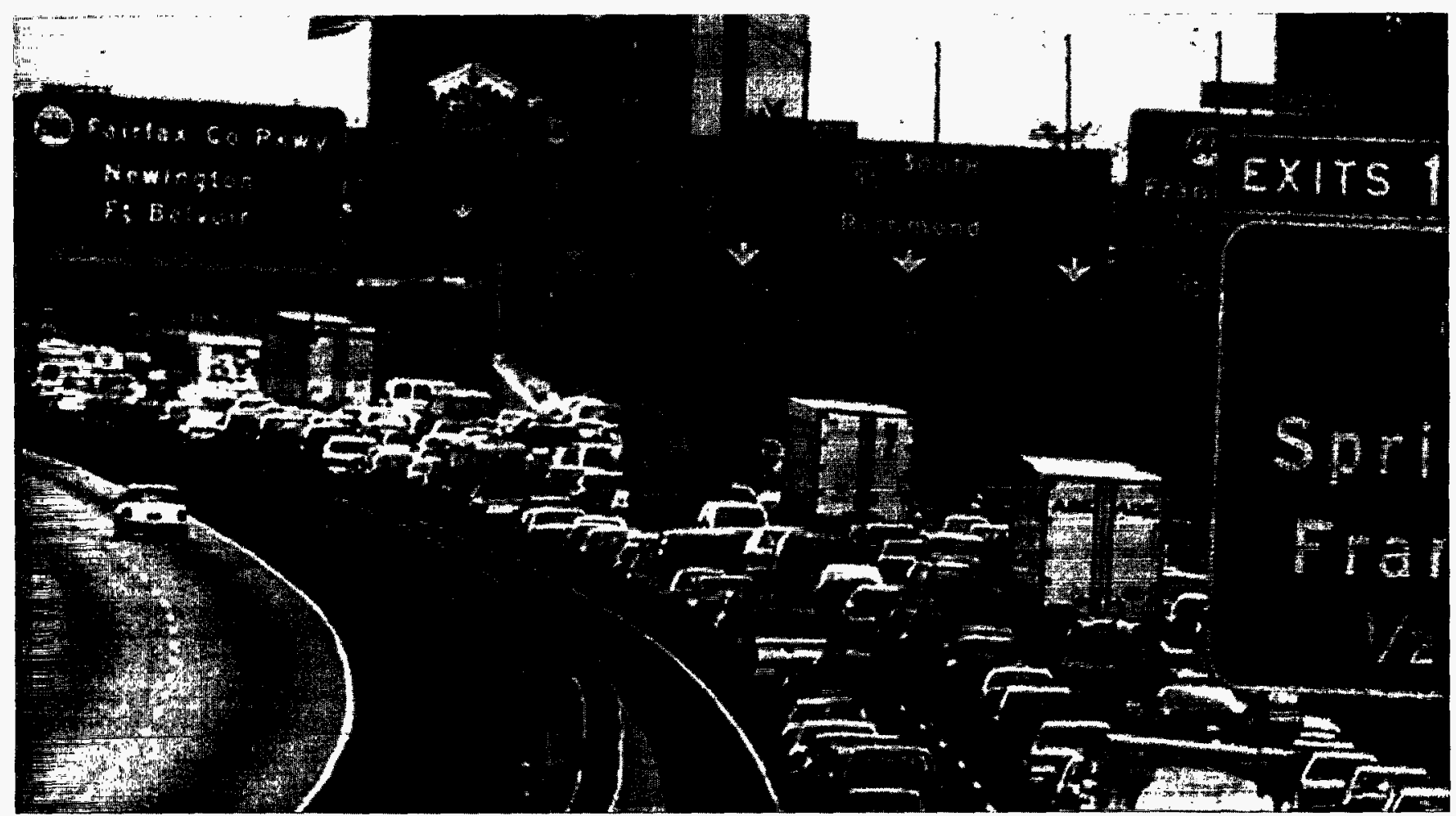

Automobiles, trucks, and buses are fueled mostly by motor gasoline and diesel fuel.

1 Hydrocarbons are found under the earth's surface in both gascous and liquid form. "Natural gas" refers to hydrocarbons occurring in the gaseous state; "petroleum" refers to liquid hydrocarbons: crude oil (Chapter 3), natural gas liquids recovered from natural gas in gas processing plants (Chapter $5)$, and the products they yicld through refining (Chapter 5). 
Figure 1.1 Petroleum Products and Uses (1997 Percent Refinery Yield)

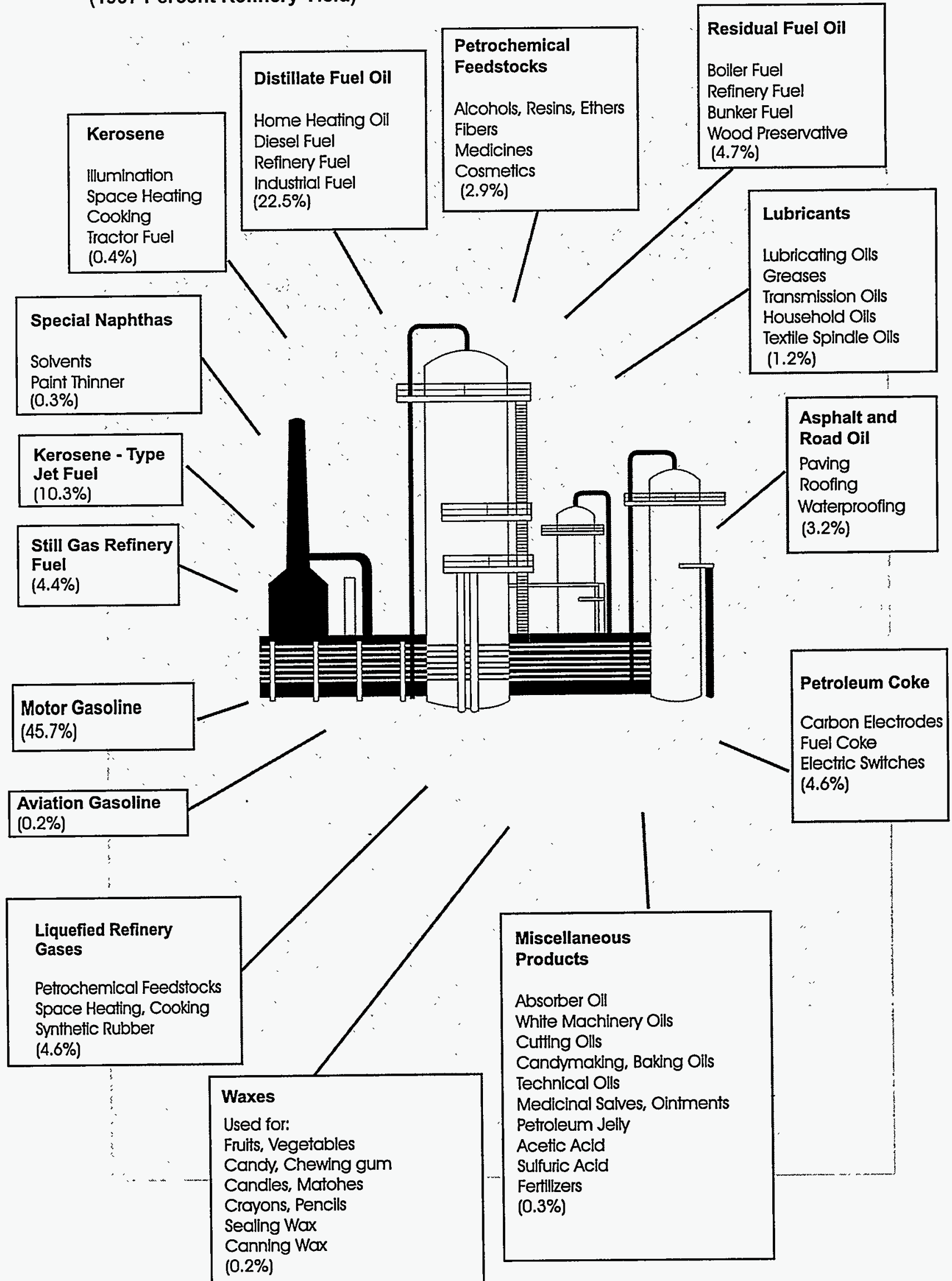

Note: Refinery yield represents the percent of finished product produced at U.S. refineries from input of crude oil and net input of unfinished oils. Components do not add to 100 percent because of processing gain (an increase in volume that occurs during refining). 
dry cleaning solvent to clean them. Moreover, petroleum provides a chemical base for cosmetics and pharmaceutical products as well as for many plastic products from toys to building materials.

The United States consumes more energy from petroleum than from any other energy source. Petroleum provides nearly two-thirds more energy than natural gas, nearly three-fourths more energy than coal, and more than three times the energy from all other energy resources. Although the United States is one of the largest petroleum producers, it actually consumes more than it produces, requiring net imports of crude oil to meet demand.

Growing U.S. petroleum product demand and declining domestic crude oil production have combined to make the United States increasingly dependent on crude oil imports. From its peak of 9.6 million barrels per day in 1970, domestic crude oil production had declined by nearly one-third to 6.5 million barrels per day by 1997 . During this same period, petroleum demand grew by one-fourth, from 14.7 million barrels per day in 1970, to over 18.6 million barrels per day by 1997. Consequently, net imports ${ }^{2}$ of crude oil and products rose from 3.2 million barrels per day in 1970 , to 9.2 million barrels per day by 1997 , causing U.S. dependence on petroleum net imports to grow from about one-fifth in 1970, to nearly half by 1997 .

While crude oil production is declining in the United States, so are proved reserves of crude oil. The U.S. holds about a 2 percent share of the world's crude oil reserves. As world reserves are depleted, the roles of Saudi Arabia and other Middle East suppliers are increasingly important in international petroleum supply. This was dramatically illustrated by fears of worldwide supply disruption following Iraq's invasion of Kuwait in August 1990.

A vast transportation network of tankers, barges, pipelines, railways, and trucks moves crude oil from the field to refineries, where it is processed, and brings refined products to the consumer. This complex system also links foreign suppliers to domestic customers and provides access to foreign markets for products from U.S. refineries.

Storage facilities hold crude oil and refined products at various stages as they move through the system. Marine terminals receive crude oil as it is unloaded from tankers and hold it until it is transported by pipeline or other means to the refinery for processing. When it reaches the refinery, it is stored again until it can be processed. After processing, the refined products go to bulk terminals where they are stored until they are transferred to retail sales outlets and the final consumer. Above-ground tanks, underground caverns and tanks, and offshore storage are used to hold supplies of crude oil and petroleum products as they move through the distribution system. The largest underground storage facilities are part of the U.S. Strategic Petroleum Reserve, containing petroleum stocks maintained by the Federal Government for use during periods of major supply disruptions.

The petroleum industry can be divided into two main sectors that are largely functional in nature: the upstream sector that includes exploration and production and the downstream sector which includes refining, transportation, and marketing. The industry is highly integrated, with many firms involved in more than one sector. Large companies known as "majors" are fully integrated and may own and operate establishments involved in all of these sectors. Smaller, nonintegrated companies often referred to as "independents" generally specialize in one aspect, such as crude oil exploration and production or product marketing. The petroleum industry is international in scope, and it has a complex system of markets where exchanges, long- and short-term sales contracts, and spot market and futures contracts are used to transfer oil ownership as it passes from one sector to the next. The following chapters discuss the role of petroleum products in our society and describe the workings of the U.S. petroleum supply network-from the petroleum resource base through crude oil exploration and production, refining, transportation and storage, product marketing, and distribution.

For the most recent data on refinery yields and petroleum supply and demand, look for the current issues of the Weekly Petroleum Status Report and the Petroleum Supply Monthly on the "Petroleum" page of EIA's website at http://www.eia.doe.gov/. For the most recent data and historical data on U.S. energy consumption, see the Monthly Energy Review and the Annual Energy Review on the "Historical" page of our website. 



\section{Petroleum Products}

We find petroleum products in every area of our lives. They are easily recognized in the gasoline we use to fuel our cars and the heating oil we use to warm our homes. Less obvious are the uses of petroleum-based components of plastics, medicines, food items, and a host of other products. Petroleum products fall into three major categories: fuels such as motor gasoline and distillate fuel oil (diesel fuel); finished nonfuel products such as solvents and lubricating oils; and feedstocks for the petrochemical industry such as naphtha and various refinery gases. Demand is greatest for products in the fuels category, especially motor gasoline.

Petroleum products contribute about 40 percent of the energy used in the United States. This is a larger share than any other energy source including natural gas with a 25 percent share, coal with about a 23 percent share, and the combination of nuclear, hydroelectric, geothermal and other sources comprising the remaining 12 percent share. ${ }^{1}$ It is projected that petroleum consumption in the United States will increase by 1.2 percent annually, reaching 24.7 million barrels per day by the year $2020 .^{2}$ Although petroleum consumption will continue to increase overall, its share of total energy use has shrunk over the past several decades as a result of conservation efforts, fucl efficiency improvements, and growing use of alternative sources of energy. While petroleum will undoubtedly remain the Nation's leading energy source for some time, the need to balance environmental, economic, and energy security objectives has led policy-makers and planners to seek means of diversifying the sources and reducing the role of this resource in our overall energy supply. ${ }^{3}$

Petroleum products, especially motor gasoline, distillate (diesel) fuel, and jet fuel, provide virtually all of the energy consumed in the transportation sector. Transportation is the greatest single use of petroleum, accounting for an estimated 66 percent of all U.S. petroleum consumed in 1997 (Figure 2.1). The industrial sector is the second largest petroleum consuming sector and accounts for about 26 percent of all petroleum consumption in the United States. Residential/Commercial and the electric utility sectors account for the remaining 8 percent of petroleum consumption. ${ }^{4}$

Demand for petroleum products ${ }^{5}$ in the United States averaged 18.6 million barrels per day in 1997. This represents about 3 gallons of petroleum each day for every person in the country. By comparison, petroleum demand averaged about
Figure 2.1 Estimated Petroleum Demand by End-Use Sector, 1997

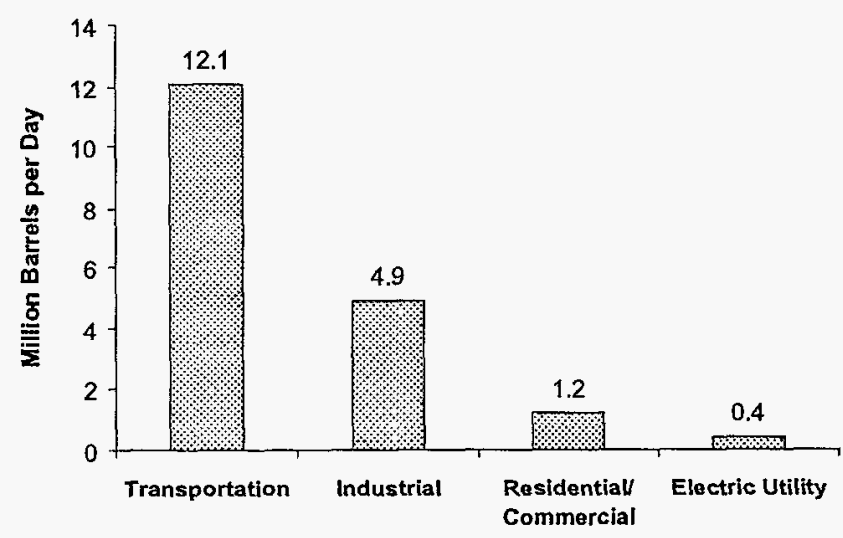

Source: Energy Information Administration, Annual Energy Review 1997, DOE/EIA-0384, Tables 5.12a and 5.12b.

2 gallons per person per day in the early 1950's and nearly 3.6 gallons per person per day at its peak in 1978 .

Price levels, economic growth trends, and weather conditions influence the demand for petroleum products. For example, oil prices affect a consumer's willingness to use petroleum instead of other fuels such as natural gas. High prices relative to other fuels tend to encourage fuelswitching, especially at electric utilities, in industrial plants having dual-fuel boilers, and in households that have woodburning stoves and electric heaters available. ${ }^{6}$ High prices also provide incentive for individuals to adopt short-term conservation measures, such as adjusting thermostats and reducing discretionary driving. High prices stimulate longterm measures as well, such as design changes that increase fuel efficiency in automobiles, improved insulation in newly constructed and existing buildings, and design changes in appliances to improve energy efficiency. Once in place, these long-term conservation measures continue to affect fuel use regardless of subsequent price fluctuations.

Low oil prices tend to stimulate demand. Demand also increases during periods of economic expansion, particularly in the industrial and transportation sectors, as increases in the production of goods bring corresponding increases in transportation of raw materials and deliveries of finished prod-

1 Energy Information Administration, Monthly Energy Review, March 1999, DOE/EIA-0035(99/03), Table 1.4.

2 Energy Information Administration, Annual Energy Outlook 1999, DOE/EIA-0383(99), Table A11.

3 U.S. Department of Energy, National Energy Strategy, DOE/S-0124, April 1998, p. 16.

4 Energy Information Administration, Monthly Energy Review, April 1999, DOE/EIA-0035(99/04), Tables 1.4, 2.3, 2.4, 2.5 and 2.6.

5 Petroleum demand is measured when petroleum products become available, or "supplied" for domestic consumption as reported in the Petroleum Supply Annual DOE/EIA-0340; "end use consumption" refers to estimates published in the State Energy Data Report, DOE/EIA-0214, and the Monthly Energy Review, DOE/EIA-0035.

- Energy Information Administration, Estimates of Short-Term Petroleum Fuel Switching Capability, DOE/EIA-0526, June 1989, p.iv. 


\section{End-Use Sectors}

The following are the major economic sectors to which consumption is allocated in this report.

Residential Sector. Private hauseholds that consume energy primanily for spaceleating, water heating, ari conditioning, refrigeration, cooking, and clothes drying.

Cammercial Sector. Non-manufacturing or non-transportation business establishiments inchuding hotels, motels, restaurants, wholesale businesses, retal stotes, laundres, and other service enterprises, health, social, and edurational institutions; religious and nonprofit orgatrizations, and Federaf, State, and focal government institutions; : Street lights; pumps, bridges, and public services are included.

Industrial Sector, Manufacturing, construction, mining, agricuturey fishing, and forestry establishiments

Transportation Sector. Priyate and public vehicles that move people and conmonodities. Inctudes automobiles; trucks; : buses, motorcycles, railroads and rallways (incluđing streetcars), aircraft, ships, barges, and natural gas pipelines.

Electric Utility Sector. Privatëly and publicly owned establishments that genetate transmit distribute or sell electricity :.: primarily for use by the public. Nonutility power producers are not indited in the electric utility sector.

ucts. Lower prices coupled with economic expansion stimulated consumption during periods in the mid-1980's and mid-1990's.

Weather extremes (winters that are colder than normal or summers that are warmer than normal) also increase petroleum demand for heating or electricity generation for airconditioning purposes. Milder weather than normal tends to reduce heating and air conditioning-related demand for petroleum fuels. Weather can also contribute to the seasonal variations in demand for transportation fuels such as gasoline.

Petroleum demand illustrated the effects of these factors several times during the 1990's. For instance, the Iraqi invasion of Kuwait on August 2, 1990, caused petroleum demand to sink to under 17 million barrels per day, its lowest level since 1987. The slowing economy and mild weather had weakened demand early in the year. Then, following the invasion, prices climbed rapidly in response to uncertainty over future supplies, with motor gasoline and jet fuel prices registering dramatic increases. Shortly after the United Nations Security Council approved an embargo against oil exports from Iraq and Kuwait, the Organization of Petroleum Exporting Countries (OPEC) adopted a resolution allowing member countries to exceed their production quotas to make up the difference. As production increases from OPEC and other countries began to offset the loss of Iraqi and Kuwaiti oil, petroleum prices subsided.

\section{Petroleum Fuels}

Fuel products account for nearly 9 out of every 10 barrels of petroleum used in the United States. The leading fuel, motor gasoline, consistently accounts for the largest share of petroleum demand (Figure 2.2). Demand for motor gasoline alone accounts for more than 40 percent of the total demand for petroleum products. Other petroleum fuels include distillate fuel oil (diesel fuel and heating oil), liquefied petroleum gases (LPG's)(including propane and butane), jet fuel, residual fuel oil, kerosene, aviation gasoline, and petroleum coke.

Motor gasoline is chiefly used to fuel automobiles and light trucks for highway use. Smaller quantities are used for offhighway driving, boats, recreational vehicles, and various farm and other equipment.

A number of factors influence the demand for motor gasoline. For example, rising gasoline prices in the 1970's encouraged consumers to reduce discretionary driving and stimulated consumer demand for smaller, more fuel efficient automobiles. The Corporate Average Fuel Economy (CAFE) Standards established by the Energy Policy and Conservation Act of 1975 set mileage standards for new cars that helped reduce gasoline demand even more as new, more fuel efficient cars replaced older, less efficient cars. The effects of the market shift to smaller cars and the fuel efficiencies resulting from the CAFE standards continued to restrain growth in gasoline demand through the 1980's. However, by the mid-1990's, fuel efficiency growth slowed considerably as low gasoline prices and rising disposable income spurred consumers to buy less fuel efficient light trucks, vans, and sport utility vehicles.

Environmental concerns have brought about a number of changes in gasoline composition. To meet emission standards specified in the Clean Air Act of 1970, automobile manufacturers introduced catalytic converters requiring unleaded fuel beginning in the 1975 model year. The Environmental Protection Agency (EPA) issued regulations in 1973 


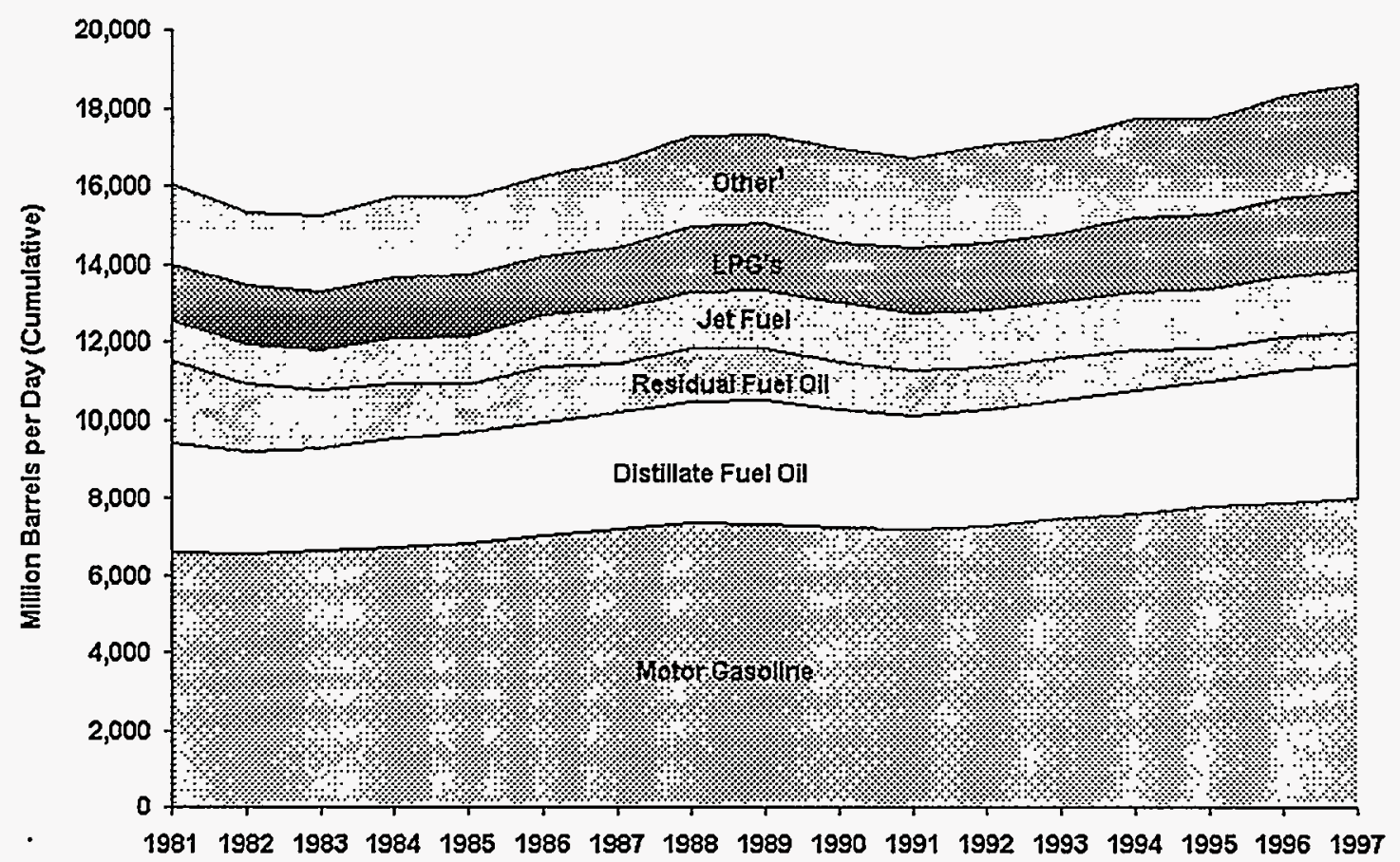

\footnotetext{
${ }^{1}$ Includes still gas, asphalt and road oil, petrochemical feedstocks, petroleum coke, lubricants, pentanes plus, kerosene, special naphtha, aviation gasoline, waxes miscellaneous products, and crude oil.

Sources: Energy Information Administration, Petroleum Supply Annual 1997, DOE/EIA-0340(97)/1.
}

establishing requirements for the availability of unleaded fuels and, as the new cars entered the fleet, unleaded gasoline began to displace leaded fuel. EPA continued the lead phase-down, further restricting the lead content of motor gasoline in 1982, 1985, and 1986. The Clean Air Act Amendments of 1990 banned lead use entirely, effective January $1,1996$.

As lead was eliminated, the use of other components, such as butane, aromatics, alcohols, and ethers, to boost gasoline octane increased. Some of these additives like butane increase the volatility, or evaporative tendency, of gasoline. As gasoline evaporates, contaminants are released into the atmosphere. EPA and several States have issued regulations to restrict gasoline volatility in the summer months when the problem is more severe. Federal regulations restricting gasoline volatility took effect in 1989 . Several States and localities have also begun to require the use of other additives termed "oxygenates" in gasoline to reduce carbon monoxide emission levels during the wintertime. These restrictions and proposals to amend the Clean Air Act encouraged the industry to develop and market new "reformulated" gasolines. The Clean Air Act Amendments of 1990 set standards for reformulated gasoline and mandated its use in several U.S. cities beginning in 1995.
Anumber of "alternative" fuels have been developed for automotive use. Methanol (an alcohol produced from natural gas, coal, or biomass) and ethanol (an alcohol produced from biomass) are two alternative fuels that may be viewed as potential replacements for petroleum products or as additives for use in present or future gasoline formulations. ${ }^{7} \mathrm{Com}$ pressed natural gas, electricity, propane, liquefied natural gas, hydrogen, and solar energy are other transportation fuel alternatives under consideration and in various stages of development.

Distillate fuel oil includes diesel oil, heating oils, and industrial oils. It is used to power diesel engines in buses, trucks, trains, automobiles, and other machinery. It is also used to heat residential and commercial buildings and to fire industrial and electric utility boilers. Specifications differ for heating oils and diesel fuels based primarily on the sulfur content of each fuel.

Diesel fuel accounts for about three-fourths of refinery first sales of distillate fuel oils. ${ }^{8}$ Most diesel fuel is used for transportation purposes: highway diesel fuel represents more than half of distillate fuel sales. Residential heating, the next largest end-use category, represents about 12 percent of annual distillate use, but is concentrated in the winter months.

7 Methanol can be used alone as an alternative fuel, know as "M100." It can also be used as a component of the mixture of 85 percent methanol and 15 percent gasoline known as "M85." Methanol is also used to produce methyl tertiary butyl ether (MTBE), an oxygenate used in reformulated gasoline. Ethanol can also be used alone as a transportation fuel, but is generally blended with gasoline. It can also be used to produce ethyl tertiary butyl ether (ETBE), another oxygenate.

8 Energy Information Administration, Petroleum Marketing Annual 1997, December 1998, DOE/EIA-0487(97) Table 50.

9 Energy Information Administration, Fuel Oil and Kerosene Sales 1997, DOE/EIA-0535(97), Table HL1. 
Environmental concerns also extended to diesel fuel. The Clean Air Act Amendments of 1990 mandated standards, effective October 1, 1993, for diesel fuels designated for on-highway use to a maximum sulfur content of 0.05 percent by weight.

Liquefied petroleum gases (LPG's) rank third in usage among petroleum products, behind motor gasoline and distillate fuel oil. LPG's are used as inputs (feedstocks) for petrochemical production processes. This is their major nonfuel use. LPG's are also used as fuel for domestic heating and cooking, farming operations, and as an alternative to gasoline for use in internal combustion engines.

Individual LPG products (see Glossary) have distinct uses. For example, propane is widely used as a fuel in the residential, commercial, and industrial sectors. It is also important as a petrochemical feedstock. Ethane is used primarily as a petrochemical feedstock. Butane is used as a gasoline blending component, although volatility regulations for gasoline have limited its use for this purpose (see Chapter 5). Butane also has many domestic and industrial uses.

Most jet fuel is a kerosene-based fuel primarily used in commercial airlines. It requires a higher temperature to ignite and is safer for commercial use than naphtha-based fuel. Naphtha jet fuel meets the specifications required for certain military aircraft. It has a lower freezing point than commercial fuel and a lower flash (ignition) point. However, from October 1, 1993, through 1995, the U.S. military essentially converted most of its jet fleet from naphtha-type jet fuel to kerosene-type jet fuel.

Kerosene-type jet fuel is sometimes blended into heating oil and diesel fuel during periods of extreme cold weather. This is done to help alleviate viscosity (thickness), handling and performance problems associated with cold weather.

Electric utilities use residual fuel to generate electricity. Although this sector uses relatively little petroleum compared with the transportation and industrial sectors, the electric utility sector depends on petroleum for about 5 percent of its total energy requirements. Much of the surplus capacity for electricity generation is oil-fired, so petroleum use by utilities is expected to increase along with electricity demand. Residual fuel oil is also used as bunker fuel (fuel for ships), industrial boiler fuel, and heating fuel in some commercial buildings.

Kerosene is used for residential and commercial space heating. It is also used in water heaters, as a cooking fuel, and in lamps. Kerosene falls within the light distillate range of refinery output that includes some diesel fuel, jet fuel, and other light fuel oils.

Petroleum coke can be used as a relatively low-ash solid fuel for power plants and industrial use (marketable coke) if its sulfur content is low enough, or used in nonfuel applications (catalyst coke), such as in refinery operations.

\section{Nonfuel Products}

Nonfuel use of petroleum is small compared with fuel use, but petroleum products account for about 89 percent of the Nation's total energy consumption for nonfuel uses. There are many nonfuel uses for petroleum, including various specialized products for use in the textile, metallurgical, electri$\mathrm{cal}$, and other industries. A partial list of nonfuel uses for petroleum includes:

- Solvents such as those used in paints, lacquers, and printing inks

- Lubricating oils and greases for automobile engines and other machinery

- Petroleum (or paraffin) wax used in candy making, packaging, candles, matches, and polishes

- Petrolatum (petroleum jelly) sometimes blended with paraffin wax in medical products and toiletries

- Asphalt used to pave roads and airfields, to surface canals and reservoirs, and to make roofing materials and floor coverings

- Petroleum coke used as a raw material for many carbon and graphite products, including furnace electrodes and liners, and the anodes used in the production of aluminum.

- Petroleum Feedstocks used as chemical feedstock derived from petroleum principally for the manufacture of chemicals, synthetic rubber, and a variety of plastics.

\section{Petrochemical Feedstocks}

Petroleum feedstocks have been used in the commercial production of petrochemicals since the 1920's. Petrochemical feedstocks are converted to basic chemical building blocks and intermediates used to produce plastics, synthetic rubber, synthetic fibers, drugs, and detergents. Naphtha, one of the basic feedstocks, is a liquid obtained from the refining of crude oil.

Petrochemical feedstocks also include products recovered from natural gas, and refinery gases (ethane, propane, and butane). Still other feedstocks include ethylene, propylene, normal- and iso-butylenes, butadiene, and aromatics such as benzene, toluene, and xylene. These feedstocks are pro- 
duced by processing products such as ethane (separated from natural gas), distillates, naphthas, and heavier oils.

Industry data show that the chemical industry uses nearly 1.5 million barrels per day of natural gas liquids and liquefied refinery gases as petrochemical feedstocks and plant fuel. ${ }^{10}$
Demand for textiles, explosives, elastomers, plastics, drugs, and synthetic rubber during World War II increased the petrochemical use of refinery gases. Gas byproducts from the production of gasoline are an important source of many feedstocks.

For the most recent data on petroleum supply and demand, look for the current issues of the Weekly Petroleum Status Report and the Petroleum Supply Monthly on the "Petroleum" page of EIA's website at http://www.eia.doe.gov/. Sales volumes for petroleum products are in the Petroleum Marketing Monthly, also on the "Petroleum" page. For the most recent data and historical data on U.S. energy consumption by fuel type and end-use sector, see the current issues of the Monthly Energy Review and the Annual Energy Review on the "Historical" page of our website.

10 American Petroleum Institute, 1996, Sales of Natural Gas Liquids and Liquefied Refinery Gases, October 1997, Table 1. 


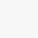




\section{Petroleum Resources and Reserves}

The most widely accepted explanation of how oil was formed within the earth is the biological, or organic, theory which asserts that hydrocarbons were created from the remains of once-living organisms. ${ }^{1}$ The biological process is believed to have begun millions of years ago when the remains of microscopic marine plants and animals settled at the bottom of bodies of water. As time passed, more layers of remains and inorganic materials, such as sand and clay-rich mud, settled on top. Pressure, dehydration and cementation compacted the inorganic particles, forming them into sedimentary rock. Temperatures rose as a result of the geothermal gradient within the earth. The organic material composed of carbon, hydrogen, oxygen, and other elements -reacted to the heat, pressure, and bacteria action. The original chemical bonds were broken and the elements were reformed into hydrocarbons and other compounds, mainly water and carbon dioxide.

Over time, oil migrated from the formations where it was created (the source rocks) to more porous rock. Migration, generally upward, stops only when oil finally seeps out of the ground or encounters a trap inside the earth. ${ }^{2}$ A trap is a barrier to the upward movement of oil, often a rock formation so dense that oil cannot penetrate it. Anticlines, faults, and salt domes are common trapping structures (Figure 3.1). Movements or shifts inside the earth can cause rock layers to fold upward forming an anticline or to break along a fault line. An impenetrable rock layer lying over an oil-bearing layer can trap oil inside the hill-shaped structure of an anticline. Along a fault line, a porous oil-bearing layer may be shifted next to a nonpourous layer, trapping oil there. A salt dome is formed by the upward movement of a large underground deposit of solid salt remaining from ancient shallow seas. Because oil cannot penetrate salt, it is often found trapped in the sediments layers tilted up around the sides of salt domes. In fact, early drillers who sank wells near salt domes to extract brine for preserving meat and other foods were often dismayed to find oil coming up with and contaminating their brine.

The rock formation where oil collects beneath a trap is known as a reservoir. Oil, usually together with natural gas and salt water, resides in tiny pore spaces between the grains, or in the fractures, of the reservoir rock (Figure 3.2). One or more reservoirs related to the same geological feature are known as a field. The most common types of rock found to contain oil are sandstone, limestone, and dolomite.

Each reservoir has unique characteristics which determine how much of the oil residing there can ultimately be extracted and what techniques are required to bring the oil up
Figure 3.1 Petroleum Traps

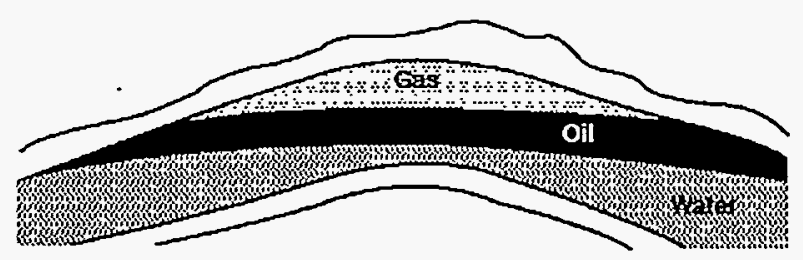

Anticline

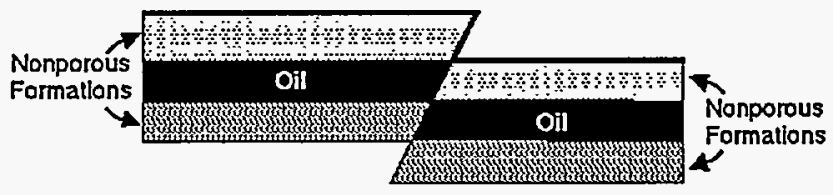

Fault

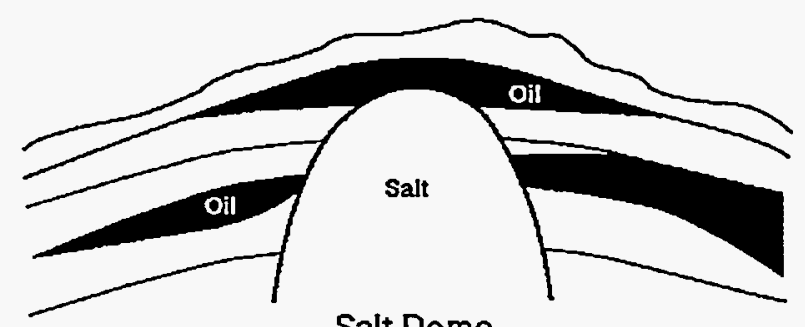

Salt Dome

Source: Energy Information Administration, Office of Oil and Gas.

Figure 3.2 Petroleum Accumulation in Reservoir
Rock

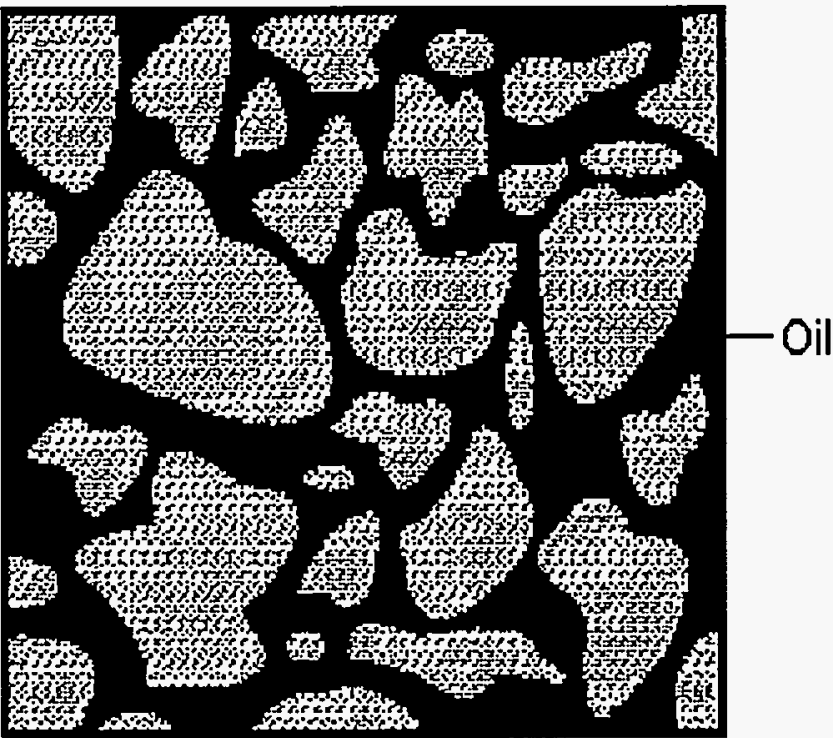

Source: Energy Information Administration, Office of Oil and Gas.

1 A few scientists believe that hydrocarbons were generated during the earth's creation, from the same inorganic materials which formed the earth, and have been slowly seeping out of the earth's center since. Acceptance of this "abiogenic theory" of petroleum formation, however, is not widespread. 2 Slippery Rock Creek, Pennsylvania was named after a rocky area of a creek into which oil naturally seeped. Early oil fields were often found by drilling near existing oil seeps. 
from the reservoir. Two of the most important characteristics are porosity and permeability. Porosity refers to the amount of pore space in the rock and permeability refers to the ability of a liquid to flow through the rock from pore to pore, pore to fracture, or fracture to fracture. A formation with high porosity can hold more oil in a given volume of rock. If a reservoir has many large connections between the pore spaces, it has good permeability.

The total quantity of oil which is trapped within the boundaries of a reservoir or field make up its total oil resources. Total world oil resources include all the oil ever generated inside the earth and trapped there. The amount of total resources in the world, or in any particular field, is uncertain. Estimates of oil resources, by field and by nation, are routinely made using information from geologists and engineers who measure the porosity and permeability of rock formations, construct geological maps, estimate the extent and thickness of formations suspected or known to contain oil, and compile many other types of data. These estimates are continually revised as more knowledge becomes available.

A portion of the world's oil resources will never be recovered from the earth because of physical, technological, or economic constraints. For example, the recovery of oil from some reservoirs that are very difficult to reach or that contain extremely small amounts of oil, would consume more energy than the recovered oil would ultimately yield. Also, even though recovery techniques have improved over time, current methods do not enable producers to extract all the oil from developed fields. Of those resources which are recoverable, only a portion have already been discovered; others are thought to exist in favorable geologic settings but are, as yet, undiscovered. Resources which have already been discovered and produced are referred to as cumulative production. Recoverable resources which remain to be produced are referred to as reserves. Those reserves which are expected to be recoverable in the future under existing technological and economic conditions are known as proved reserves.

When new fields or reservoirs containing oil are discovered or when known reservoirs are extended by drilling additional wells, proved reserves increase. When oil is removed from a reservoir by production, proved reserves decrease. If new information on a reservoir's characteristics becomes available and indicates there is more or less oil trapped there than originally thought, proved reserves estimates are revised up or down accordingly. Because of the way proved reserves are defined, changes in the economy, especially the price of crude oil or operating conditions or technology can also increase or decrease proved reserves. Proved ultimate recovery is the sum of the estimate of proved reserves at a specific time and cumulative production up to that time.

\section{U.S. and World Reserves}

A major increase in U.S. proved reserves occurred in 1970 when newly discovered oil in Alaska was added to the estimates of proved reserves. ${ }^{3}$ Since then, U.S. proved reserves have declined overall as there have been few major oil discoveries and the rate of production has generally exceeded

\section{Figure 3.3 U. S. Crude Oil Production versus Additions to Reserves, 1987-1997}

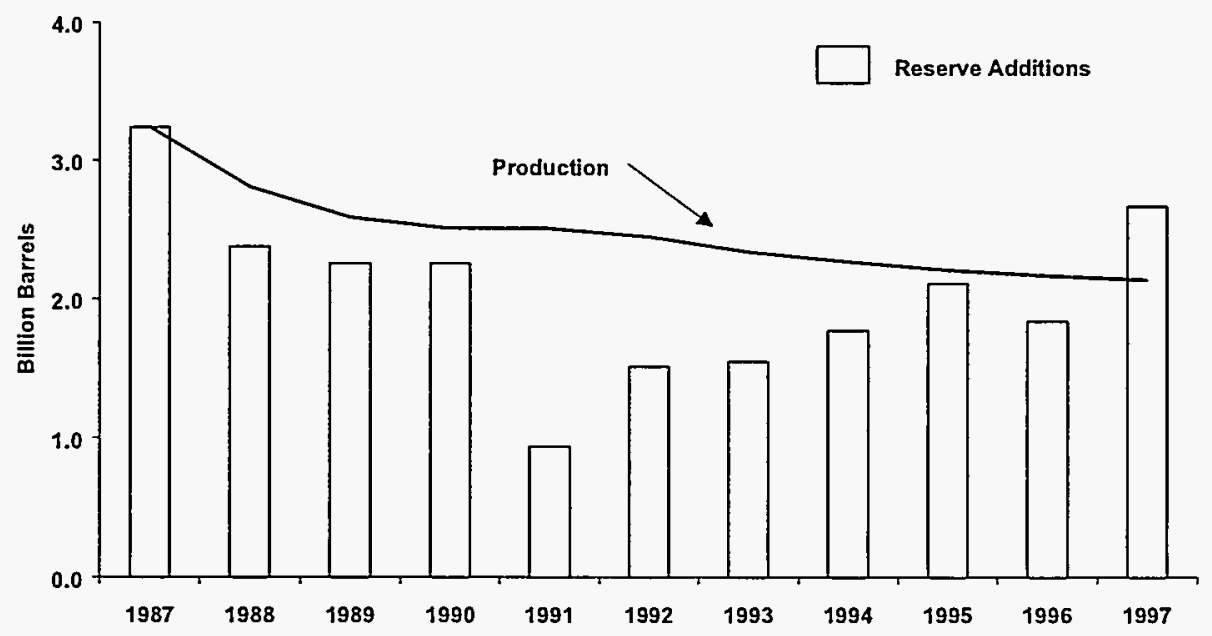

Note: Production estimates are based on data reported on Form EIA-23 and do not include estimates for lease condensate. Thus, they differ from the crude oil production data contained in the Petroleum Supply Annual.

Source: Energy Information Administration, U.S. Crude Oil, Natural Gas, and Natural Gas Liquids Reserves 1997 Annual Report, DOE/EIA-0216(97)

3 Several years often elapse between the time a field is discovered and the time its resources are determined to be proved reserves. 
Table 3.1 Ten Largest Oil Fields in the United States ${ }^{1}$ as of January 1, 1999

\begin{tabular}{|c|c|c|c|c|c|}
\hline Oil Field & Location & $\begin{array}{c}\text { Year } \\
\text { Discovered }\end{array}$ & $\begin{array}{l}\text { Cumulative } \\
\text { Production }\end{array}$ & $\begin{array}{c}\text { Estimated } \\
\text { Remaining } \\
\text { Reserves }\end{array}$ & $\begin{array}{c}\text { Estimated } \\
\text { Recoverable } \\
\text { Resources }\end{array}$ \\
\hline & & & \multicolumn{3}{|c|}{ (billion barrels) } \\
\hline Prudhoe Bay & Alaska & 1968 & 9.7 & 3.3 & 13.0 \\
\hline East Texas & Texas & 1930 & 5.3 & (s) & 5.4 \\
\hline Wilmington & California & 1932 & 2.5 & 0.3 & 2.8 \\
\hline Midway-Sunset & California & 1894 & 2.4 & 0.3 & 2.7 \\
\hline Kuparuk River & Alaska & 1969 & 1.6 & 1.0 & 2.6 \\
\hline Wasson & Texas & 1936 & 2.0 & 0.1 & 2.1 \\
\hline Kern River & California & 1899 & 1.7 & 0.4 & 2.1 \\
\hline Yates & Texas & 1926 & 1.4 & 0.6 & 2.0 \\
\hline Panhandle & Texas & 1921 & 1.5 & (s) & 1.5 \\
\hline Elk Hills & California & 1911 & 1.1 & 0.3 & 1.4 \\
\hline
\end{tabular}

${ }^{1}$ By size of total recoverable resources.

$(s)=$ less than 100 million barrels.

Note: Total may not equal sum of components due to independent rounding.

Source: PennWell Publishing Company, Oil \& Gas Journal, January 25, 1999, pp. 76-77.

the rate of additions to reserves (Figure 3.3). For the most part, revisions to earlier proved reserves estimates have contributed more than discoveries to reserve additions; that is, drilling in existing fields plus technological advances are finding more oil than wildcat (new field) wells are. While crude oil discoveries increased 33 percent in 1997 over the previous year, revisions to earlier estimates continue to be the most significant factor in moderating the decline in reserves. From 1977 through 1995 approximately 93 percent of the additions to U.S. proved reserves of crude oil were due to proved ultimate recovery appreciation rather than to the discovery of new oil fields. ${ }^{4}$

As of December 31, 1997, it was estimated that the United States had 22.5 billion barrels of proved crude oil reserves and 8.0 billion barrels of proved natural gas liquids reserves. Most of these are located in Texas, Alaska, and California. Texas had an estimated 5.7 billion barrels and Alaska had an estimated 5.2 billion barrels of crude oil proved reserves at the end of 1997, while California had an estimated 3.8 billion barrels. Offshore areas of California, Texas, and Louisiana also contain a large share of proved reserves. Most of the offshore proved crude oil reserves, 2.7 billion barrels of the 3.5 billion-barrel total in 1997, were located in federally controlled waters of the Outer Continental Shelf.

The largest oil field discovered in the United States to date is the Prudhoe Bay Field in northern Alaska. Its ultimately re- coverable resources (cumulative production plus remaining proved reserves) are estimated to be 13 billion barrels of crude oil (Table 3.1). As of January 1, 1999, its remaining proved reserves were estimated to be 3.3 billion barrels. The second largest field in the United States, East Texas, was discovered over 60 years ago; much of its oil has already been produced. Originally estimated to hold 6 billion barrels of recoverable crude oil in total, it is now estimated to have less than 1 billion barrels of remaining proved reserves.

The United States has already developed many of its oil resources. There are other areas of the world where many resources remain to be developed (Figure 3.4). Estimates indicate that the United States has only about 3 percent of the world's remaining recoverable crude oil. Estimates of proved world crude oil reserves at the beginning of 1998 vary between 974 and 1,020 billion barrels. ${ }^{5}$

Most of the world's reserves are located in the Middle East. Saudi Arabia has more crude oil reserves that any other nation. About two-thirds of the world's proved reserves of crude oil are located in countries which belong to the Organization of Petroleum Exporting Countries (OPEC) (See Glossary.) (Figure 3.5).

Although there are relatively few giant oil fields in the world, they ac- 


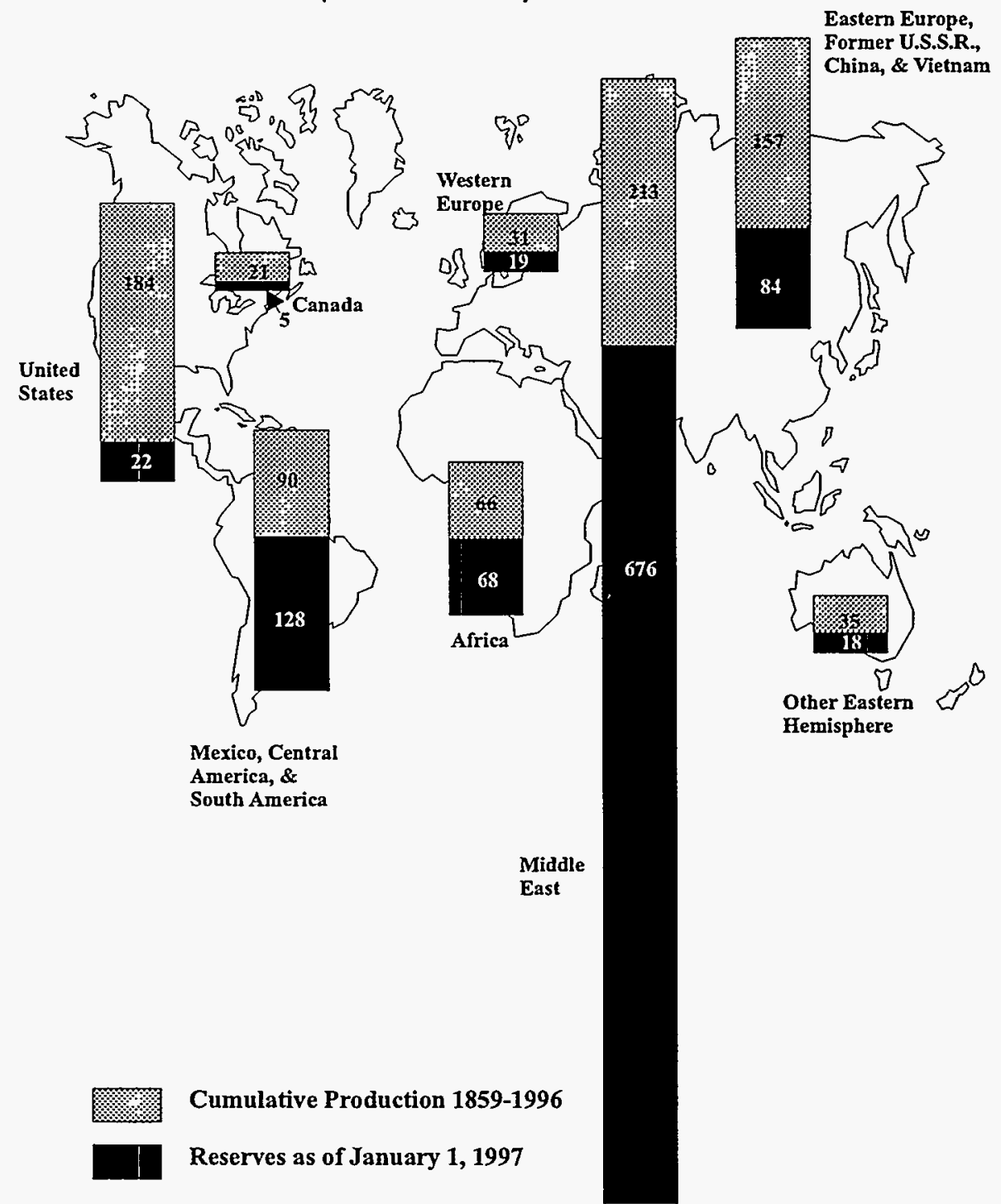

Sources: Cumulative Production 1859-1984: The British Petroleum Company, BP Statistical Review of World Energy, June 1985; Production: 1985-1996: Energy Information Administration, International Energy Annual 1996, and previous reports, Table 2.2; Reserves: Energy Information Administration, International Energy Annual 1996, Table 8.1.

count for most of the world's reserves. ${ }^{6}$ Saudi Arabia has the world's largest known oil field, the Ghawar Field, which was discovered in 1948. Ultimate resources of this field are estimated at 123 billion barrels of recoverable crude oil, of which 48.9 billion barrels have already been produced. ${ }^{7}$ As of 1984 , there were 265 world-scale "giant" oil fields, 18 of which contained 10 billion barrels or more of recoverable resources. $^{8}$

Because most areas of the United States have already been thoroughty explored, the likelihood of finding majornew discoveries is waning. At the end of 1997, however, the United States had 3.2 billion barrels of indicated additional crude oil reserves, which may be reclassified as proved reserves in the future. These reserves, located mostly in central California, western Texas, and Alaska are known crude oil reserves which are believed to be recoverable using current technology, but for which the potential for economic recovery under current conditions is uncertain. They will be added to crude oil reserves if and when production techniques are applied and they prove to be economically practical.

Estimates have also been made of undiscovered resources in the United States. The existence and recoverability of these resources is much less certain than that of proved reserves. It is estimated that in 1995, the United States had 77.9 billion barrels of undiscovered technically recoverable crude oil. ${ }^{9}$ About 60 percent of these undiscovered resources were estimated for areas located offshore on the Outer Continental Shelf.

6 In the United States, the term "giant" usually refers to a field with total recoverable oil resources of 100 million barrels or more and a "supergiant" field is one that contains at least 500 million barrels. On a worldwide basis, however, the term "giant" usually refers to fields with recoverable resources of 500 million barrels or more.

; Petroconsultants, Reserves and Production Database, Geneva.

8 Tiratsoo, E.,N., Oilfields of the World, $3^{\text {rd }}$ edition (Houston, Texas: Gulf Publishing Company, 1984), p. 23

9 US Department of Interior, Minerals Management Service and U.S. Geological Survey, Estimates of Undiscovered Recoverable Conventional Oil and Gas Resources in the United States - A Part of the Nation's Energy Endowment (Washington, DC. 1989) 
Figure 3.5 Estimated Reserves of Crude Oil by Nation, as of January 1, 1997

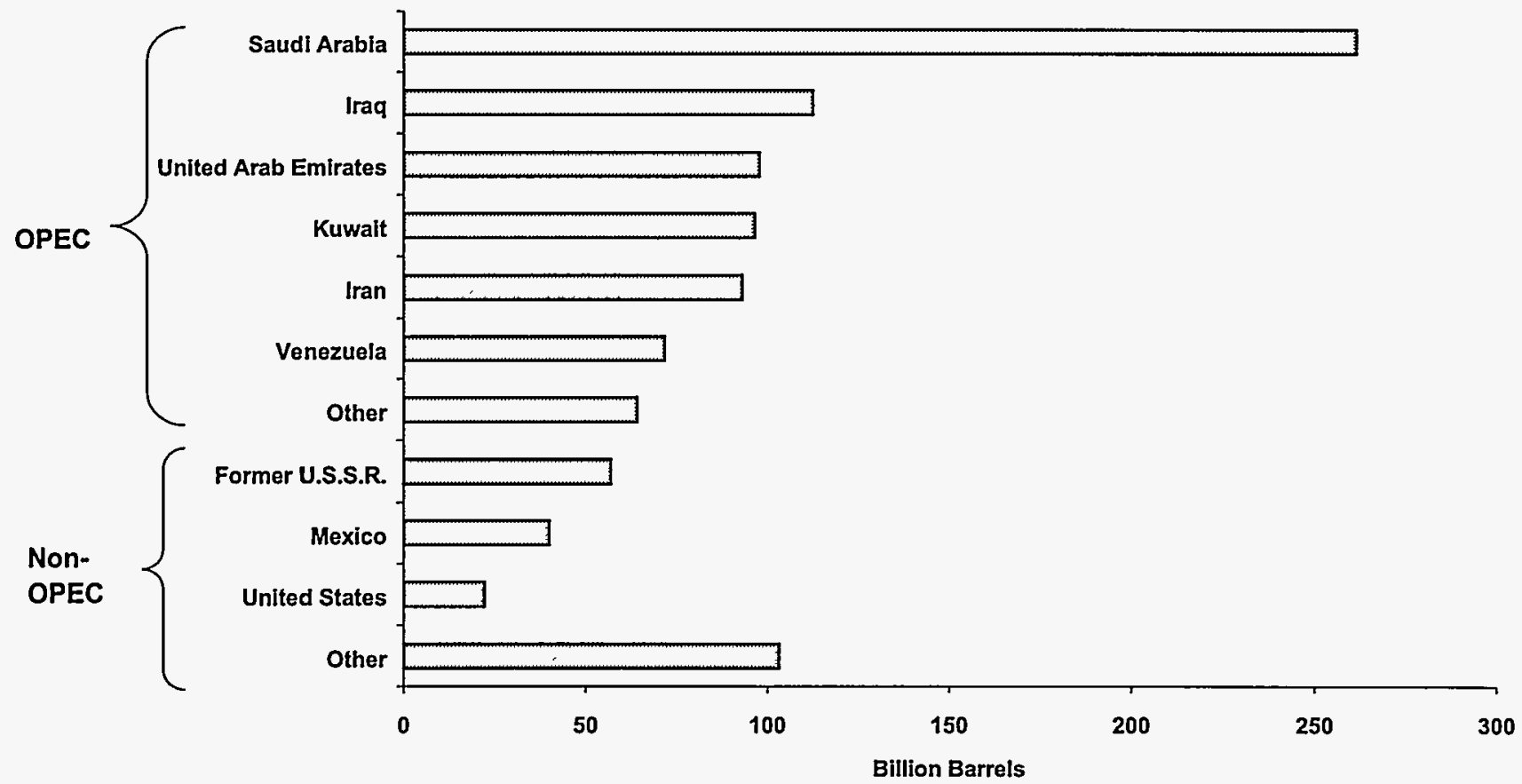

Source: Encrgy Information Administration, U.S. Crude Oil, Natural Gas, and Natural Gas Liquids Reserves 1997 Annual Report, DOE/EIA-0216(97).

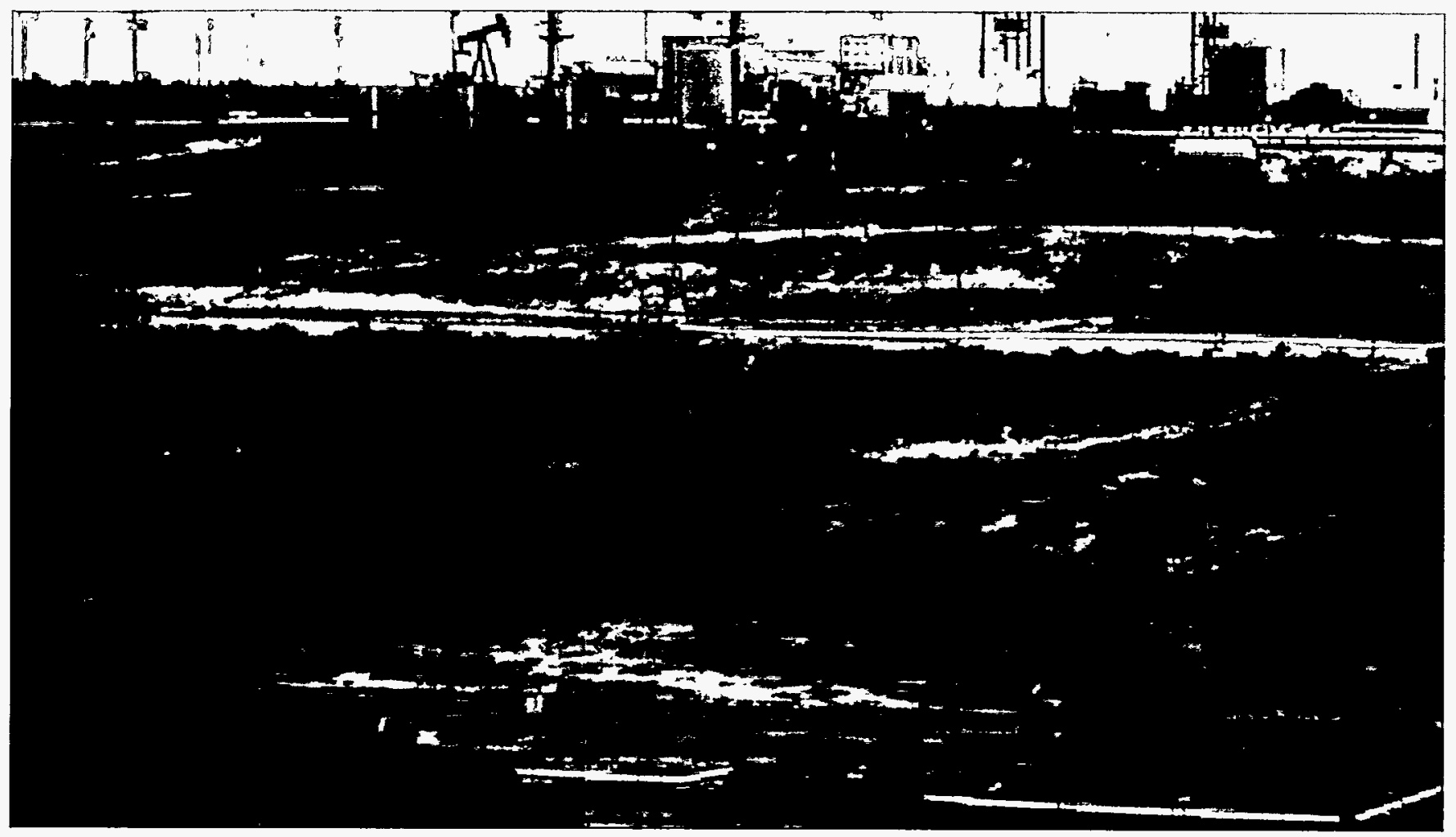

Petroleum is produced from reservoirs such as this one located at Lost Hills, California.

For more information on petroleum resources and reserves, look for the current issue of U.S. Crude Oil, Natural Gas, and Natural Gas Liquids Reserves annual report, and for the most recent data on U.S. crude oil production, see the Petroleum Supply Annual, Volume 1, both on the "Petroleum" page of EIA's website at http://www.eia.doe.gov/. World crude oil production and reserves can be found in the International Energy Annual on the "International" page of our website. 


\section{Exploration and Production}

The process of removing crude oil from beneath the earth's surface begins with exploration to find areas where petroleum deposits are most likely to exist. Drilling and extraction, comprise the production phase of oil recovery.

Commercial production of petroleum in the United States began in 1859 when "Colonel" Edwin Drake drew oil from a well in Titusville, Pennsylvania, the first modern well drilled exclusively for that purpose. Production increased steadily throughout the rest of the century, remaining centered around Pennsylvania, Ohio, and West Virginia. Then in 1901, the Spindletop well in Texas met with success, gushing oil at a rate never experienced before, and the."rush" was on. From 1901 to 1910, the rate of oil production in the United States more than tripled. By 1929, the United States, led by Texas, California, and Oklahoma, was producing over 1 billion barrels of crude oil a year. In 1948, production reached 2 billion barrels and increased almost every year thereafter until it reached its peak of 3.5 billion barrels in $1970{ }^{1}$

Today, U.S. production is influenced by several factors including reserve availability, legal accessibility of prospective drilling sites, effects of regulations covering environmental and occupational health, drilling and recov- ery technology, and crụde oil prices. Declining reserves and the declining average productivity of oil wells (number of barrels produced per day) are lowering the amount of production. As more oil is removed from reservoirs, less remains for later production; what does remain is more difficult and expensive to recover (unless new technology lowers the cost beyond the rise in difficulty). Many U.S. reservoirs have already been depleted of their easily recoverable reserves. Improving technologies for enhanced oil recovery could enable more production from these reservoirs in the future, but at the present time these methods are still very expensive, making their use unprofitable in many cases.

U.S. production levels are also greatly influenced by crude oil prices. When the price of oil is low, it becomes less profitable to explore for and produce oil, and production usually declines. The annual average number of rigs drilling for oil has dropped from 532 in 1990 to 264 in $1998 .^{2}$ Existing wells which need costly maintenance are often shut in temporarily during periods of low prices. A substantial number of those shut-in wells will be permanently plugged as prices continue to fall. In 1986, a major drop in the price of crude oil caused production to decline by about 3 percent to 8.7 million barrels per day. Although prices fluctuated between 1987 and

\section{Figure 4.1 World Crude Production in 1997 (Million Barrels per Day)}

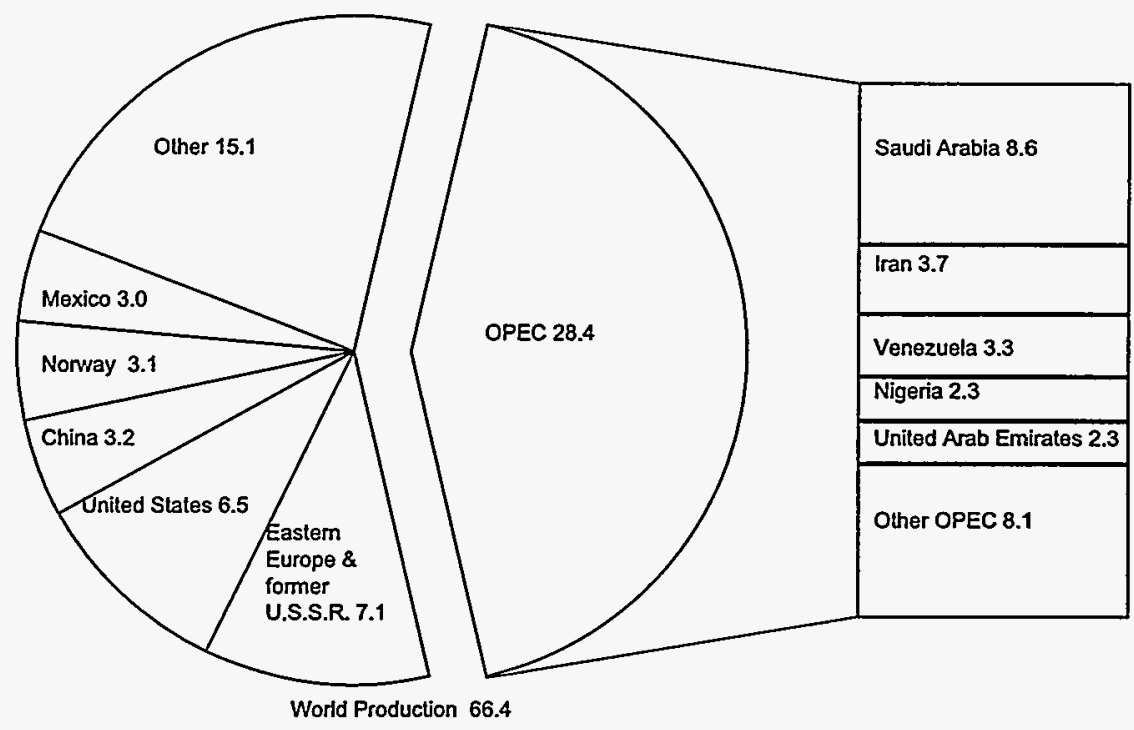

Notc: Totals may not equal sum of components due to independent rounding.

Source: United States: Energy Information Administration, Petroleum Supply Annual 1997, DOE/EIA-0340(97)/1. Rest of world: Energy Information Administration, International Energy Annual 1997, DOE/EIA-0219(97).

I American Petroleum Institute, Basic Petroleum Data Book, Vol. 11, No.1 (Washington, DC, January 1991), Section 4.

2 Baker-Hughes, Inc. Houston, Texas, weekly phone recording. 
1990 , they remained well below the levels of the early 1980's and production continued to decline, falling to 7.4 million barrels per day by 1990 . Higher prices in the last half of 1990 boosted domestic crude oil production slightly in 1991, but were unable to reverse the 6-year downtrend that saw domestic production decline by 1997 to its lowest level since 1954 . This downward trend is expected to continue at a rate influenced by the world oil price.

Saudi Arabia, the United States, and Russia are the largest petroleum producing nations in the world. The United States accounted for about 10 percent of the total world production of crude oil in 1997 (Figure 4.1). Saudi Arabia produced about 13 percent of the world total and is currently the world's largest producing nation, while Russia accounted for about 9 percent of the world total in 1997. Crude oil production in Russia, falling since 1988 with the dissolution of the Soviet Union, showed a small increase in 1997.

Offshore areas contributed nearly 25 percent of U.S. crude oil production in 1997 at a rate of 1.6 million barrels per day (Figure 4.2), the highest level since 1973. The increased share of offshore production in 1997 reflects the reduced production in large onshore Alaska fields. The giant oil fields in Alaska were discovered in the late 1960 's, but significant production did not begin until the Trans-Alaska Pipeline System was completed in 1977 (Figure 4.3). Alaskan production began to decline in 1989 , largely because of the natural decline of the Prudhoe Bay field. In 1997, Texas was the leading U.S. producing State, accounting for 23 percent of U.S. crude oil production. Alaska was the second largest with 20 percent, followed by California with 12 percent, Louisiana with 6 percent, Oklahoma with 4 percent and Wyoming with 3 percent. These six States, together with Federal offshore areas, accounted for 87 percent of the crude oil produced in the United States during 1997.

\section{Exploration}

Before the turn of the century, prospectors relied on their senses, some simple instruments like divining rods, and mostly luck to help them find oil. They often drilled in areas where oil was seen seeping from the earth, or where surface features resembled those around earlier oil discoveries. Around 1900, oil seekers began to employ scientific techniques. Geologists, and later geophysicists, began to study the Earth's structure, looking for areas of sedimentary rock and for irregularities in rock formations which could cut off migrating oil and cause it to accumulate in reservoirs. Today, explorers measure such things as magnetic fields and differences in the pull of gravity to help identify promising formations, but the most widely used technique is the seismic survey.

During a seismic survey, the ground is vibrated to create sound waves. Geophones (ultrasensitive microphones) set out along the ground monitor the sound waves and measure
Figure 4.2 Onshore and Offshore U.S. Crude Oil Production, 1970-1997

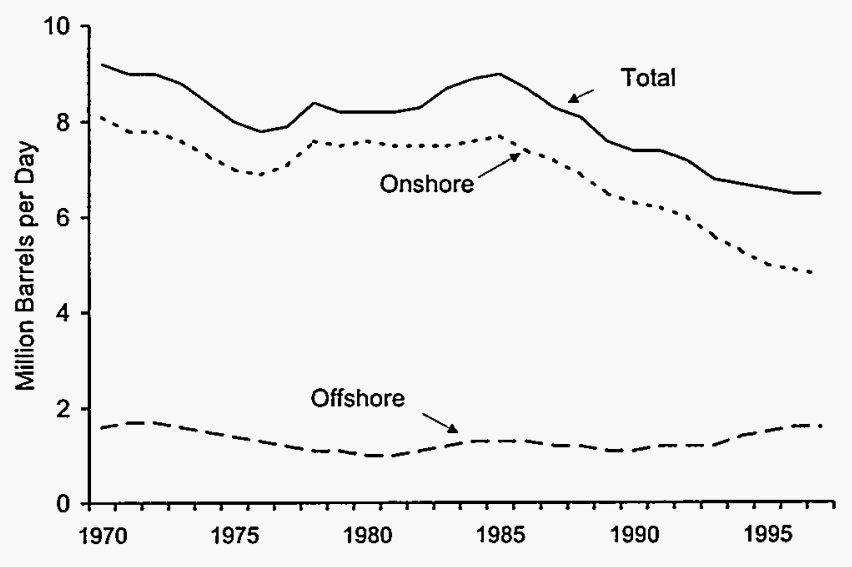

Source: 1970-1996: Energy Information Administration, Annual Energy Review 1997, DOE/EIA-0384, 1997: Encrgy Information Administration, Petroleum Supply Annual 1997, DOE/EIA-0340(97).

\section{Figure 4.3 Geographic Origins of U.S. Crude} Production, 1970-1997

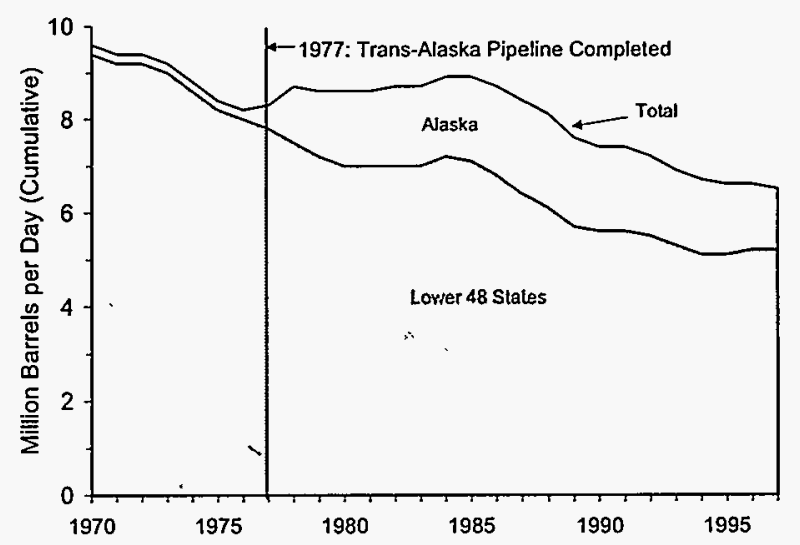

Source: 1970-1996: Energy Information Administration, Annual Energy Review 1997 DOE/EIA-0384(97), 1997: Energy Information Administration, Petroleum Supply Annual 1997. DOE/EIA-0340(97).

the time it takes for them to reflect from subsurface rock formations. Maps of the underground structure can be produced from these measurements.

Dynamite explosions used to be the primary means of producing vibrations, but today specially designed trucks which vibrate the ground with heavy weights are often used instead. The trucks are safer and less harmful to the environment. Computers filter out excess noise and otherwise aid the interpretation of seismic data. They also facilitate the production of maps and cross-sections: using new techniques, two- or three-dimensional images of the underground structure can be created.

Seismic surveys are also conducted offshore where hydrophones towed behind a seismic ship perform the same function as geophones. The sound waves are generally created by air or gas guns which are also towed by the ship. Measuring reflection times is more difficult offshore because 
vibrations pass through the water before reaching the earth. Computer programs are used to distinguish significant reflections from unwanted noise and to determine structure locations. While seismic surveys for many years produced two-dimensional charts along the line of the survey, three-dimensional (3D) surveys are now commonplace in both exploration and development of oil and gas fields. The image from a 3D survey can help with placement of future oil wells and is especially useful if a horizontal well is planned. Two or more 3D seismic surveys conducted over the same area are known as four-dimensional (4D) seismic, with time as the fourth dimension. A 4D survey can show the movement of distinct fluids in a reservoir, allowing modification of drilling and production operations to capture more oil.

Seismic exploration activity peaked in 1981 in response to high crude oil prices which gave companies incentives to search for more oil reserves. By contrast, when crude oil prices fell in 1986, the number of seismic crews working fell almost 50 percent from the level of the previous year.

Other methods of exploring from remote positions, including the recording of magnetic and gravity measurements from airplanes and the use of satellite images to locate areas

\section{Figure 4.4 A Rotary Drilling System}

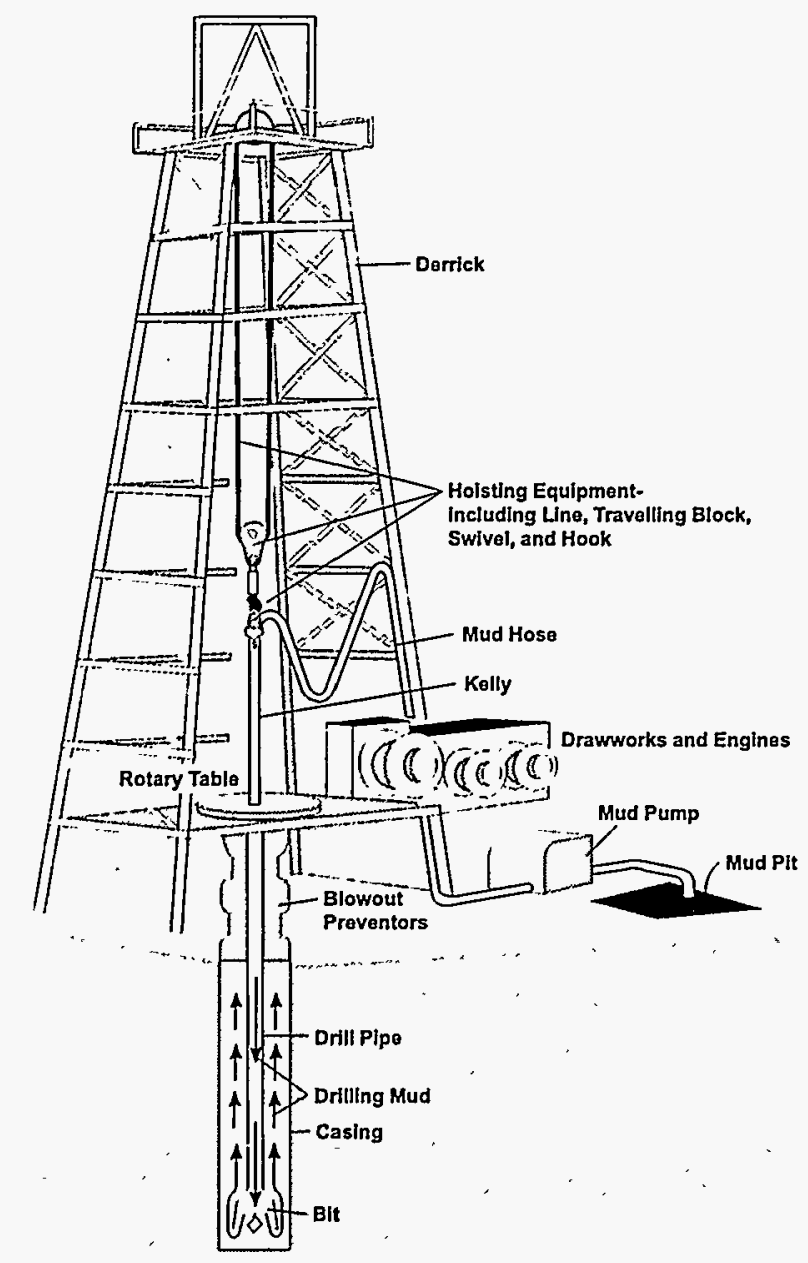

Source: Encrgy Information Administration, Office of Oil and Gas. are continually being developed. Although scientific data can greatly improve the chances of finding oil in a particular area, there is no way to be sure oil exists, or that enough oil will be found to make its recovery profitable, without actually drilling a well.

\section{Drilling}

Before there was a great demand for petroleum, people dug and drilled wells into the earth to reach sources of water and salt. Oil well drillers adopted techniques from these earlier drillers, and added some innovations of their own. One early drilling rig, consisting of a springing pole attached to a rope with a heavy bit at the end, was operated by a person's foot, and an early rotating drill was operated by mule power. Colonel Drake's 1859 well was drilled using a cable-tool rig, a device which pounds a chisel-like bit into the ground. The rig was powered by a steam engine. The Spindletop well in Texas, in addition to being America's first gusher, was notable as one of the earliest successful uses of a modern rotary drilling system (Figure 4.4). A rotary rig uses a rotating bit which drills a hole into the ground. Today, some wells are still drilled with cable-tool rigs, but use of the cable-tool rig has been far surpassed by the rotary rig. Coiled tubing drilling using a continuous small pipe ( 2 to 4 inches) with a downhole hydraulically-driven mud turbine motor to power the rotating drill bit has been used in an increasing number of wells since 1990.

A rotary-rig bit cuts and crushes rock as it descends. The bit is attached to the bottom of a long string of steel pipe. At the top of the string is the kelly, a square or hexagonal section of pipe that is inserted through a steel disk known as the rotary table. The rotary table has a square or hexagonal hole in the center to receive the kelly and is geared to a motor at its perimeter. The table turns, rotating the whole string of kelly, drill pipe, and bit.

As a well gets deeper, more pipe is added to the drill string below the kelly. Support for the heavy drill string is provided by a tall steel structure known as a derrick. The derrick contains heavy equipment which can lift the entire drill string from the well and then return it, an operation called tripping that must be done to change the bit (drill bits wear out in use, also certain rock types are drilled more efficiently with specialized bits), make repairs to the downhole drillstring, and test the well. During a complete trip, all of the drill pipe is removed from the hole, unscrewed into 90 foot sections, and stacked, and then the whole process is done again in reverse.

Drilling mud, usually a mixture of minerals and water or oil, is critical to drilling. Mud is pumped down the well through the center of the drill string and drill bit and then circulated back to the top, pushing the pieces of rock which have been cut by the bit up and out of the hole. The mud also keeps the bit cool, coats the sides of the well to keep soft rock forma- 
tions from caving in, and controls pressure from fluids in the formation to prevent blowouts (sudden explosive releases of gas or oil). Properties such as the weight and thickness of the mud are specifically designed for each well. Some geologic formations allow the use of air as a drilling "mud", especially where clay minerals in the rocks show a tendency to swell when wetted with water, thereby plugging a reservoir's pore spaces.

Most wells are lined with steel pipe, known as well casing, which is cemented into place. It prevents collapse of the sidewalls of the well and prevents the unwanted movement of fluids between rock layers. During drilling operations, a set of strong valves known as blowout preventers is affixed to the top of the surface casing beneath the rotary table. If a high pressure zone of oil or gas is encountered while drilling, these valves can be closed to prevent a blowout. When the well is producing, the top of the casing serves as a place to connect the surface equipment. Production tubing is inserted into most wells as part of the completion process. It can allow simultaneous production from more than one reservoir at a time.

In onshore operations, a rig usually drills a single vertical well. Offshore rigs most often drill several wells from one location using directional drilling, where the angle of a well is diverted from vertical. Directional drilling is also used onshore to reach under obstacles such as riverbeds and lakes. In recent years, there has been an increase in horizontal drilling activity. Horizontal drilling can reach difficult areas of thin reservoirs, and can also be used to increase the area of a reservoir that can be contacted by one well, substantially increasing the rate of production. Horizontal wells are usually drilled off of vertical wells as they approach the oil-rich zone. Existing wells have had horizontal sections or laterals added in the producing zone using coiled tubing drilling units. In 1997, the average cost for drilling oil wells horizontally was 24 percent higher than the average cost for oil wells not drilled horizontally. ${ }^{3}$

Offshore drilling methods are similar to those used onshore, but the equipment must be adapted to meet the harsh marine conditions. A special structure is needed to support the derrick and other drilling equipment. This structure may rest on the sea floor or float in or on the water. The type of structure chosen usually depends on the water depth, weather, and sea conditions in the area where drilling will occur.

The major types of offshore drilling rigs are: barges, fixed platforms, jack-ups, semi-submersibles, and drill ships. Barges are used in inland waters while the others are usually used off the coast. Fixed steel platforms rest on the sea floor, usually in shallow water, and they are seldom moved once they have been put in place. Jack-ups have legs which can be
Figure 4.5 Average Cost of Oil Well Drilling, 1970-1997

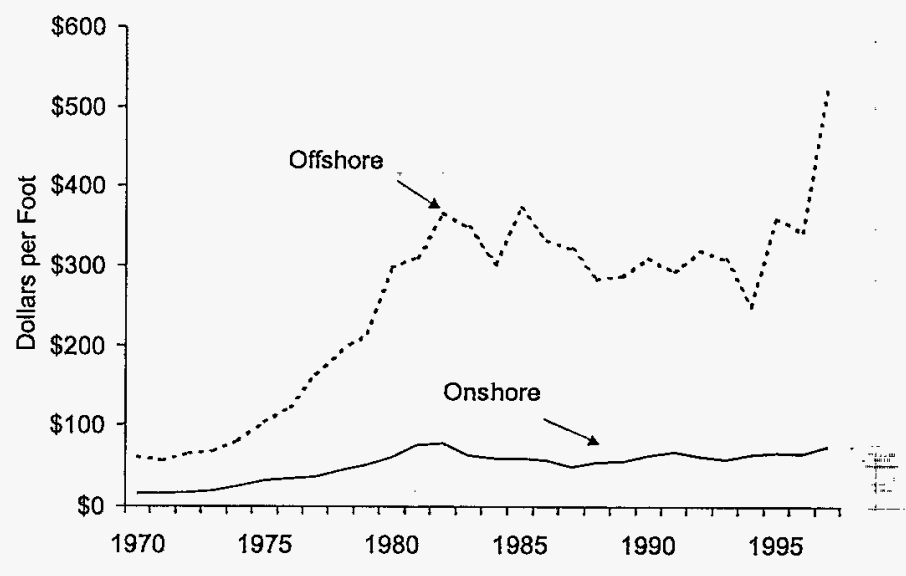

Source: American Petroleum Institute, Basic Petroleum Data Book, January 1999, volume XIX, No. 1, Tables 4 and 5 .

raised up and down in a manner similar to the action of an automobile jack. With the legs raised they can be moved to a location, then the legs can be jacked down to the sea floor. The base of a semi-submersible rig actually floats below the surface of the water. Its position-holding anchors are supplemented by the computer-controlled motors of the vessel. Semi-submersibles are very stable in bad weather conditions and yet can be moved from place to place. Drill ships, which have been adapted for drilling by cutting out a vertical opening in the middle of the ship, have been used in the deepest waters. These ships use anchors or motors to hold them steady over the well.

Because of the difficulty of transporting drilling crews to offshore locations, offshore rigs provide living quarters for the workers, with facilities for sleeping, eating, entertainment, and other activities not usually provided at onshore drill sites. Helicopters are now the primary means of transportation between land and rig. Therefore, one prominent feature of the offshore rig is a helipad. In case of hurricanes in the Gulf of Mexico, crews must secure the production platforms and leave well ahead of the possible arrival of a hurricane.

Offshore wells are much more expensive to drill than onshore wells (Figure 4.5). In 1997, the average onshore oil well cost $\$ 74.23$ per foot drilled, while the average offshore well cost $\$ 526.37$ per foot. ${ }^{4}$ Drilling costs are also influenced by well depth and the characteristics of the formations being drilled.

The number of wells drilled usually responds to changes in the price of crude oil. When crude oil prices were increasing during the late 1970 's, companies invested in more drilling

3 Amcrican Petrolcum Institute, Joint Association Survey on 1997 Drilling Costs, (Washington, DC, November 1998), p. 4.

4 Amcrican Petroleum Institute, Joint Association Survey on 1997 Drilling Costs, (Washington, DC, November 1998) p.1 and Table 2.9. 
activity. For the most part, U.S. drilling activity has decreased since the 1981 price peak. In 1986, the number of oil wells completed fell almost 50 percent from the previous year. Rising crude oil prices following Iraq's invasion of Kuwait in 1990 helped increase drilling activity for the first time since 1984. However, the total number of oil well completions fell from 35,118 in 1985 to 6,300 in $1998 .^{5}$

Exploratory wells are those wells drilled to search in areas not already proven to have oil reserves, to find the limits of a newly-discovered reservoir, or to find new reservoirs in fields where reserves are known to exist. In 1997, about 5 percent of all oil wells drilled were exploratory wells and the remainder were development wells. ${ }^{6}$ Development wells are those drilled in areas which have already been proven to have a productive reservoir. Of all the oil and gas wells drilled in 1997, about 22 percent of the exploratory wells and about 81 percent of the development wells were successful in finding hydrocarbons.

A long-term decline in average well productivity is now underway in the United States (Figure 4.6). On average, oil wells produced just under 11 barrels per day, as in 1997. The United States has a very large number of stripper wells, wells which produce less than 10 barrels per day as compared with many other oil producing countries. Because stripper wells are less profitable, they are more seriously affected by low crude oil prices. Many stripper wells have ceased production and were shut-in during either the price drop in 1986 or in 1998. Some of these wells may be reopened for production if crude oil prices increase and remain high. State oil and gas production regulations require that oil wells shut-in for more than a set period of months must be plugged and abandoned; i.e., the metal production casing is removed and the well filled with cement through all producing and water-bearing zones.

\section{Development and Recovery}

When a commercially producible deposit of oil is found by drilling, development wells are planned, drilled, and completed so that the oil can be brought up to the surface efficiently. In most producing wells, casing is cemented into place beyond the zone to be produced and the casing is then perforated so that oil can flow into the well. Occasionally, perforation is done by bullets discharged from a specially designed firearm, but more often holes are made in the casing by shaped explosive charges which are lowered into the well. Sinaller steel pipe, known as production tubing, is run inside the casing and a packer is put in place between the tubing and casing to isolate the producing zone from the rest of the casing. Crude oil is brought up through the tubing. A second set of tubing in the casing can be used to produce oil from a sec-
Figure 4.6 Average Productivity of U.S. Oil Wells, 1965-1997

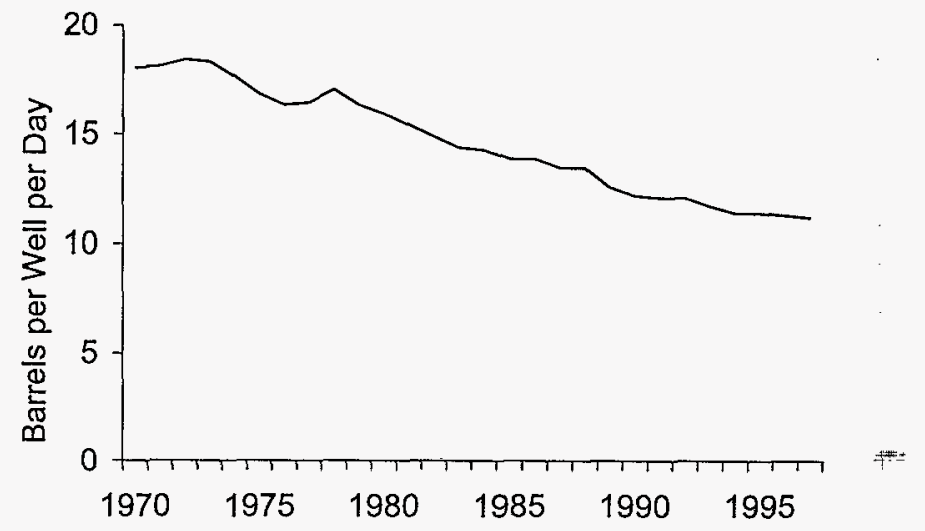

Source: 1970-1997, Energy Information Administration, Annual Energy Review 1997, DOE/EIA-0384(97).

ond reservoir within the field. A "Christmas tree" is installed at the top of the casing and tubing to control the flowing oil. The Christmas tree is a set of valves and fittings designed especially for the production of a particular well.

\section{Well Testing}

In most cases, the drill string must be removed from the well in order to conduct well tests, but new automatic systems which can provide certain measurements while drilling continues have been developed. Wells, both exploratory and development, are usually tested during and after drilling to determine if an oil producing formation has been reached. Well logging instruments may be lowered into a well to measure many characteristics, such as temperature, electrical resistance, and radioactivity. The logging data collected from these instruments are used to determine the characteristics of the rocks and fluids found in a well. Today, many wells are drilled with equipment which measures these rock characteristics while the well is being drilled. Core samples provide another means of determining rock and fluid characteristics, as well as allowing visual examination of the well contents. A core sample is a cylindrical section of the rock formation taken from the center or side wall of a well. The well may also be produced to a flare stack to judge the possible rate of production.

Petroleum in an underground reservoir is usually under great pressure. Because an open well has lower pressure, oil will flow toward it. The rate at which oil will flow through the reservoir and into a well, where it can be raised to the surface, depends on the permeability of the rock formation and the thickness, or viscosity, of the oil.

5 Energy Information Administration, Monthly Energy Review, March 1999, DOE./EIA-0035(99/03), Table 5.2.

6 American Petroleum Institute, Joint Association Survey on 1997 Drilling Costs, (Washington, DC, November 1998) Tables 2.6 and 2.7. 
A well is considered to have natural lift if it has sufficient pressure and the oil has low enough viscosity to flow up through the tubing to the surface on its own. Gas or water, which reside in the reservoir with the oil, can provide the pressure needed to create natural lift. Gas may be dissolved in the oil or form a "gas cap" (also known as associated gas) on top of the oil, or both. As the pressure is reduced in a gas cap reservoir, dissolved gas is released from the oil and the gas cap expands, pushing the oil through the reservoir and into the well. Any water that is present in a reservoir will lie underneath the oil, because oil is lighter than water, and creates a water drive, pushing oil toward the lower pressure in the well. If natural lift is not present, artificial lift methods must be used to bring the oil up. Many U.S. oil wells, under production for a long time, have lost much of their natural pressure. By 1997, about 96 percent of the producing oil wells in the United States used artificial lift methods. ${ }^{7}$
Artificial lift is usually provided by pumps or by gas lift. The most common type of pump is a walking beam pump (sometimes known as a horsehead pump), which provides the familiar up and down stroking action often seen at well sites. Sometimes electrically or hydraulically powered submersible pumps are placed at the bottom of the well. Gas lift is created by injecting gas down the well between the casing and tubing. Valves are opened up in the tubing allowing the gas to mix with the oil, making it less dense and increasing its ability to flow.

The rate at which oil flows through the reservoir can be increased by stimulation techniques which enlarge the spaces in the formation. Acidizing and hydraulic fracturing are the most frequently used methods. In the former, an acid, usually hydrochloric acid, is pumped down the well into the pores where it eats away some of the rock and opens larger spaces. In hydraulic fracturing, a fluid is pumped down, under pres-

Figure 4.7 Secondary Recovery Using Water Injection to Supplement Drive

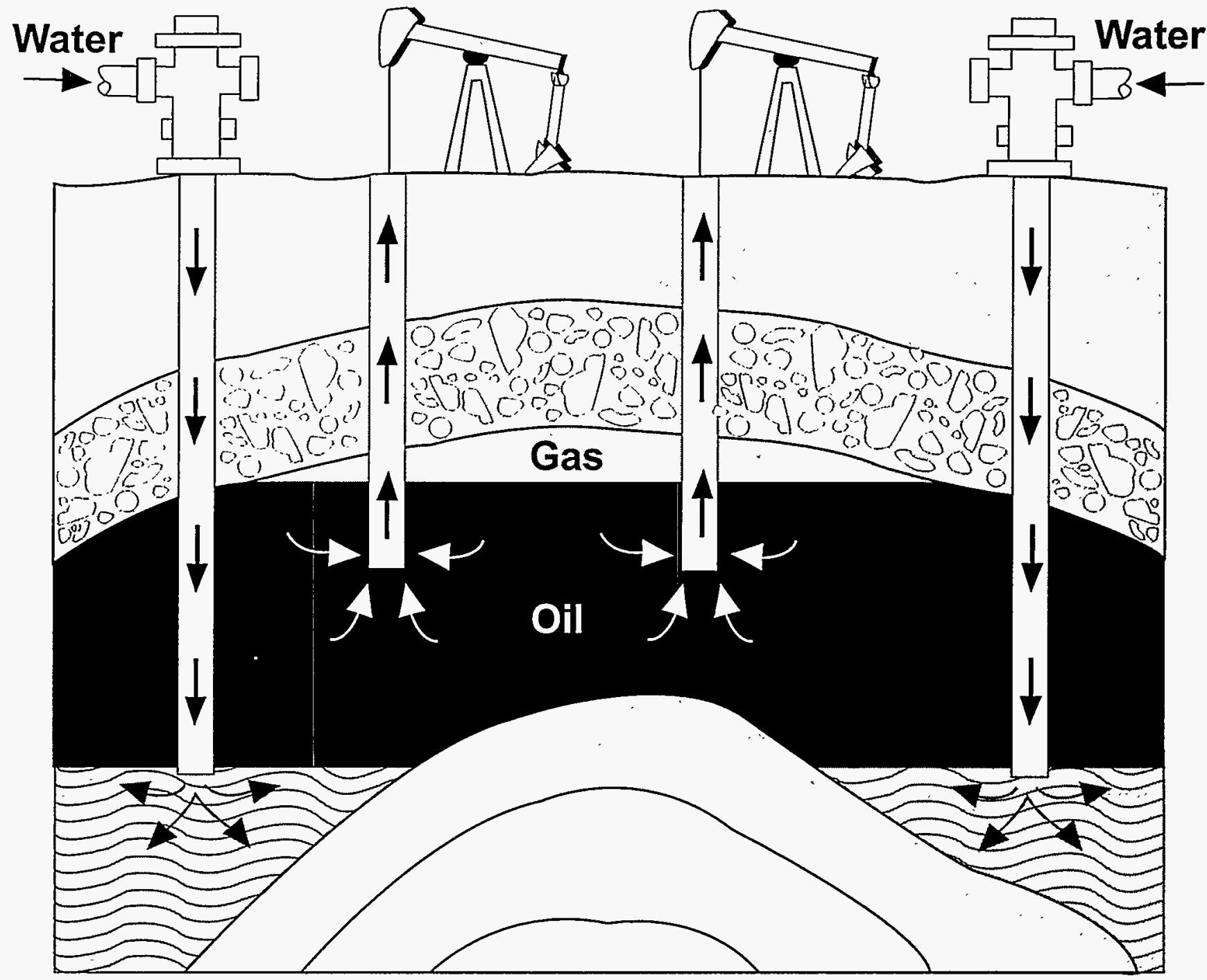

Source: Energy Information Administration, Office of Oil and Gas.

7 "Producing Oil Wells: Paying the Pricc," World Oil, Vol. 212, No. 2 (Houston, Texas: Gulf Publishing Company, February 1991 ) p. 64. 
Figure 4.8 Enhanced Recovery Using Continuous Steam Injection

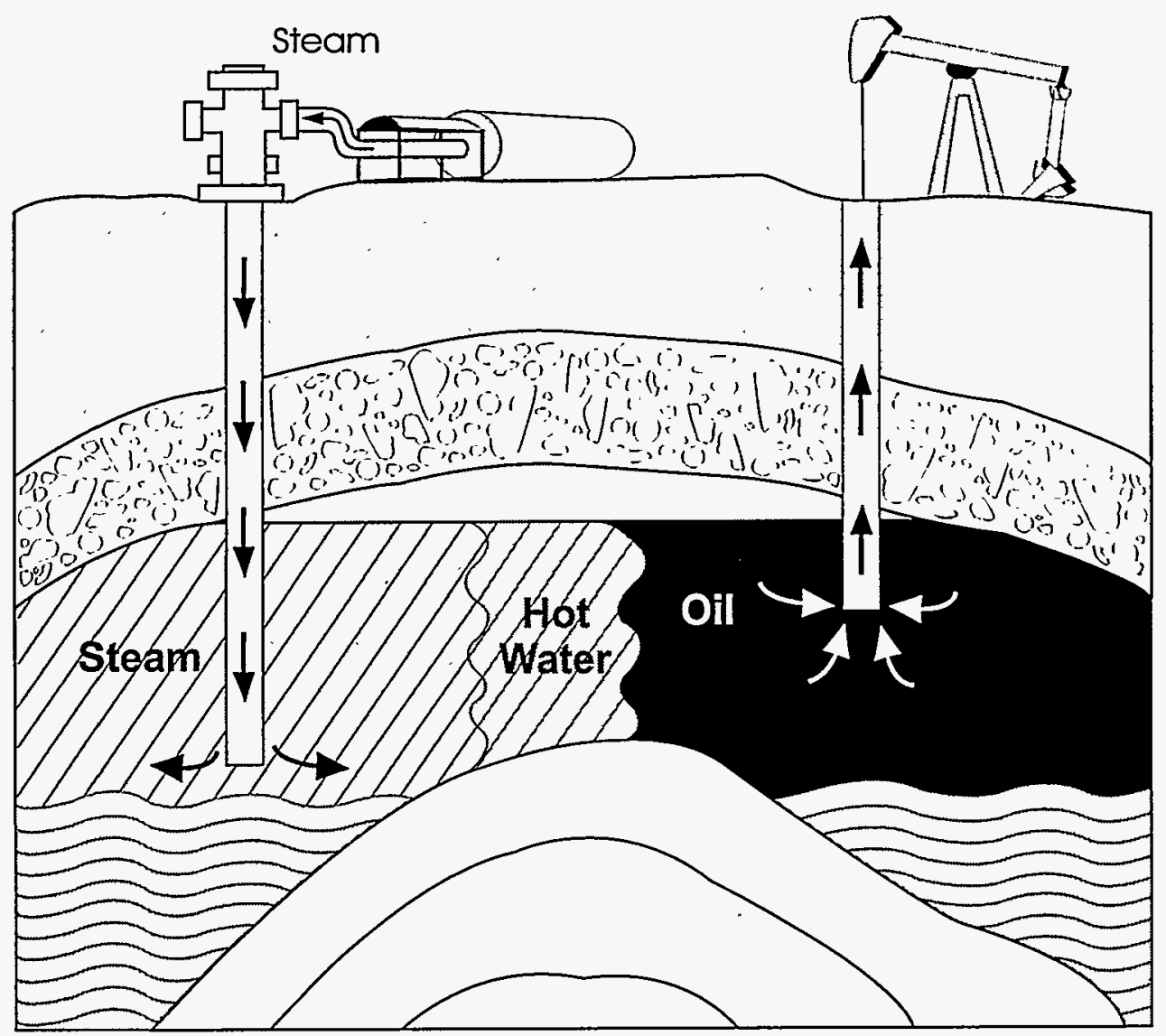

Note: In the cyclic, or huff and puff, method, steam is injected and oil is recovered through the same well. The well is shut in (not producing oil) for a few days between steam injection and recovery.

Source: Energy Information Administration, Office of Oil and Gas.

sure, causing the rock to crack. The fluid contains a propping agent, usually sand, which settles into the cracks and holds them open, but still allows oil to flow through.

The recovery techniques described above are usually referred to as primary oil recovery methods. When oil no longer flows sufficiently using the primary methods, secondary and tertiary, or enhanced, recovery methods may be tried to bring the remaining oil up. The use of these methods depends on estimates of the amount of oil remaining and on the cost of the method.

\section{Secondary and Enhanced Recovery}

The most common secondary method is waterflooding. Water is injected through wells at the surface into the reservoir. The water injection wells are placed so that the water will push the oil ahead of it, out of the pore spaces, toward the producing well (Figure 4.7).

There are three principal methods of enhanced oil recovery: chemical flooding, miscible flooding, and thermal recovery. Chemical flooding is the same as waterflooding except that chemicals are mixed with the water to aid oil flow. Miscible flooding uses carbon dioxide or other gases as a flooding agent. Thermal recovery is accomplished by in situ combustion or steam injection. In the former, a fire is started underground, burning a portion of the oil. In the latter, steam is injected into the well, either in a continuous flow or in cycles (huff and puff) (Figure 4.8). Both methods heat the fluid in the reservoir, thinning the oil and increasing its rate of flow toward the well. Thermal methods also increase pressure, which aids in pushing oil through the reservoir. Steam injection is the most frequently used enhanced recovery technique.

\section{Preparation}

After oil is brought to the surface, small pipelines called flow lines carry it to a part of the production site known as the tank battery. In addition to storage tanks, the tank battery contains equipment for preparing the oil before further distribution. The fluid coming out of nearly all wells is actually a mixture of oil, gas, salt water, and sediment. First, any gas present is separated from the oil and water, then the gas may then be sent to a processing plant or re-injected to help maintain reservoir pressure and thereby production. Separation of the remaining mixture may be accomplished in special tanks where the settling process separates water and oil, or it may be assisted by special equipment such as a heater treater. The 
remaining fluid may be put through several different treatments, depending on its contents. For example, sediment may have to be removed, or a chemical treatment may be applied to remove unwanted gases like hydrogen sulfide and carbon dioxide. Crude oil from offshore wells is usually processed through a separator on the platform then shipped via pipeline to storage and treatment facilities onshore.

The physical properties of oil differ for each reservoir. The price for which oil can be sold depends not only on volume but also on the oil's characteristics, particularly its specific gravity and its sulfur content. Testing of the oil to determine these properties is conducted at the well site by taking samples of oil from the storage tanks. Specific gravity is a measure of the density of the oil. Light, low density oil has a low specific gravity. However, the specific gravity of oil is usually measured on the American Petroleum Institute (API) scale which expresses gravity in terms of degrees API. A low specific gravity translates to high API gravity and vice versa.
Thus the lightest, least dense oils are those with the highest API gravities.

Oil volume can be measured by several techniques but is usually accomplished by gauging the level of oil in a tank before and after shipment or by allowing it to flow through a meter. Temperature is also measured because it affects the volume of the oil. Some sites today are equipped with Lease Automatic Custody Transfer facilities (LACT's) which do most of the measuring, sampling, and testing without human intervention. Oil that has been completely prepared is stored in tanks at the well site until it is transported to the refinery.

Crude oil prices will continue to influence exploration and production activity in the future. In the long run, U.S. domestic production will undoubtedly decline. The rate of decline will be influenced not only by oil prices, but also by the dynamics of the resource base over time, as well as offsetting technological advancements in exploration, development, and recovery methods.

For more information on petroleum resources and reserves, look for the current issue of U.S. Crude Oil, Natural Gas, and Natural Gas Liquids Reserves annual report, and for the most recent data on U.S. crude oil production, see the Petroleum Supply Annual, Volume 1, both on the "Petroleum" page of EIA's website at http://www.eia.doe.gov/. World crude oil production and reserves can be found in the International Energy Annual on the "International" page of our website. 


\section{Petroleum Refining}

The petroleum refining industry provides the link between crude oil and the finished product. Because the uses for crude oil as it comes from the ground are limited, the petroleum refinery is the key to unlocking the full potential of this valuable resource. There are many refinery processes employed to transform crude oil into the array of products used in transportation, electric power generation, home heating, and countless other applications.

The United States leads the world in refinery output, producing 23 percent of the worldwide output of petroleum products. "As of January 1,1997 , an estimated 20 percent of the crude oil refining capacity in the world was located in the United States.

Petroleum refining is one of the leading manufacturing industries in the United States. The value of shipments by the petroleum refining industry accounts for about 4 percent of the value of shipments by the entire manufacturing sector of the U.S. economy. ${ }^{2}$ In 1996, the value of shipments by the petroleum refining industry was an estimated $\$ 158$ billion. $^{3}$
Nearly one-half of all U.S. refinery output is motor gasoline. The industry responds to changes in demand by adjusting refinery processes to vary the yield of gasoline and other products. For example, in 1921, the yield of gasoline per barrel of crude oil was about 27 percent. In 1997, the gasoline yield at U.S. refineries was about 46 percent, reflecting the high demand for automotive fuels.

The first phase in refinery processing, atmospheric distillation, uses heat to separate the various hydrocarbon components (Figure 5.1). Beyond the atmospheric distillation unit, or "downstream" from this initial refinery process, are more complex units that increase the refinery's flexibility to process a wide range of crude oils and increase the yield of lighter (low-boiling point) petroleum products such as gasoline. The streams of material coming from the distillation unit can be used as finished products or they can become feedstocks for the downstream processes described later in this chapter and in the Appendix B. ${ }^{4}$ Downstream operations include vacuum distillation units; "cracking" units that use heat, pressure, or catalysts to increase the yields of lighter products; "reforming" units that upgrade low octane naph-

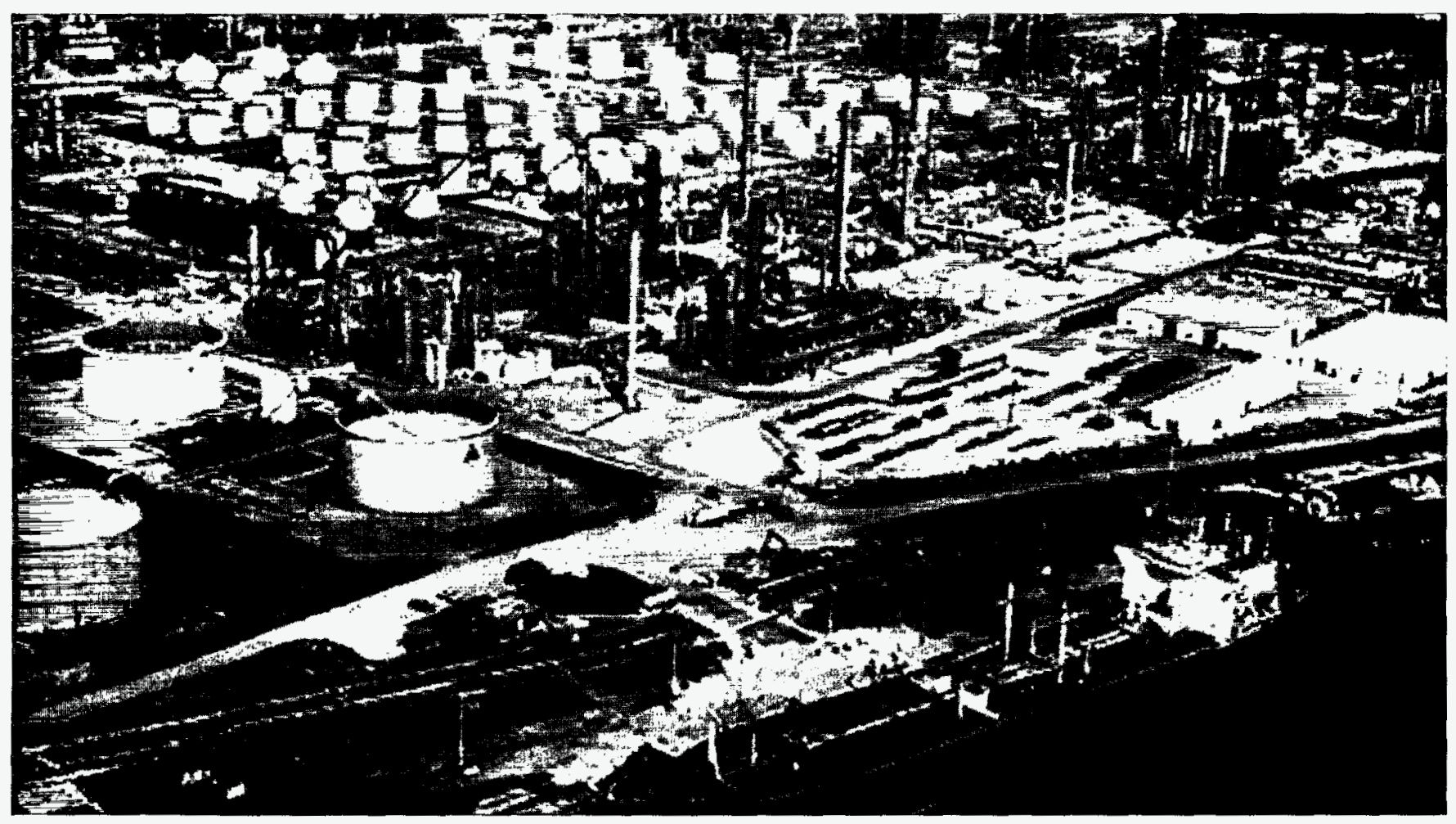

Refineries employ many different processes to convert crude oil into numerous petroleum products.

1 Energy Information Administration, International Energy Annual 1997, DOE/EIA-0219(97) Table 3.2.

2 U.S. Department of Commerce, Bureau of the Census, 1996 Annual Survey of Manufactures, Statistics for Industry Groups and Industries (M96AS1), Table 2.

3 U.S. Department of Commerce, Bureau of the Census, 1996 Annual Survey of Manufactures, Statistics for Industry Groups and Industries (M96AS1), Table 2.

4 In addition to crude oil and the products of other refinery processes, "refinery inputs" (feedstocks for refinery processing units) can include natural gas liquids (NGL's) recovered in natural gas processing plants. 


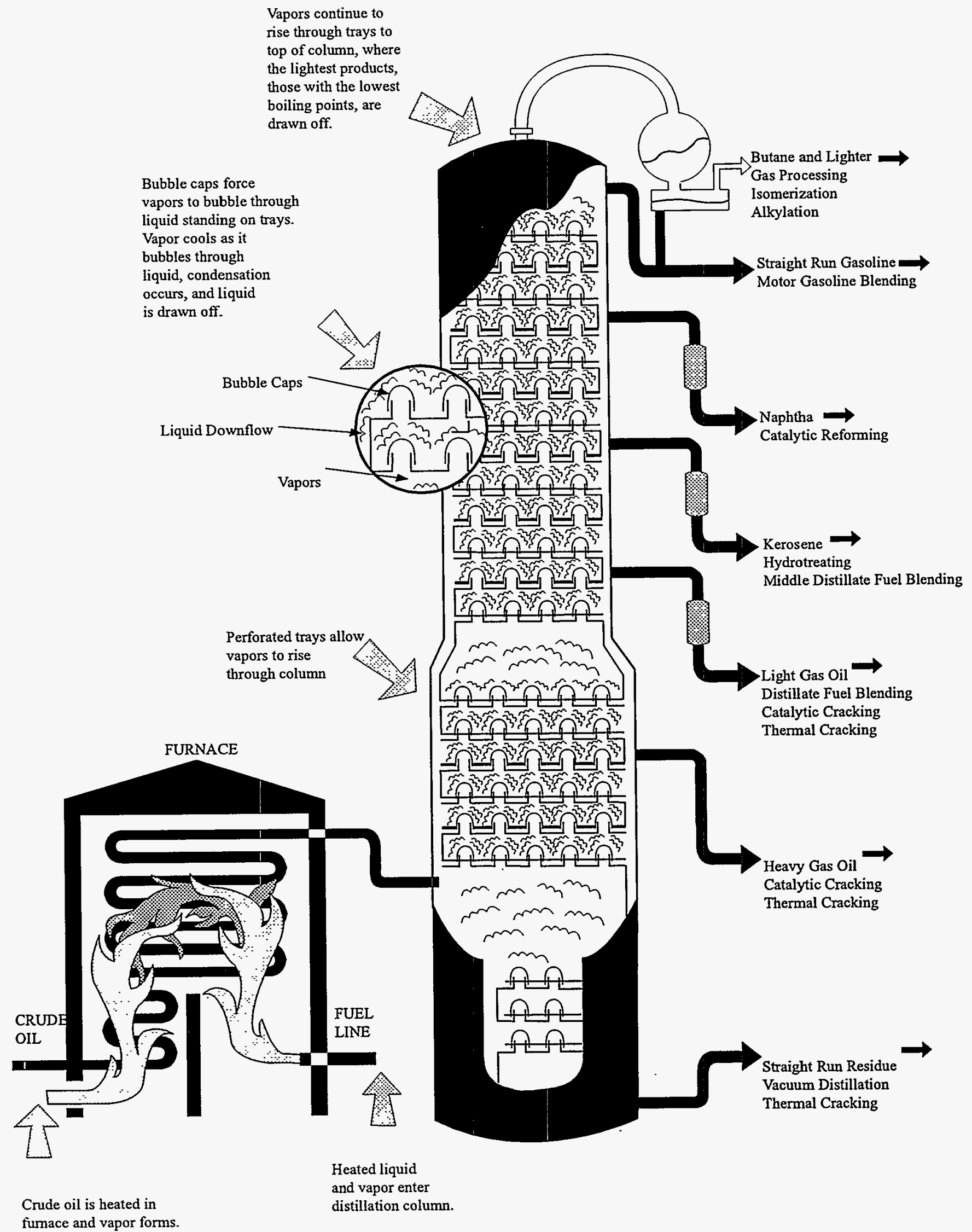

Source: Energy Information Administration, Office of Oil and Gas: 
thas to a high octane gasoline blending component called "reformate"; and process units that combine molecules to yield products with specific properties. Some refineries also have operations to pretreat feedstocks, remove impurities, and enhance various product characteristics.

Crude oil is not a homogeneous substance. Crude oil varies in color, viscosity, sulfur content, mineral content, and other characteristics, depending on the source. The quality of crude oil depends largely on its geographic origin, although the time a reservoir has been in production is also a factor. (The same reservoir will produce progressively heavier crude oil over time, as the lighter oil is drawn off and heavier oil remains.)

Not all refineries are alike. The complexity of a refinery depends upon the physical properties of the crude oil to be processed there and the characteristics of the desired product that will be produced there. Because refinery process requirements differ with the quality of crude oil inputs, a refinery's geographic proximity to the source of its crude oil inputs can influence its configuration. ${ }^{5}$

Modern refineries process various blends of many different crude oils, and different configurations of refining units are used to produce a given slate of products from available crude oils. A change in the availability of a certain type of crude oil can affect a refinery's ability to produce a particular product. For example, because the sulfur content of crude oil affects the quality of finished products such as lubricants or gasoline (e.g., corrosiveness, odor, and explosion characteristics), a refinery designed to process "sweet" (low-sulfur) oil would need treatment facilities to remove the sulfur if only "sour" (high-sulfur) crude oils were available. Gravity (measure of the density of the crude oil) can also affect the complexity of a refinery. The "light" crude oils, those that have the highest API gravity (see Glossary), contain the largest proportions of easily extracted gasoline hydrocarbons, while "heavy" oils (those with lower API gravity) require more severe processing. The product slate at a given refinery is determined by a combination of demand, inputs and process units available, and the fact that some products are the result (co-products) of producing other products.

\section{Refinery Process Development}

The product slate has always reflected changes in product demand. During the mid-1800's, coal distillation produced an oil used primarily for illumination. Both this early "coal oil" and a "kerosene" produced by a similar process were smelly, smoky products. However, demand for lamp oil was growing rapidly, and the discovery of a process for making a clean burning kerosene met a ready market. Petroleum refining focused on crude oil distillation for kerosene production until the advent of the automobile and the internal combustion engine. In the early 1920 's, gasoline became the preferred product as the growing number of automobiles rapidly increased the demand for motor fuel. The growing demand for gasoline spurred the development of new refinery processes - to increase gasoline yields and improve the quality of the finished product.

Thermal cracking, a severe form of heat processing, was the first downstream process that changed the petroleum refining industry. Thermal cracking was followed by other developments in the late 1920 's and early 1930's. Polymerization produces high octane gasoline from byproducts of thermal cracking (olefins). Vacuum distillation further processes the "residuum," or product remaining in the bottom of the crude oil distillation column that will not distill at atmospheric pressure. The product left from the vacuum distillation process can be made to flow more easily by subjecting it to a thermal cracking process known as visbreaking. This process reduces the product's viscosity (the thick, gluey quality that impedes product flow). Coking, another severe thermal process, produces fuel gas, gasoline blending stocks, distillates, and petroleum coke from products left from atmospheric or vacuum distillation.

During World War II, the petroleum industry focused its technological expertise on products essential to the war effort, especially high quality aviation fuel. One result was the development of alkylation, a process in which a catalyst is used to produce a high quality gasoline component. This process became widely used after the war to produce gasoline blending stocks. Other technological advances during the war included catalytic cracking and isomerization. Catalytic cracking is similar to thermal cracking, but utilizes a catalyst to accelerate the rate of the reaction. Isomerization is a process to produce high quality gasoline blending stocks called isomers by changing the arrangement of atoms in the hydrocarbon molecule without changing the chemical composition of the compound. The isomerization process uses heat and a catalyst to convert straight-chained hydrocarbon molecules to branched-chained hydrocarbon molecules with the same chemical composition. This process increases the octane number of the light gasoline components, normal pentane and normal hexane, that are found in light, straightrun gasoline.

Catalytic reforming, a revolutionary process for converting low grade naphthas to high octane gasoline, was a major development in the late 1940's. Hydrotreating, a process to remove contaminants that would damage the catalyst used in catalytic reforming, was developed in the mid-1950's. Hydrocracking, a process using hydrogen and catalysts to convert middle boiling range or residual products into lighter products was developed in the 1960's.

Beginning in the late 1970 's, the configuration of a refinery reflected the influence of both international events and do-

$s$ Refinery configuration is a term that refers to the various types of processing units located at a refinery. 
Table 5.1 U.S. Operable Refining Capacity as of January 1 (Thousand barrels per calendar day)

\begin{tabular}{|c|c|c|}
\hline Year & Number of Refineries & Crude Oil Distillation \\
\hline 1970 & 276 & 12,021 \\
\hline 1975 & 290 & 14,961 \\
\hline 1980 & 319 & 17,988 \\
\hline 1985 & 223 & 15,659 \\
\hline 1990 & 205 & 15,572 \\
\hline 1995 & 175 & 15,434 \\
\hline 1996 & 170 & 15,333 \\
\hline 1997 & 164 & 15,452 \\
\hline
\end{tabular}

Sources: 1970-1995 and 1997, Energy Information Administration, Petroleum Supply Annual, Volume 1, Table 36; 1996: Petroleum Supply Annual, 1996, Volume 2, p. 183.

mestic policies. High quality gasoline blendstocks were needed to meet the increasing demand for unleaded motor gasoline, prompted by environmental concerns. Light, sweet oils produced by certain members of the Organization of Petroleum Exporting Countries (OPEC) were especially in demand, because they require less severe processing than heavy, sour oil to produce high quality motor gasoline blendstocks.

Federal Government price controls set in place in the early 1970's gave a clear economic advantage to refineries that had access to low cost domestic oil. The federally administered "Crude Oil Entitlements Program" was implemented in 1975 to distribute oil supplies among refiners. This program included features which, in effect, provided a subsidy for small refining companies, many of which had simple "topping" facilities and little or no downstream processing capability. (A simple "topping" refinery will have a distillation tower, and possibly a reformer and some sulfur treating capability, while complex refineries will have more extensive downstream facilities.) A refiner who had access to light crude oils needed only a distillation tower to produce motor gasoline. Therefore, many simple refineries sprang up across the country, most notably in the Gulf Coast area. However, the end of the Crude Oil Entitlements Program and decontrol of crude oil prices in 1981 eliminated special cost treatment for small refiners, and many of these less complex refineries, as well as older, inefficient plants, shut down their operations.

The number of petroleum refineries in operation dropped sharply in 1981, as 23 facilities closed and 47 others temporarily halted production, mainly as a result of the end of the small refiners' subsidies (Table 5.1). The largest loss in crude oil distillation capacity ${ }^{6}$ occurred in 1982, when 43 refineries closed. Much of the loss in distillation capacity was permanent; however, additions to downstream capability offset the closings. Since 1980, the refining industry's emphasis has shifted from increasing crude oil distillation capacity to investment in downstream charge capacity ${ }^{7}$, thereby increasing overall refinery complexity (Table 5.2). This transition began several years before the passage of the Clean Air Act Amendments in 1990 as a result of increased demand for lighter, cleaner products that have to be produced from increasingly heavier and more sour crude oils.

Downstream charge capacities do not necessarily measure a refinery's ability to produce a given product, because product mix is determined by many factors. Refiners are able to estimate production capacity (Table 5.3 ) figures for certain products under maximum operating conditions; that is, if all the process units that produce a given product were running at full capacity and were focused solely on production of that product. Isomer production capacity more than quadrupled between 1981 (131 thousand barrels per stream day) and

Table 5.2 U.S. Operable Refining Downstream Capacity as of January 1 (Thousand barrels per stream day)

\begin{tabular}{|c|c|c|c|c|c|c|c|c|c|}
\hline Year & $\begin{array}{c}\text { Vacuum } \\
\text { Distillation }\end{array}$ & Coking & $\begin{array}{c}\text { Other } \\
\text { Thermal } \\
\text { Cracking }\end{array}$ & $\begin{array}{c}\text { Catcracking } \\
\text { Fresh* }\end{array}$ & $\begin{array}{c}\text { Catcracking } \\
\text { Recycle }\end{array}$ & $\begin{array}{c}\text { Hydro- } \\
\text { Cracking }\end{array}$ & $\begin{array}{c}\text { Hydro- } \\
\text { Treating }\end{array}$ & $\begin{array}{c}\text { Catalytic } \\
\text { Reforming }\end{array}$ & $\begin{array}{c}\text { Fuels Solvent } \\
\text { Deasphalting }\end{array}$ \\
\hline 1970 & NA & 837 & 641 & 4,212 & NA & 515 & NA & 2,501 & NA \\
\hline 1975 & NA & 1,021 & 413 & 4,599 & NA & 801 & NA & 3,469 & NA \\
\hline 1980 & 6,381 & 1,068 & 496 & 5,310 & 443 & 864 & 4,616 & 3,970 & NA \\
\hline 1985 & 6,998 & 1,407 & 451 & 5,232 & 507 & 1,053 & 8,897 & 3,750 & NA \\
\hline 1990 & 7,245 & 1,549 & 559 & 5,441 & 314 & 1,282 & 9,537 & 3,896 & 279 \\
\hline 1995 & 7,248 & 1,785 & 338 & 5,583 & 169 & 1,386 & 10,916 & 3,867 & 251 \\
\hline 1996 & 7,314 & 1,842 & 311 & 5,599 & 169 & 1,385 & 11,050 & 3,852 & 281 \\
\hline 1997 & 7,349 & 1,910 & 139 & 5,595 & 155 & 1,388 & 11,041 & 3,727 & 275 \\
\hline
\end{tabular}

*Prior to 1980 , includes both fresh and recycle catcracking.

$\mathrm{NA}=$ Not Available

Italics $=$ Estimates are reported projected capacities.

Source: Energy Information Administration, Petroleum Supply Annual, Volume 1, Table 41.

6 Crude oil distillation capacity is generally measured in terms of "calendar days," or the maximum amount of input that can be processed during a 24-hour period with certain limitations. Some downstream capacities are measured in terms of "stream days," or the amount a unit can process running at full capacity under optimal crude and product slate conditions for 24 uninterrupted hours.

7 Downstream charge capacity measures the amount of inputs, or "charge," that can be processed in a particular type of downstream unit. 
Table 5.3 U.S. Operable Production Capacity as of January 1

(Thousand barrels per stream day, except where noted)

\begin{tabular}{|c|c|c|c|c|c|c|c|c|}
\hline Year & Alkylates & Aromatics & $\begin{array}{c}\text { Asphalt } \\
\text { \& Road Oil }\end{array}$ & Isomers & Lubricants & $\begin{array}{c}\text { Marketable } \\
\text { Petroleum Coke }\end{array}$ & $\begin{array}{c}\text { Hydrogen } \\
\text { (Million Cubic } \\
\text { Ft.Day) }\end{array}$ & $\begin{array}{c}\text { Sulfur } \\
\text { (Short Tons/Day) }\end{array}$ \\
\hline 1970 & 893 & NA & NA & NA & NA & NA & NA & NA \\
\hline 1975 & 1,106 & NA & NA & NA & NA & NA & NA & NA \\
\hline 1980 & 951 & $434^{*}$ & 766 & NA & 236 & 246 & 1,569 & NA \\
\hline 1985 & 917 & 215 & 767 & 219 & 243 & 424 & 2,572 & NA \\
\hline 1990 & 1,030 & 290 & 844 & 456 & 232 & 341 & 2,607 & 24,202 \\
\hline 1995 & 1,105 & 285 & 846 & 502 & 217 & 427 & 3,139 & 24,885 \\
\hline 1996 & 1,122 & 286 & 850 & 505 & 217 & 428 & 3,204 & 26,014 \\
\hline 1997 & 1,120 & 288 & 872 & 577 & 244 & 458 & 3,052 & 26,466 \\
\hline
\end{tabular}

*Includes isomerization.

$\mathrm{NA}=$ Not Available

Italics = Estimates are reported projected capacities

Source: Energy Information Administration, Petroleum Supply Annual, Volume 1, Table 42.

1997 in response to increasing demand for high octane unleaded gasoline blendstocks.

\section{Quality of Crude Oil Input to U.S. Refineries}

The added downstream capacity and treatment processes increased the refiners' flexibility, enabling them to produce a mix of finished products from a wide range of domestic and foreign crude oils. This reduced dependence on the more expensive high gravity, low-sulfur oils imported from the Middle East.

In 1977 , Persian Gulf Nations ${ }^{8}$ (sources for many high quality crude oils) supplied 37 percent of total U.S. crude oil imports. However, since 1990 , the supply sources for U.S. crude imports have shifted toward Latin America. Imports from Latin American countries nearly doubled from 1990 to 1997. During 1997, crude oil imports from Latin American countries supplied 41 percent of total U.S. crude imports, while the Persian Gulf supplied 20 percent. This change in supply sources can, in large measure, be attributed to the fact that Venezuela and Mexico have become heavily involved in the U.S. refining business. In recent years, the Venezuelan state oil company (PDVSA) and the Mexican state oil company (PEMEX) acquired 1.2 million barrels per day of U.S. crude oil distillation capacity. After making these acquisitions, both companies invested in process upgrading to handle the heavy-sour Venezuelan and Mexican crude oils.

As crude oil imports from the Persian Gulf declined, the average gravity of imported crude oil dropped from about 34 degrees API in the late 1970's to 30 degrees API in 1997. This is because crude oils from Latin America, particularly
Mexican, Venezuelan and Guatemalan oils, are much heavier than Persian Gulf crudes. In 1997, the average weighted API gravity of Persian Gulf crude imports was about 32 degrees, compared to 26 degrees for the average of imports from Latin America. (The higher the gravity measured on the API scale, the lighter the crude oil.) The sulfur content of imported crude oil has risen from less than one percent in the late 1970 's to about 1.6 percent in $1997 .^{\circ}$ As the sources of crude oil continue to shift, changes in the characteristics of crude oil inputs will continue to shape the configuration of U.S. refineries.

\section{Refinery Capacity and Utilization}

Because crude oil distillation is the first phase of refinery operations and provides the feedstocks (inputs) for many other processes, crude oil distillation capacity, ${ }^{10}$ or the amount of crude oil that can be processed in a refinery's atmospheric distillation units, is one measure of the refining industry's ability to satisfy demand. While refinery distillation capacity has generally paralleled product demand, the two do not always move in tandem. Changes in demand stimulate changes in refinery capacity as the industry adds, closes, or modifies refineries to adjust to market requirements. The lag between changes in demand and changes in capacity reflects the lead time required to change the configuration of existing facilities.

As of January 1, 1997, the 164 petroleum refineries in operation in the United States, ranged in size from small refineries able to process 1,000 barrels of crude oil per day in their crude oil distillation units to those able to process more than 400,000 barrels per day. Their combined crude oil distilla-

8 Includes Bahrain, Iran, Iraq, Kuwait, Qatar, Saudi Arabia, and the United Arab Emirates.

9 Energy Information Administration, Form ElA-814 "Monthly Imports Report."

10 "Crude oil distillation capacity" refers to capacity that is "operable", i.e., actually in operation; not in operation or under active repair, but able to be brought on line within 30 days; or undergoing repairs that can be completed within 90 days. Operable capacity is subdivided into "operating" or "idle" capacity according to current status. 
Table 5.4 Top Ten Petroleum Refining States as of January 1, 1997

\begin{tabular}{|l|c|c|}
\hline \multicolumn{1}{|c|}{ State } & $\begin{array}{c}\text { Number of } \\
\text { Operable } \\
\text { Refineries }\end{array}$ & $\begin{array}{c}\text { Operable Crude Oil } \\
\text { Distillation Capacity } \\
\text { (Thousand } \\
\text { Barrels/Day) }\end{array}$ \\
\hline Texas & 30 & 4,043 \\
\hline Louisiana & 19 & 2,430 \\
\hline California & 24 & 1,911 \\
\hline Illinois & 6 & 948 \\
\hline New Jersey & 6 & 645 \\
\hline Washington & 7 & 583 \\
\hline Pennsylvania & 6 & 576 \\
\hline Ohio & 4 & 509 \\
\hline Indiana & 2 & 432 \\
\hline Oklahoma & 5 & 408 \\
\hline Subtotal & 109 & 12,485 \\
\hline U.S. Total & 164 & 15,452 \\
\hline
\end{tabular}

Note: Total capacity may not equal sum of components due to independent rounding,.

Source: Energy Information Administration, Petroleum Supply Annual 1996, DOE/EIA-0340(96), Table 36.

tion capacity totaled 15,452 thousand barrels per calendar day.

Nearly one-half of the Nation's crude oil distillation capacity resides in the Gulf Coast region, which holds over one-third of the petroleum refineries in the United States. Most of the region's refineries are located in Texas and Louisiana. Texas has 30 refineries, with a combined crude oil distillation capacity of 4.0 million barrels per day, and Louisiana has 19 refineries with 2.4 million barrels per day of atmospheric distillation capacity. California's 24 refineries add about 1.9 million barrels of crude oil distillation capacity. The "top ten" refining States, those with the highest individual crude oil distillation capacity, account for 81 percent of the U.S. total (Table 5.4).

The U.S. refining industry's ability to meet short-term increases in demand can also be measured by the rate at which operable distillation capacity is utilized. The refinery utilization rate is expressed as a percent and represents gross inputs to crude oil distillation units divided by operable capacity. The utilization rate fluctuates as refinery operations adjust to changes in demand. It reflects changes in refinery operations more rapidly than capacity changes do. For example, capacity expansions begun in response to high demand levels through the early and mid-1970's continued to come on line even after demand peaked in 1978. At the same time, gross inputs to distillation units leveled off and turned downward in response to declining demand. As a result, refinery utilization declined steadily from 1978 to 1981, evidencing a slowdown in refining activity that was not reflected in capacity figures until 1982.

However, during the 1980 's, the U.S. refining industry experienced a net loss of 120 refineries and approximately 3 mil- lion b/d of operable capacity. Conversely, there was a steady rise in U.S. demand for petroleum products after 1983. Consequently, the amount of gross inputs to refineries rose steadily every year since then. As a result of the continual loss of capacity every year, and in response to rising demand for refined petroleum products, the average annual refinery utilization rate increased from 69 percent in 1981 to 95 percent in 1997.

Refinery yield represents the ratio of a particular finished product to inputs of crude oil and net inputs of unfinished oils (Figure 5.2). Improvements in process technology and expansion of downstream process capability can lead to increases in the yields of light products. On the other hand, increased use of heavier crude oils and changes in the mix of products can result in a decrease in light-product yields. Also, more stringent product specifications can require additional processing, which results in additional yield loss. However, process technology improvements have enabled refiners to avoid light-product yield declines and achieve slight yield improvement. Refinery yields for finished motor gasoline and distillate fuel oil, the two major refined products, have remained fairly steady throughout the 1990's. Finished motor gasoline yield in 1997 was 46 percent and distillate fuel oil yield was 23 percent. Residual fuel oil yields dropped from 7 percent in 1990 to 5 percent in 1997. Yields for petroleum coke and liquefied petroleum gases each grew a percentage point between 1990 and 1997 to 5 percent.

\section{Figure 5.2 Product Yield from a Barrel of Crude Oil, 1997}

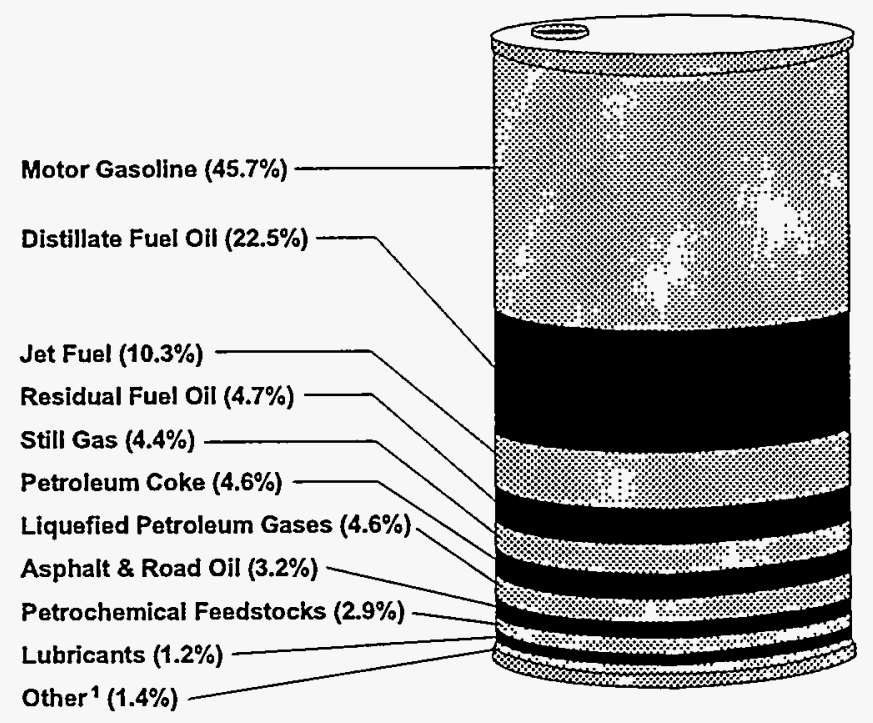

\footnotetext{
${ }^{1}$ Includes kerosene, special naphthas, aviation gasoline, waxes, and miscellaneous products.

Note: Components do not add to 100 percent due to independent rounding and because of processing gain (an increase in volume that occurs during refining).

Source: Energy Information Administration, Petroleum Supply Annual 1997, DOE/EIA-0340(97)/1, Table 19.
} 


\section{UPG Sources and Processing}

Many terms are used to denote the rarious hydrocarbon compounds that are found in both the gaseous and tiquid states. In some cases these terms are used interchangeably but for the most part the different ternis refer to different compounds at different stages of processing.

Liquefied petroleum gases ( $\mathrm{HPG}$ ) noliude ethane ethylene propane, propytene, nomal butane butylene, ana isobütan produced at refinenes and natural gas processing plants otherplants that separate rawnatural gas plant liquids into ther various constifuents or fractions; in a distillatton process known as fractionation; are called ffractionation plants" on fractionators? propane bitane, and mixtures consistong marnly of these two conpounds are the most common LPG's.

Natural gas ts a mixture of hydrocarbon compounds existing in the gaseous state or in solution with oil in natural underground resetvours Hydrocarbon lfquids condetrsed from Wwet natural gas coming from the well are known as natural gas liquids (NGL s), NGL s are recovered at gas processing plants They include the lighter tiquids (ethane, propane and butane, and mixtures of these compounds) as well as the hearier pentanes plus (isopentane, nautral gasoline, and plant condensate) Nost patural gas processing plants yield "unfractionated streans; on NGL mixes thatare Iater separated into their component parts at fractionators to yeld ethane propane butane isobutane and pentanes plus. Once the liquids have been removed and the natiral gas is ready for consumption, is known as " dry" natural gas

Liquefied refinery gases (LRG's) are $1 \mathrm{RG}$ 's produced at refineries Refineries use large quantitíes of NGE 's from

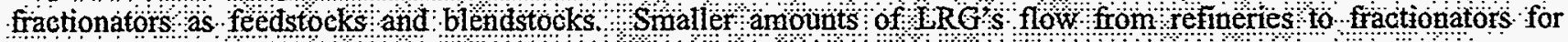
processing.

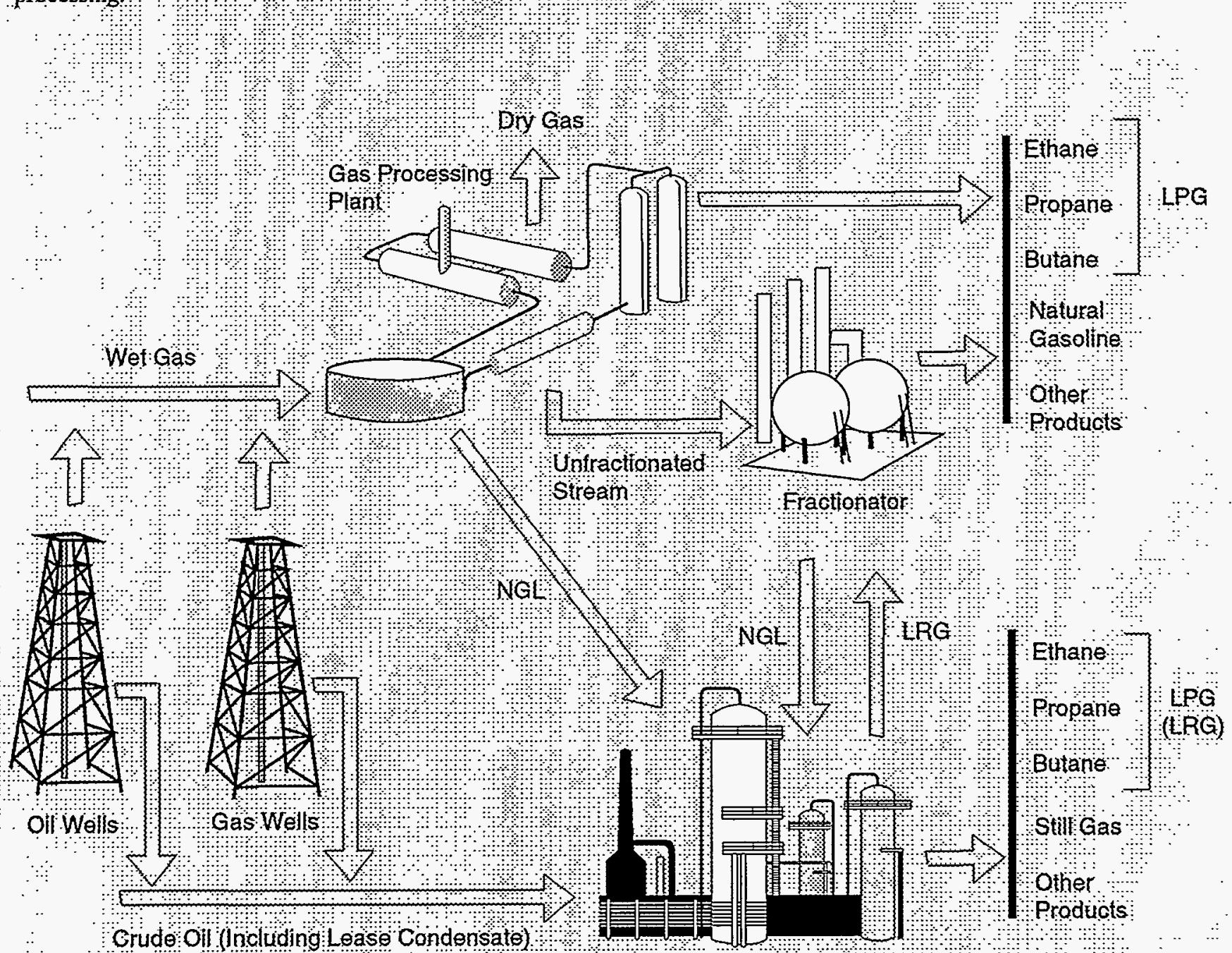

Refinery 
Refinery configuration is constantly changing to meet current requirements. Changing quality of crude oil inputs and changing product requirements will continue to stimulate technological advances and modifications in refinery configuration. Environmental requirements for cleaner burning fuels and cleaner refinery processes have been foremost among the factors that have influenced refinery configuration during the last decade. Innovations in catalyst design and refinery process units will continue to allow greater flexibility in processing heavy residual oils. Newly developed catalysts will also help refiners meet environmental standards for sulfur in final products and in refinery emissions. Requirements for specialized hydrocrackers, hydrotreaters, and other downstream units are likely to increase as refinery configurations adapt to increasingly stringent product specifications. 


\section{Motor Gasoline Octane Enhancement}

Motor gasoline is a complex mixture of relatively volatile hydrocarbons that have been blended to form a fuel suitable for use in spark-ignition internal combusion engines. Various gasoline blends differ in properties that affect engine performance, such as octane and volatility. The octane rating measures the anti-knock properties of a motor gasoline. (A research octane number (RON) based on performance under research test conditions and a motor octane number (MON) based on more severe operating conditions are averaged to produce the road octane number $(R+M) / 2)$ that is posted on the gasoline pump.) As automobile engines underwent design changes to increase power and efficiency, they required higher octane gasolines to prevent uneven combustion known as "engine knock." Volatility, (evaporative tendency) measured by the Reid Vapor Pressure (RVP), affects engine starting and performance. (RVP represents the vapor pressure of the liquid at 100 degrees Fahrenheit expressed in pounds per square inch.) Gasoline blends are adjusted to raise the RVP in winter, which allows the gasoline to vaporize readily in the combustion chamber to provide for easy starting. The RVP is lowered in summer so the gasoline will not vaporize in the fuel system causing a condition known as "vapor lock".

Early gasolines produced simply by atmospheric distillation of crude oil did not satisfy the higher octane requirements of the newer engines, so other methods were employed to boost octane; namely, greater use of complex "downstream" refining processes, and the use of additivies such as lead. Because of lead's toxicity, its use in automotive fuels was first restricted with the passage of the Clean Air Act of 1970 requiring the design and manufacture of automobiles that could run on low-lead and unleaded fuel and establishing a schedule for reducing the use of lead in gasoline. As environmental concerns grew, the Environmental Protection Agency (EPA) continued to tighten lead level restrictions. By January 1, 1986 , the lead content was limited to 0.1 gram per gallon, although the phase-in of EPA's regulations permitted refiners to use "lead credits" earned for gasoline containing less than the maximum amount of lead allowed to offset production of gasoline that exceeded the lead limit until December 31, 1987. The Clean Air Act Amendments of 1990 completely banned the use of lead in motor gasoline after December 31, 1995.

The gradual elimination of lead increased the use of other additives, including compounds produced in refineries, such as butane and the aromatics benzene, toluene, and xylene, to enhance gasoline octane ratings. Other additives used to boost octane ratings, termed "oxygenates" because they raise the oxygen level of gasoline, include alcohols such as ethanol and ethers such as methyl tertiary butyl ether (MTBE).

Some of these blendstocks have various undesirable environmental properties. For example, the addition of butane to gasoline increases its volatility, increasing the loss of unburned hydrocarbons from the fuel tank or carburetor. Because of the environmental hazards associated with the escape of hydrocarbons through evaporation, EPA promulgated new regulations in 1989 to restrict gasoline volatility in the summer months. Later EPA regulations and the Clean Air Act Amendments of 1990 further restricted volatility beginning in 1992. The Clean Air Act Amendments also required the use of "reformulated" gasoline to reduce the formation of ground level ozone in certain metropolitan areas beginning in 1995. Beginning in November 1992, gasoline sold in areas that exceed air quality standards for carbon monoxide are required to contain specific levels of oxygen to reduce carbon monoxide emissions in the wintertime. As environmental concerns grow, oxygenates (alcohols and ethers) are becoming a larger component of gasoline supply. Presently, ethanol and MTBE are the most widely used oxygenates.

For the most recent data on refinery inputs, production, and capacity utilization, look for the current issues of the Weekly Petroleum Status Report and the Petroleum Supply Monthly on the "Petroleum" page of EIA's website at : http://www.eia.doe.gov/. Refinery crude oil distillation and downstream capacity data are published by State and company in the Petroleum Supply Annual, Volume 1, also on the "Petroleum" page. These data are available every other year (i.e., 1996, 1998, etc). In addition, historical series for the total U.S. are available in the Annual Energy Review on the "Historical" page of our website. World refinery production and world refinery capacity can be found in the International Energy Annual on the "International" page. 


\section{Transportation and Storage}

Storage facilities and four major transportation modes-water, highway, rail, and pipeline-form a system which moves crude oil from wells to refineries, and distributes refined products to final consumers. In the United States, the sources of oil have, over time, moved farther and farther from the major consuming areas. Distance, geography, technology, and economics all influence the types and amounts of transportation and storage used.

The first crude oil produced in the United States was collected in wooden barrels and transported to the refinery by boat, train, or horse drawn wagon. Barrels (equivalent to 42 U.S. gallons) are still the standard measure for petroleum. At first, large quantities of oil were stored in oblong wooden boxes or in pits dug in the earth. ${ }^{1}$ In the 1860 's, storage methods improved rapidly; first, when circular wooden tanks were developed and again, shortly thereafter, when riveted wrought iron tanks were first built. These remained the primary means of storing crude oil until after the turn of the century when steel storage tanks were introduced.

The first successful pipelines were constructed in the middle 1860 's. They were short and used mainly to connect producing wells with water or rail transportation facilities. Longer pipelines were soon being built and began to compete with long-distance rail transportation. Controversy marked the late 1800's as the different transportation modes fought for market share. Eventually, pipelines won some protection through the courts. Rail continued to be an important means of transporting petroleum, especially refined products, until about 1930 when the technology for shipping more than one product through a single pipeline was developed.

Before World War II, oil-carrying ships, known as tankers, were a chief means of transporting petroleum products from the refineries on the Gulf Coast to the Nation's largest consuming areas on the East Coast. But during the war, the sinking of more than 150 tankers in submarine attacks and the perceived threat to remaining tankers led to a surge in building and use of pipelines.

A resurgence of domestic water transportation of petroleum followed the beginning of significant Alaskan production in the late 1970's. By 1983, water transportation of petroleum peaked and accounted for nearly 52 percent of all domestic transportation of petroleum (Figure 6.1). However, by 1995 , water transportation of petroleum had declined to about 38 percent of all domestic petroleum transportation. In contrast,

\section{Constructing Pipelines}

After several attempts to buttd cast iron pipelines the first suceessful plpelines were constricted of wrought iron in the middle $1860^{\circ}$ s. In 1895 stel pipe was introduced several people, armed with lange wrenches called tongs, were needed to screw together the lengths of steel pipe Advance ments n wefding technology in the I $920 \% \mathrm{~s}$ led to anprovements in the construction of both storage tanks and ppelines: Today, phesections are welded together, either by hand or by autornatic

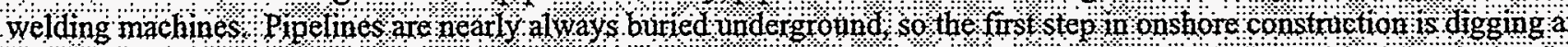
french Machines suspend pipe sections over the ditch white they are welded, Bending machines can bend fle pype to fit the contour of the land f necessary Before burying the pipetine $\mathrm{s}$ coated With 2 corrosion inhibitor, then wrapped in

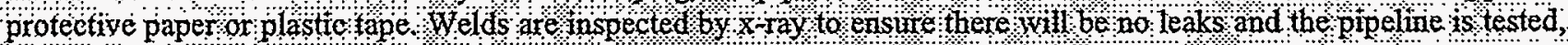
usually by running water through it ander pressure

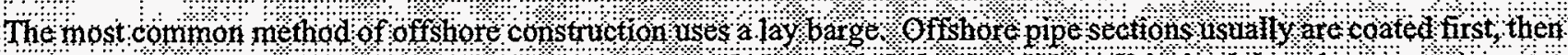

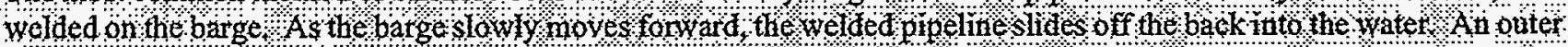

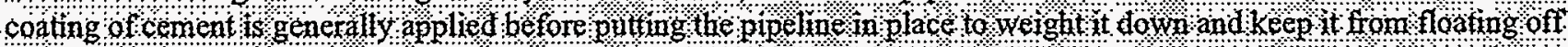
the se bottom Anothen type of offshore construction nses a feel Garge Which camres aready yelded pipe owound on a farge spool or reel $\mathrm{As}$ the barge moves wong the ptpe is turreded and tet out the back of the barge carefully sothe metal

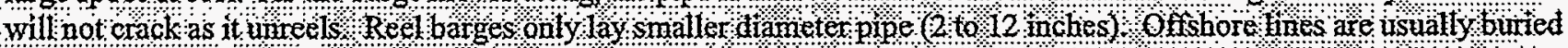
after they fave been thid on the ooean floon

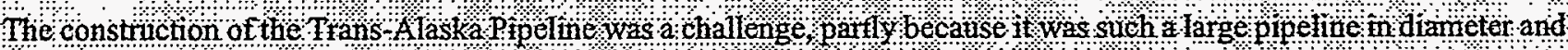

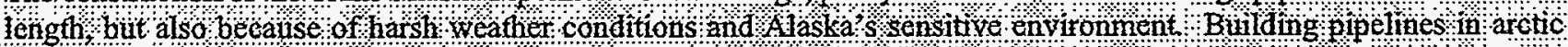

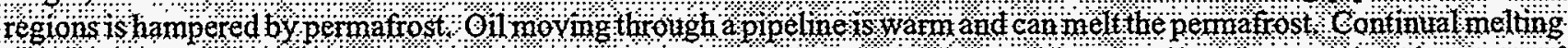

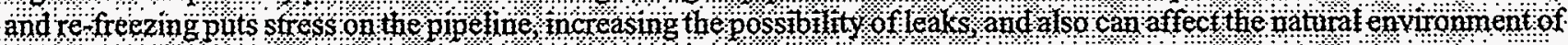

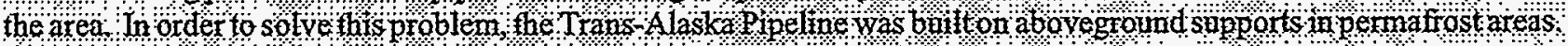

1 A. Marks, Petroleum Storage Principles (Tulsa, Oklahoma: PennWell Books, PennWell Publishing Company, 1983), p.4.

Petroleum: An Energy Profile, 1999 
Figure 6.1 Petroleum Transportation by Mode of Travel, Selected Years 1975-1995

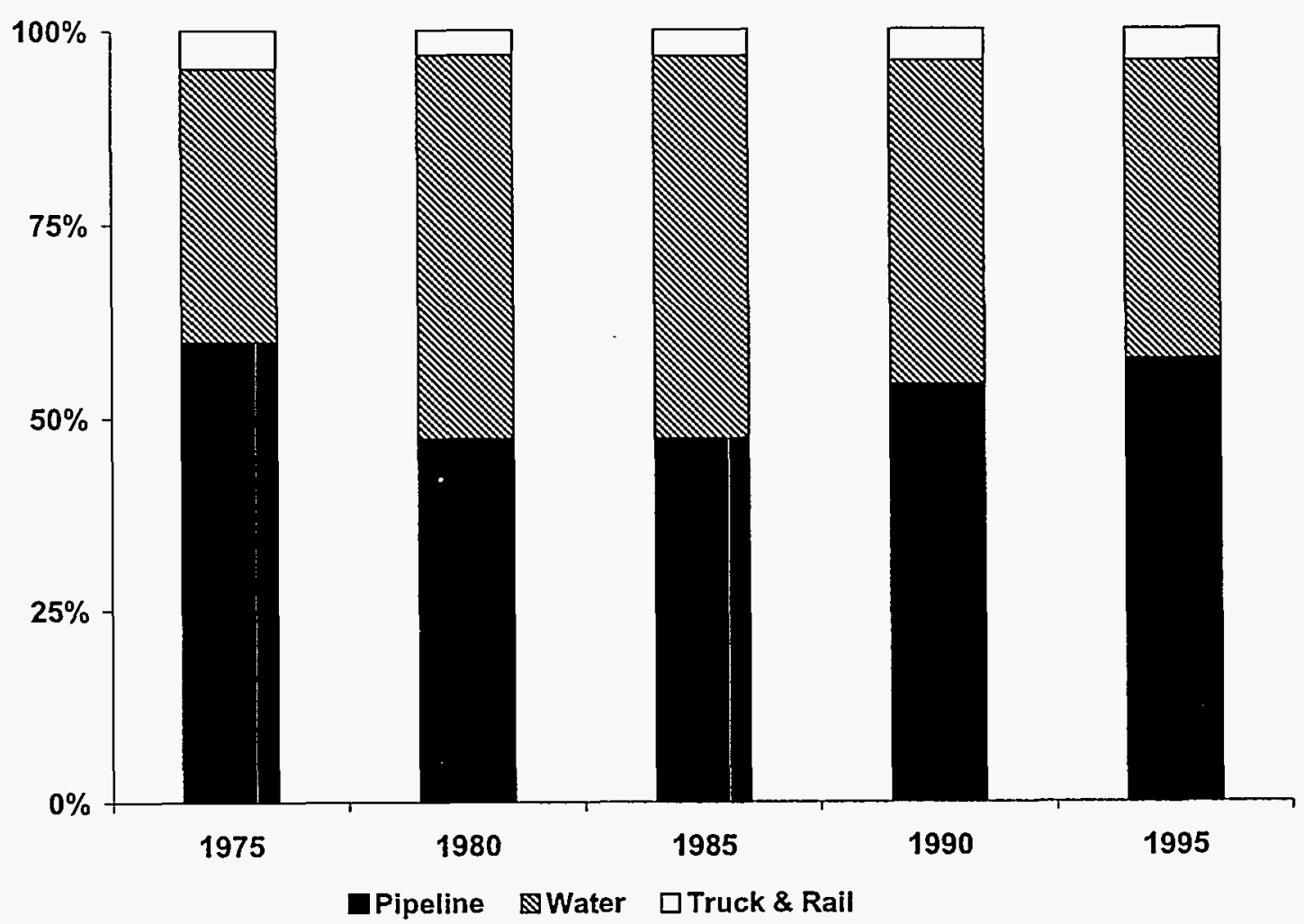

Sources: 1975-1990: Association of Oil Pipelines, "Shifts in Petroleum Transportation." 1991-1995: Eno Transportation Foundation, Inc., Transportation in America.

pipelines as a means of transporting petroleum grew steadily over this period, and by 1995 , accounted for nearly 58 percent of all petroleum transported. Altogether, crude oil and refined products were carried by pipeline, water carriers, trucks, and railroads over 1,045 billion ton-miles in $1995 .^{2}$

Most crude oil arrives at the refinery via pipeline (Table 6.1). Trucks are mainly used to deliver products from bulk storage to retail outlets or final consumers, although they may occasionally transport crude oil from very remote field storage sites. Railroads carry only a small amount of petroleum, generally products.

Storage facilities are located along transportation routes to accommodate the different rates at which various transportation modes can handle oil and refined products. Gathering smaller volumes into larger batches or dividing up large batches allows the cargoes to meet the capacities of the next transportation mode. Storage facilities are also found at refineries and at wholesale and retail marketing facilities where products are stored in bulk prior to being sold to consumers in smaller amounts.

\section{Transportation}

The shipment of Alaskan crude oil comprises a significant portion of the U.S. petroleum transportation system. Most
Table 6.1 U.S. Refinery Receipts of Crude Oil by Method of Transportation and Source, 1996 (Thousand Barrels)

\begin{tabular}{|c|c|}
\hline Transport Method/Source & Receipts \\
\hline \multicolumn{2}{|l|}{ Pipeline } \\
\hline Domestic . . . . . . . $\ldots$ & $1,849,835$ \\
\hline Foreign . . . . . . . . . . & 923,008 \\
\hline \multicolumn{2}{|l|}{ Tanker } \\
\hline Domestic. . . & 482,840 \\
\hline Foreign. . . & $1,813,976$ \\
\hline \multicolumn{2}{|l|}{ Barge } \\
\hline Domestic . . . . . . . . . . . & 83,764 \\
\hline Foreign . . . . . . . . . . & 11,644 \\
\hline \multicolumn{2}{|l|}{ Tank Car } \\
\hline Domestic. . & 6,040 \\
\hline Foreign. . . & 0 \\
\hline \multicolumn{2}{|l|}{ Trucks } \\
\hline Domestic. & 69,492 \\
\hline Foreign & 0 \\
\hline \multicolumn{2}{|l|}{ Total } \\
\hline Domestic. & $2,491,971$ \\
\hline 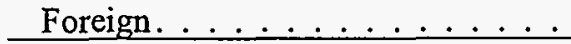 & $2,748,628$ \\
\hline
\end{tabular}

Source: Energy Information Administration Petroleum Supply Annual, 1996, Volume 1, Table 46.

2 American Petroleum Institute, Basic Petroleum Data Book, Volume XVIII, Number 2, July 1998, Table 2. 
Alaskan oil is transported via the Trans-Alaska Pipeline more than 800 miles, from the oil fields in northern Alaska to the port of Valdez on Alaska's southern coast. From Valdez, the crude oil is carried by tankers to ports on the West Coast. In addition to transporting crude oil from Alaska, tankers bring in foreign imports and carry refined products between the Gulf Coast and East Coast.

Most crude oil shipped within the continental United States occurs via pipeline from the Gulf Coast to the Midwest region, while tanker and barge shipments of crude oil account for only a small portion that occurs exclusively between the Midwest and East Coast regions. Conversely, tanker and barge shipments of petroleum products account for a much larger share of the overall movement of petroleum products within the continental United States, although pipelines continued to be the primary means of shipping petroleum products to end-use markets. Most petroleum products shipped via pipelines occur between the Gulf Coast and Midwest and East Coast regions (Figure 6.2).

Ocean-going ships were used to transport crude oil as early as 1861, when barrels of oil were carried on a ship from the United States to England. Within just a few years, tankers in which the hull serves as an oil tank were built. ${ }^{3}$ In modern tankers, subdivided hulls allow more than one product to be carried on each trip and prevent the liquids from shifting enough to destabilize the ship. Today's tankers range in size from about 70,000 barrels of capacity to over 3.5 million barrels. ${ }^{4}$ Supertankers about one and a half times the size of the standard World War II tanker, were introduced in the 1950's. By the 1960's they had been surpassed in size by "very large crude carriers" (VLCC's). In 1979, "ultra large crude carriers" (ULCC's) began carrying oil. ${ }^{\text {s }}$

Attention focused on the environmental hazards of tanker transport when the Exxon Valdez ran aground off the coast of

Figure 6.2 Inter-Regional Movement of Crude Oil and Petroleum Products by Water and Pipeline, 1997 (Thousand Barrels per Day)

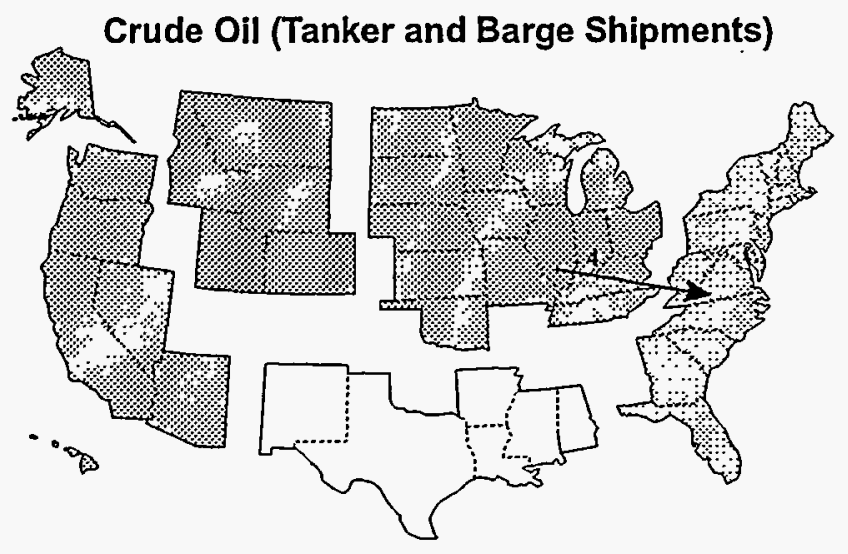

Petroleum Products (Tanker and Barge Shipments)
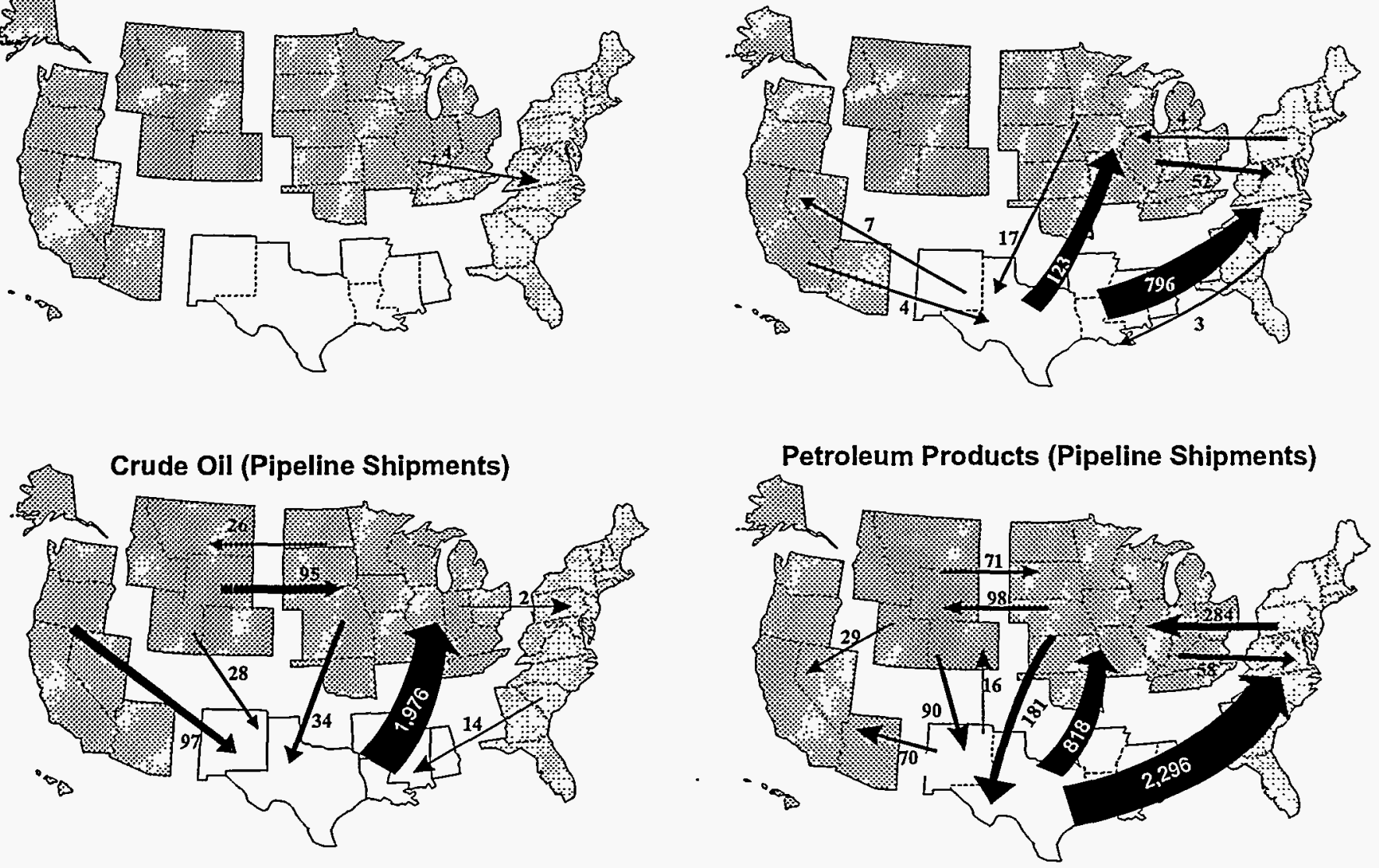

Note: Arrows vary in size to show the relative difference in inter-regional shipments.

Source: Energy Information Administration, Petroleum Supply Annual, 1997, DOE/EIA-0340(97)/1.

3 Energy Information Administration, Petroleum Supply Monthly (December 1983), DOE/ELA-0109(83/12), “An Overview of Petroleum Transportation," p.x.

4 The capacity of oil tankers is expressed in deadweight tons. This measure refers to the lifting capacity of a ship in long tons $(2,240$ pounds or 1.016 metric tons). The volume of petroleum that can be carried depends on the characteristics of the product as well as tanker size, but one deadweight ton is equivalent to about 7 to 8 barrels of crude oil.

5 Supertankers are tankers with capacity above 24,000 deadweight tons. VLCC's range in size from 160,000 to 319,999 deadweight tons and ULCC's are those tankers with capacity of 320,000 or more deadweight tons. Source: M. Champness and G. Jenkins, Oil Tanker Databook 1985 (London: Elsevier Applied Science Publishers, 1985), Glossary. 
Alaska in 1989 , spilling some 240,000 barrels of crude oil into Prince William Sound. The Oil Pollution Act of 1990 , which was signed into law on August 18,1990, was a direct outgrowth of concern over that spill. The Act sets forth cleanup and prevention measures for oil spills and requires the gradual phase-out of single-hull tankers. Beginning in January 1995, new tankers traveling in U.S. waters (except for vessels that might respond to a spill) must have double hulls.

California has the only port (Long Beach) in the contiguous United States capable of handling the very large crude carriers, and there are no ports deep enough to accommodate the ultra large carriers. Imports carried by very large and ultra large tankers are often transferred into smaller ships before continuing to the United States. These transfers occur at deep water Caribbean ports and at seas, but the Louisiana Offshore Oil Port (LOOP) has reduced the need for transfers since it opened in 1981. The LOOP is a storage and transportation facility 18 miles offshore in the Gulf of Mexico where the water is deep enough to accommodate ultra large tankers. It consists of a platform, which serves as an operations base, and buoys. Tankers dock at the buoys where they are free to move with current and winds. Hoses connect the cargo hold of the ship to the buoy. Oil is off loaded through the hoses and buoy and runs into a 48 -inch diameter pipeline which carries it to salt cavern storage facilities in Louisiana.

In recent years, ocean-going barges have been used to move petroleum short distances between points on the Atlantic and Gulf Coasts, but barges are designed primarily for the calmer, shallower waters of inland waterways. They are used largely to transport petroleum along the Mississippi and Ohio river systems. They are also used often on inland waterways in the Gulf States and in some Northeast canals and rivers. Crude oil entering at Gulf Coast ports, if not refined there, may be moved up the Mississippi and Ohio Rivers to refineries in the Midwest. More often, however, barges transport refined products.

Barges are flat-bottomed boats that, like tankers, usually have subdivided hulls which serve as oil tanks and can carry more than one product at a time. Individual barges carry much less than tankers, up to about 30,000 barrels, ${ }^{6}$ but they are usually lashed together in groups. Most barges cannot move on their own but are pulled or, more often, pushed by towboats at speeds of about 6 miles per hour. ${ }^{7}$

Tank trucks operate throughout the United States, mostly on short-haul routes. Tank trucks for transporting petroleum products first appeared about 1915. They are the smallest of the oil carriers, being able to transport only a few hundred barrels. Some are compartmentalized to hold more than one type of product. Because of their small size, they can reach remote areas.
Railroads are used to fill gaps between other transportation modes, mainly to transport heavy products like asphalt, residual fuel oil, and lubricants, which are difficult or impossible to move through pipelines. There are two basic types of rail tank cars-pressurized and unpressurized. Pressurized cars carry very volatile products such as liquefied petroleum gases.

Pipelines serve many areas of the United States (Figure 6.3). The major long-distance pipelines are the crude oil pipelines across Alaska, crude oil pipelines running from the Gulf Coast to the Midwest, and product pipelines running from the Gulf Coast refineries to the East Coast, mainly New York and New Jersey. A recent and important addition to the pipeline system is a crude oil line running from California to Texas. New England has notably few pipelines. There are many pipelines in the Gulf of Mexico and off the California coast which connect offshore production sites with facilities on land.

Except for large tankers, pipelines are the least expensive means of transporting petroleum, and large pipelines usually are more economical to operate than small ones. The smallest pipelines are the flow lines from the wells which usually range from 2 to 6 inches in diameter."Gathering" lines, up to about 12 inches in diameter, transport crude oil from producing fields to long-distance "trunk" pipelines which are usually much larger. The Trans-Alaska and LOOP pipelines, at 48 inches in diameter, are the largest pipelines in the United States. $^{8}$

Crude oil and products move through a pipeline at up to 6 miles per hour. Pumps at the beginning and at intervals along the line provide the force to move the oil. Pump stations along the line are usually controlled by computer from one central location. The computers are also used to keep track of shipments and deliveries. Telegraph lines were used to relay information along the earliest pipelines. Today satellite communications are often used.

Before the introduction of "batching" in the 1930's, pipelines were used almost exclusively to transport crude oil. Batching enables pipelines to run several different products back to back, maintaining a continuous flow of liquid in the pipe. To minimize mixing at the interface of two products, the order in which batches enter the line is controlled. The products remain separated because of their different densities. Differences in density also signal the pipeline operator of the beginning and end of particular batches. Occasionally, batches are separated by a rubber sphere or other physical barrier.

In the United States, most oil pipelines are operated as "common carriers" which means that the pipeline owner does not take title to the oil being shipped, but simply provides the

6 S.P. Porter, Petroleum Accounting Practices (New York: McGraw-Hill Book Company, 1965), p. 371.

7 Energy Information Administration, Petroleum Supply Monthly (December 1983), DOE/EIA-0109(83/12), "An Overview of Petroleum Transportation," p.x.

8 J. L. Kennedy, Oil and Gas Pipeline Fundamentals (Tulsa, Oklahoma: Pennwell Books, PennWell Publishing Company, 1984 ), p.51. 
Figure 6.3 Petroleum Pipelines in the United States as of December 31, 1997
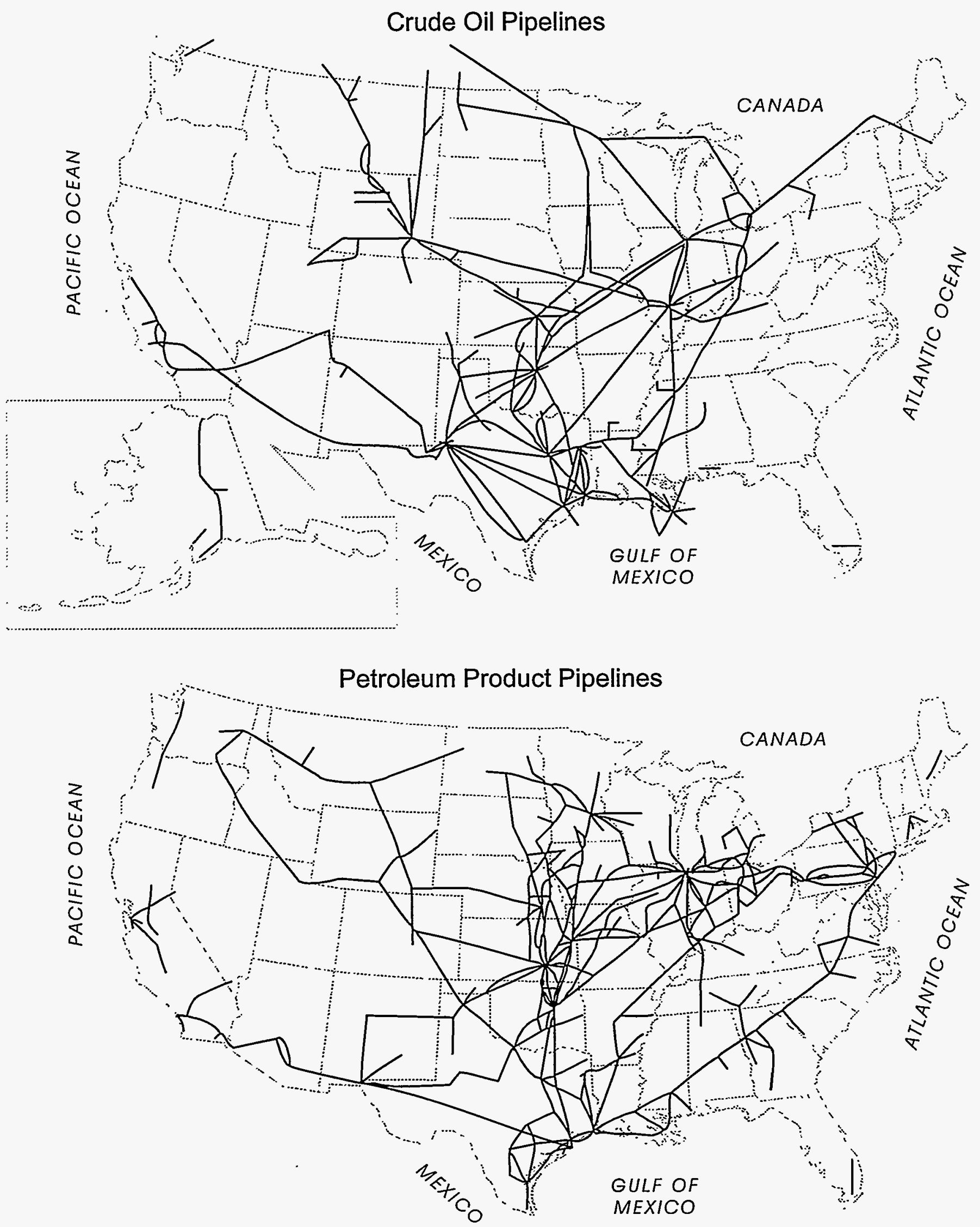

Source: National Petroleum Council, Petroleum Storage \& Transportation, 1998. 


\section{The Strategic Petroleum Reserve}

In 1975 , following the oif shortages atd resulting economie problems created by the $1973-1974$ oil embargo, Congress enacted the Energy Policy and Conservation Act which called for the Government to develop a Strategic Petroleum Reserve (SPR). The purpose of the SPR is to store crade oil which can be drawn upon to prevent shortages in domestic maxkets during a major intemuption of crude oil supplies. SPR use s designated for emergency situations such as when a disruption of imports, sabotage or a natural disaster creates: a sexere national shortage that will threafen national safety and the national economy. Onty the Bresdent has the authority to order that the SPR be used. In the event of a SPR distribution, the ot is sold to btdders in an open market.

In 1977 , the Fedetal Government began purchasing cride oil and stonting it in salt caverns $I$ SPR facitities include six

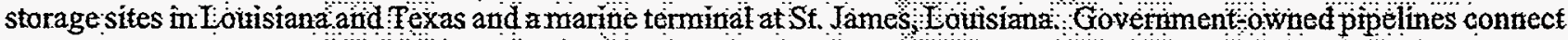
the storage sites to commerctal enude oil pipelines and narine terninats throught which the onl would be distributed. Most of the SPR crude oil has been purchased from foreign sources:

In September 1990 , the Energy Policy and Conservation Act was anended to antionize a small sale of $\mathrm{SPR}$ oil to test the Reserve's distribution and sales system On September 26 , the President directed the Department of Energy to conducta sale of about 5 milton barrels of SPR crude oil After receipt and evaluation of afl bids, 3.9 million barrels of crude oil were delivered to 11 purchasers between October 19 and December 2 Shortly thereafter the start of the Persian Gulf:War prompted the first emergency distribution of $S P R$ oil It Jantary 1991 , the International Enefgy $A$ gency, of which the United States is a member, agreed to aplan for relea sing some of from reserves if a war be gan Ot January 7 ; President Bush announced th 33.8 million barrets of SPR oil would be sold n conjunction with that plan Because of changing market conditions, incliding continued oil surpuîses and falling prices bids covering onty 173 million barress were eventually accepted. Most of the oil was detiyered in February and March towever, on February 11, 1999, the Secretary of Energy announce an initiative to partialty e efill the $S R R$ with federal royalty of from production in the Cenfral Gulf of Mexico. The plan was specifically designed to replace approximately 28 million barrels of oil sold from the SPR in fiscal years 1996 and 1997 largely for deficit:teduction purposes:

The SPR is tistally seen as a replacement for imports and the âmount stored is often described in terms of the number of

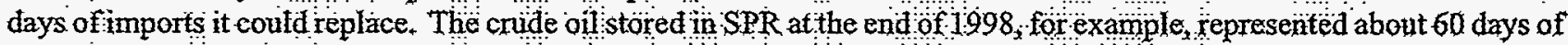
net petroleum imports. Currently, the SPR has 564 willion barrels of crude oil in storage.

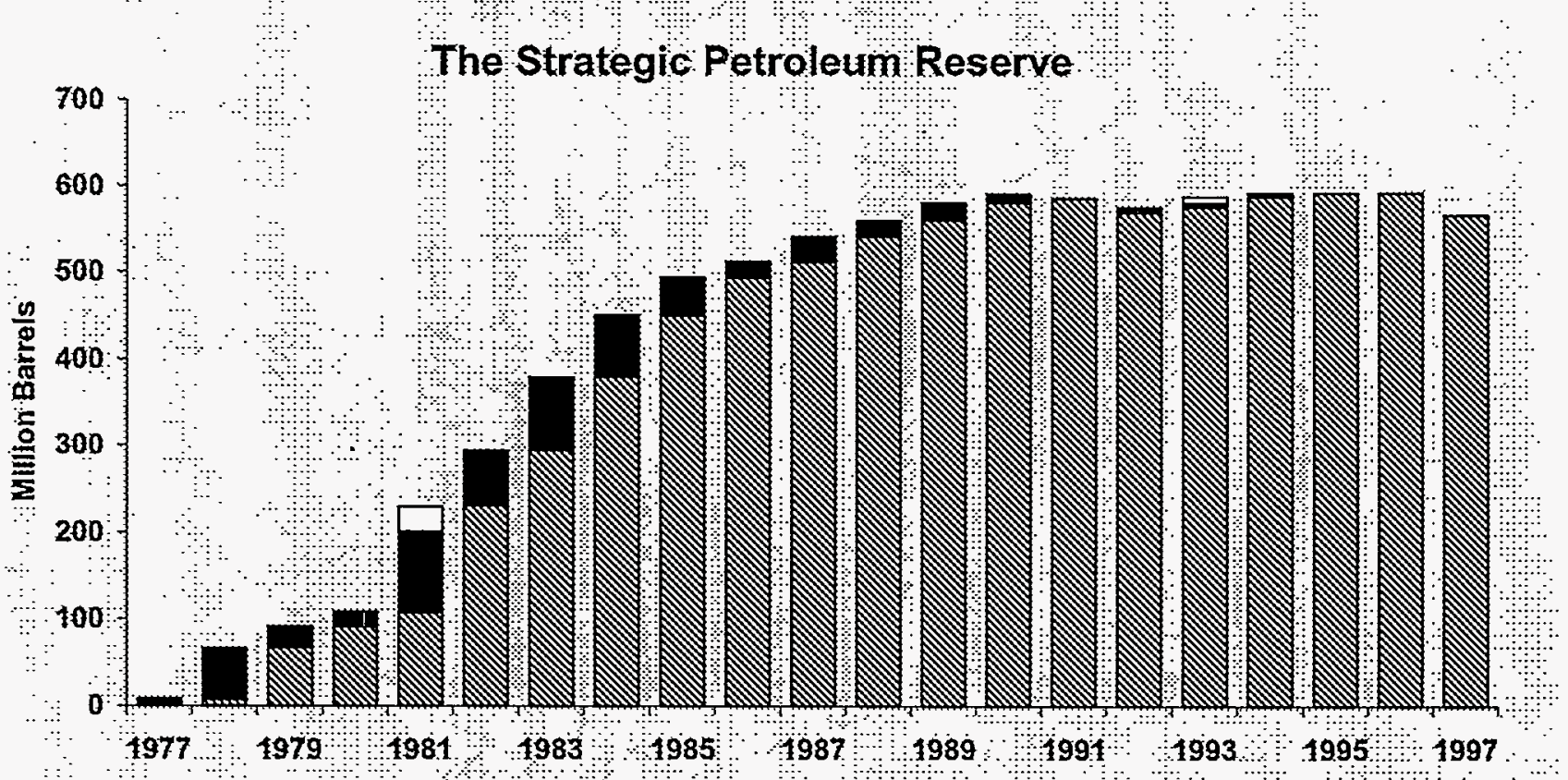

Beginning of Year Stocks Additions from Imports $\square$ Additions from Domestic Sources

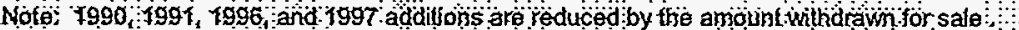

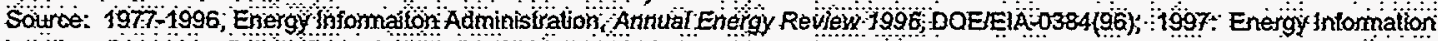

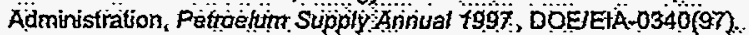


transportation service. As common carriers, pipelines must be accessible to all oil that meet their specifications, regardless of ownership, and are subject to Government regulations concerning rates and operating practices. Pipelines are also subject to environmental regulations because their construction and the possibility of leaks during operation pose a danger to animal and plant life as well as ground water.

\section{Storage}

In the producing field, most crude oil is first stored in a battery of tanks, sometimes called lease tanks, where the oil from many wells is collected. Imported oil is usually first stored at a marine terminal at the port of entry where crude oil and products are unloaded from tankers into storage to await further shipment via inland transport networks. At refineries, incoming crude oil waits in storage tanks until it can be processed; refined products are held separately in tanks until enough is accumulated for blending or shipment. Pipeline pumping stations may have storage facilities, referred to as tank farms, where crude oil or products can be detained for transfer to another line, to await repairs on the line, or to be measured and recorded (Figure 6.4). Products are often sent from the refinery to storage at bulk terminals or bulk storage plants, from which products are resold and/or distributed locally (Figure 6.5). The final two storage phases for most petroleum products are storage tanks at retail sales outlets and
Figure 6.4 U.S. Crude Oil Stocks by Storage Facility, December 31, 1997

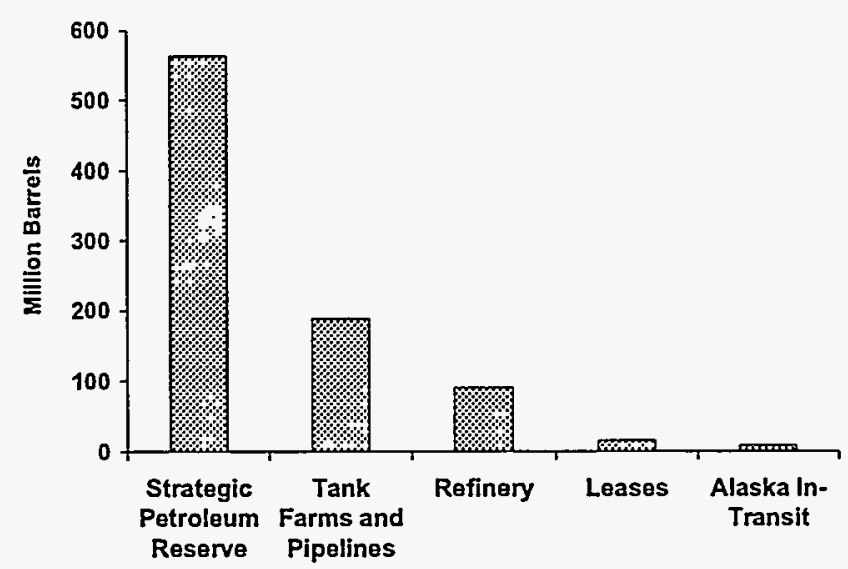

Source: Energy Information Administration, Petroleum Supply Annual 1997, DOE/EIA-0340(97).

individual consumers' storage tanks, including gasoline tanks of cars and home heating oil tanks.

Crude oil and petroleum products are stored in bulk in above-ground tanks, underground tanks and caverns, and offshore storage facilities. Above-ground tanks are the most common type of storage in the United States. Underground tanks are used primarily for storing gasoline and diesel fuel at service stations. Underground caverns are used around the

\section{Figure 6.5 Stocks of Major Petroleum Products by Storage Facility, December 31, 1997}

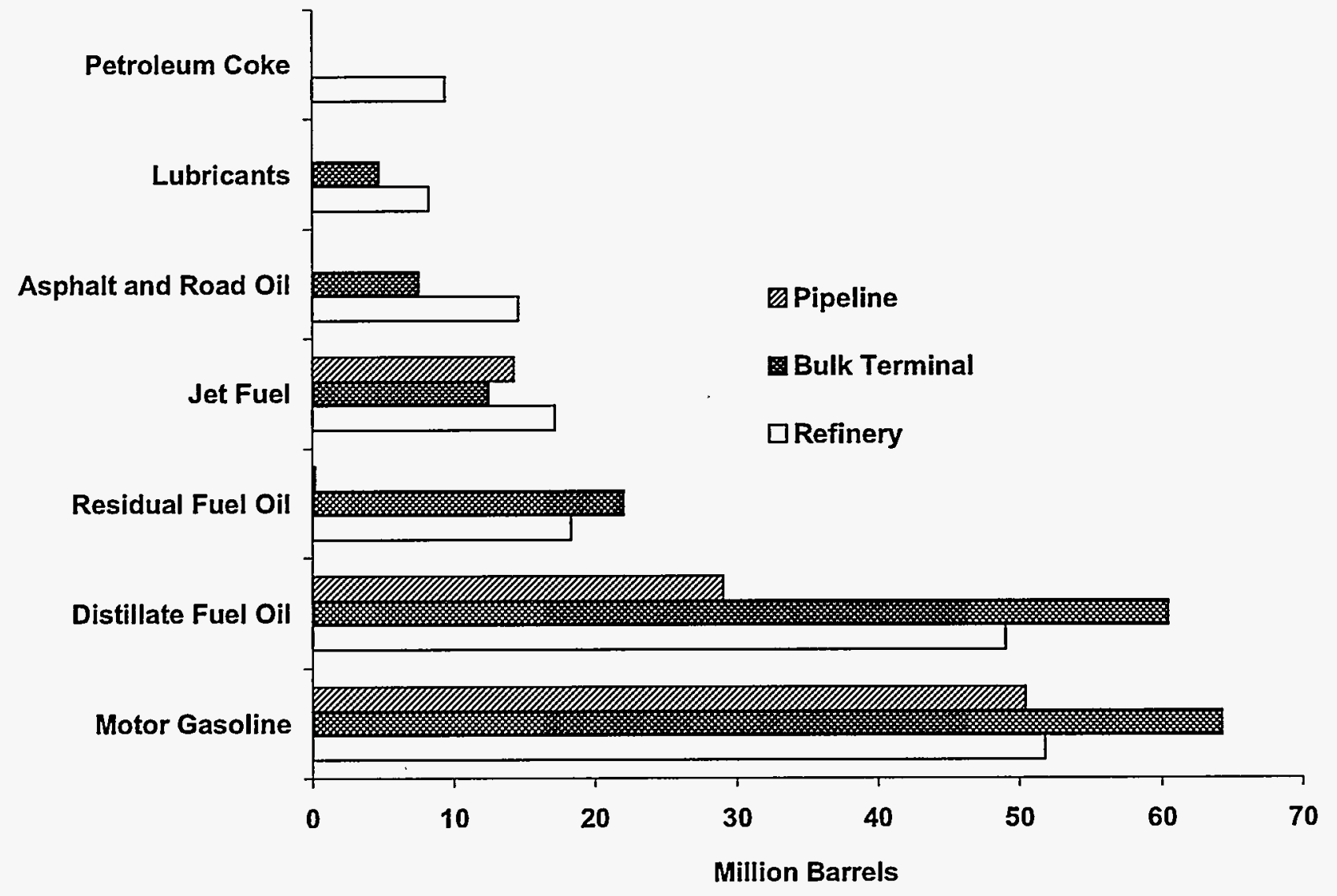

Source: Energy Information Administration, Petroleum Supply Annual 1997, DOE/ELA-0340(97). 
world to store both crude oil and products, but in the United States they are used primarily for crude oil and liquefied petroleum gases.

Except for their roofs, the above-ground tanks are of similar construction. Steel plates are bolted or welded together to form the cylindrical shell. Tank bottoms rest on a foundation of earth or concrete, and individual or groups of tanks are surrounded by a dike to contain oil in case of a spill. Tanks are generally painted on the outside with white or reflective paint to reduce heat absorption. Limiting corrosion and rust is a primary maintenance problem. Cathode systems, which use weak electric currents to prevent corrosion, are sometimes built into tanks.

Petroleum and petroleum products are volatile substances that evaporate easily. When stored, the liquid and the vapor expand and contract with changes in temperature. Tank roofs are designed to accommodate changes in the vapor pressure inside the tank and to minimize the loss of vapor during filling and emptying. Several types of roofs have been developed for different products and storage situations. A "fixed" or "cone" roof, attached to the tank shell around its edges, expands or contracts when vapor pressure changes. These tanks are generally used to store crude oil and products with low vapor pressure such as kerosene, fuel oil, and diesel oil. Floating roofs, lying on top of the liquid inside the tank, help to prevent loss by evaporation. They also increase safety and reduce maintenance because potentially explosive and corrosive vapors cannot build up under the roof. A lifter roof fits tightly over the outside of the tank and raises up and down as vapor pressure changes. Products with high volatility, such as gasoline, are usually stored in floating roof or lifter roof tanks. Floating roof tanks are practical at sites where there is frequent filling and emptying because they reduce vapor loss during these operations.

Most underground storage tanks (UST's) are constructed of carbon steel. Fiberglass-reinforced plastic and corrosionprotected steel are also used. Environmental problems associated with leaking tank systems led to legislation in 1984 authorizing EPA regulation of UST's. In 1988, EPA issued technical standards and financial responsibility regulations aimed at preventing leaks and addressing cleanup costs. EPA regulations requiring that certain underground storage tanks be protected from corrosion, overflow, and use leak detection systems were phased in over a 10 year period that ended in December 1998.

Highly volatile petroleum products, such as propane and butane, are difficult to store under normal temperature and pressure condtions. Special refrigerated and pressurized tanks were developed in the 1920's and 1930's to store these products. Very thick oils may be stored in heated tanks.
Storage facilities need enough tank capacity to hold the maximum shipment they expect to receive; but because filling and emptying are continuous, tanks are, on average, used at only about one-half of their capacity. At the beginning of 1997, there were 842 million barrels of shell storage capacity-the maximum amount a tank could hold if all its storage space were usable-at refineries and gasoline blending plants in the United States. ${ }^{9}$ The practical measure of how much a tank can hold is its working storage capacity, or the tank's maximum capacity less empty space at the top required for safety and non-accessible space at the bottom. At the beginning of 1997, the United States had about 745 million barrels of working storage capacity at refineries and blending plants. ${ }^{10}$

Three types of underground caverns can be used to store oil: solution-mined salt caverns, conventionally mined rock caverns, and reused mines. In the United States, only solutionmined salt caverns are used to any extent. Salt caverns in Louisiana and Texas contain oil for the Strategic Petroleum Reserve while salt caverns in Texas, Mississippi, and Kansas are major storage sites for liquefied petroleum gases. Underground salt deposits are good storage containers for oil because the oil cannot permeate the salt structure. They are relatively easy to construct by solution-mining (leaching), wherein a well is drilled and fresh water is pumped into the deposit to dissolve the salt. When the cavern is the preferred size and shape, it is filled with oil pumped in through the well. The oil displaces the brine pushing it up and out of the cavern. In most salt caverns used for working storage, oil is removed by pumping in saturated brine to displace the oil.

Offshore storage systems have been developed to collect oil where pipelines are not readily available to ship it to onshore storage sites. Some systems in use today are converted tankers (floating storage) and steel or concrete tanks on the sea floor. The major technological problem in developing offshore storage is maintaining stability in ocean currents.

\section{Stocks}

The petroleum distribution system consists of three sectors designated primary, secondary, and tertiary. The primary sector includes the shipment and storage of crude oil, refining, and the delivery and storage of products at local bulk terminals (wholesale marketing facilities having at least 50,000 barrels of storage capacity or receiving products by barge, tanker, or pipeline). The secondary sector includes bulk plants (marketing facilities having less than a 50,000-barrel capacity and receiving products by rail or truck only) and retail establishments. Final users comprise the tertiary sector.

Stocks of crude oil and petroleum products are volumes in storage at a particular time. Crude oil stocks held by private businesses in the primary sector fluctuated around $250 \mathrm{mil}-$

9 Energy Information Administration, Petroleum Supply Annual 1996, DOE/EIA-0340(96)/1, Table 44.

10 Energy Information Administration, Petroleum Supply Annual 1996, DOE/EIA-0340(96)/1, Table 43. 
Figure 6.6 U.S. Stocks of Crude Oil and Petroleum Products, End of Year 1949-1997

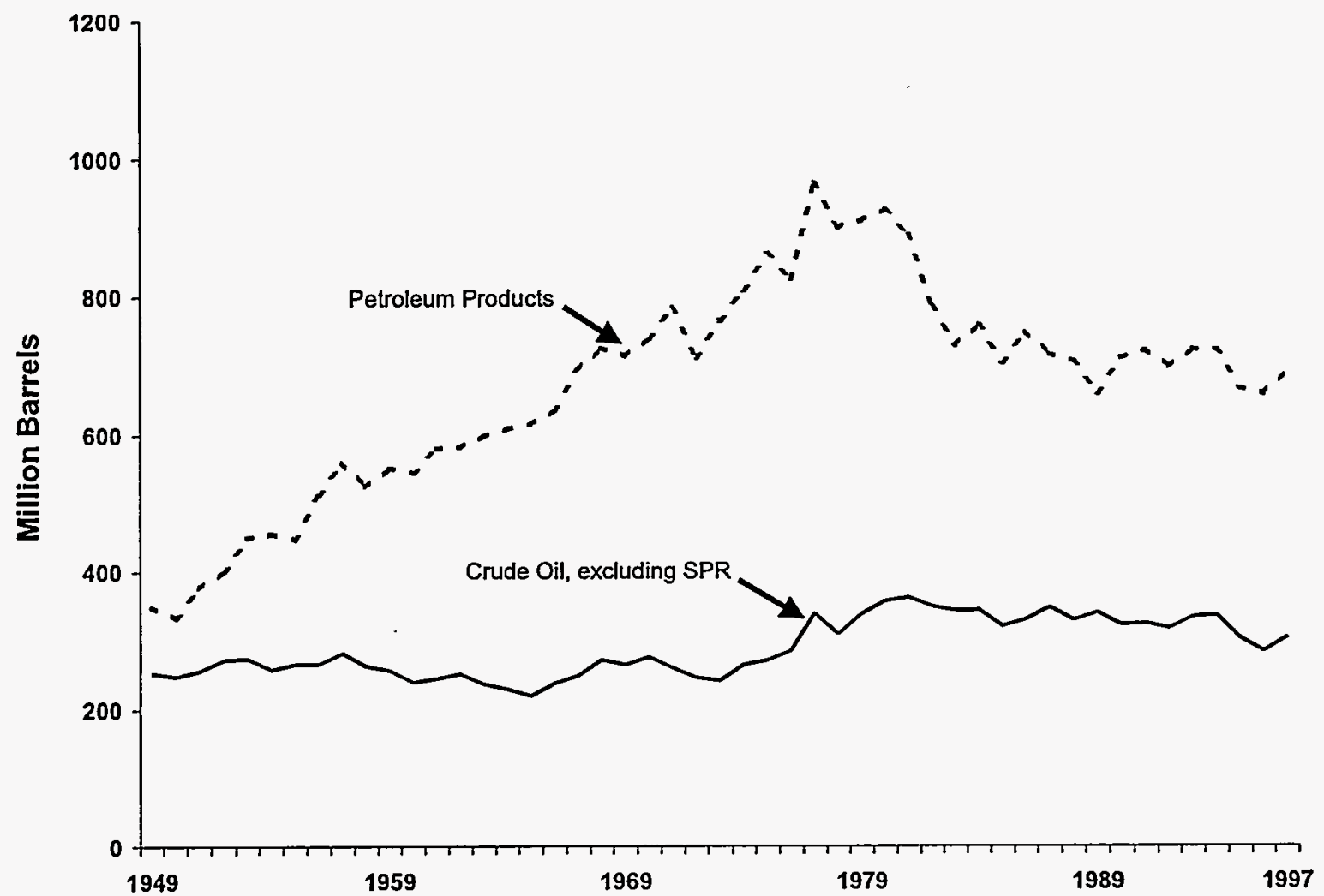

Source: 1949-1996: Energy Information Administration, Annual Energy Review 1996; 1997: Energy Information Administration, Petroletm Supply Annual 1997.

lion barrels from 1949 until 1976, when a buildup of inventories began (Figure 6.6). As of December 31, 1997, primary stocks of crude oil were 305 million barrels. Fluctuations in crude oil stocks can occur because of changes in the demand for refined products, in the expected availability of crude oil supplies, and in the cost of holding inventories. Refiners may keep crude oil stocks to protect themselves from having to shut down if an expected shipment fails to arrive. Stocks of crude oil held by private industry usually are maintained at or above the minimum operating inventory level, the minimum level needed to sustain operations of the distribution system. Below that level, operating problems begin to occur.

Stocks played an important role during the Persian Gulf crisis in 1990 and 1991. Prior to Iraq's invasion of Kuwait, petroleum stocks in the United States and in the rest of the world were higher than usual. These relatively high inventory levels cushioned the impact when the United Nations Security Council approved an embargo against oil exports from Iraq and Kuwait that reduced world oil supplies by an estimated 4.3 million barrels per day. During the crisis, U.S. stocks were drawn down more rapidly than usual, leaving crude oil stocks at the end of 1990 lower than they were at the end of other recent years.

To guard against the impact of a major, long-term shortage of crude oil and reduce concerns about supply interruptions, the
United States established the Strategic Petroleum Reserve (SPR) (see page 40). In 1977, the SPR fill rate began with imported crude oil. By 1994, the SPR had reached its maximum storage of 592 million barrels. ${ }^{11}$ As of the end of 1997 , the SPR contained 563 million barrels of crude oil. ${ }^{12}$

As demand grew following World War II, primary stocks of petroleum products increased. In 1980, they began to decline sharply, primarily reflecting a decrease in stocks of distillate fuel oil and motor gasoline. High carrying costs and volatile prices contributed to the gradual decline in product stock levels in the 1980's. Stocks of products also fluctuated from month to month due to seasonal demand. For example, refiners may increase their stocks of products prior to a seasonal demand peak.

It is difficult to measure stocks in the secondary sector because few data are collected from many retail outlets. The National Petroleum Council (NPC), however, estimated in their 1998 study, that inventories of products held at bulk plants were 22 million barrels and inventories at retail outlets were 44 million barrels. ${ }^{13}$

It is practically impossible to measure the amount of petroleum stocks held in the tertiary or end-use sector, although in the event of a supply disruption they could be

11 Energy Information Administration, 25th Anniversary of the 1973 Oil Embargo, DOE/ELA-0624, (August 1998), p. 9.

12 Energy Information Administration, Petroleum Supply Annual 1997, DOE/EIA-0340(97)/1, p. 7.

13 National Petroleum Council, Petroleum Storage and Transportation, Volume IV (Washington DC, 1998), p. 1-8. 
very important. Tertiary stocks do fluctuate, especially if a shortage or substantial price change is anticipated. For example, during the 1978 oil crisis, people waited in long lines to top off their automobile tanks, thus keeping their holdings of gasoline stocks high. In their 1998 study, the NPC estimated that there were 247 million barrels of petroleum products held in the tertiary sector, of which about 45 percent was diesel fuel and distillate fuel oil and about 25 percent was motor gasoline. ${ }^{14}$
In the future, as U.S. crude oil production declines, the transportation and storage system will need to adapt to the new sources and types of oil being delivered to U.S. refineries. Some changes which may occur are the addition of pipelines, changes in the use of existing pipelines, and enlargement of port facilities. Environmental concerns have already led to new regulations for storage facilities and tankers. Pipelines are also likely to feel the effects of changing environmental regulations that will require adjustments in the current distribution system.

For the most recent data on inter-regional movements of crude oil and petroleum products and storage volumes of petroleum products by type of storage facility, look for the current issue of the Petroleum Supply Monthly on the "Petroleum" page of EIA's website at http://www.eia.doe.gov/. Refinery receipts of crude oil by method of transportation are published every other year (i.e., 1996, 1998, etc.) in the Petroleum Supply Annual, Volume 1, also on the "Petroleum" page. 


\section{Imports and Exports}

Petroleum imports ${ }^{1}$ play a much larger role in U.S. foreign trade than petroleum exports, and their role is expected to expand as domestic crude oil supplies diminish. Net imports ${ }^{2}$ currently account for nearly 5 out of every 10 barrels of crude oil and petroleum products used in the United States (Figure 7.1 ) and could account for nearly 7 out of every 10 barrels by the year $2020 .^{3}$

As petroleum demand increases, U.S. petroleum refineries keep pace by processing domestic and imported crude oils to produce the desired product slate. Refineries respond to changing demand patterns and changing crude oil sources by adding or reducing capacity for a given process or altering utilization levels to adjust output. Or, based upon the nature and level of demand, refinery distillation and downstream capacity, and the quality, availability, and price of crude oil and other feedstocks, refiners and others may opt to import finished products. Refinery processing of crude oil to satisfy U.S. demand for gasoline and other light products inevitably produces other heavier products such as heavy gas oils and petroleum coke for which there is less domestic demand. To maximize return on investment, oil companies market these heavier products at home or abroad. Demand for these fuels is greater in other parts of the world and significant amounts are exported.

Historically, government policy has affected petroleum imports and exports. Both import regulations designed to support domestic prices and protect domestic producers, and export regulations designed to protect domestic supply availability have influenced U.S. petroleum trade.

As early as 1932, the Federal government imposed import fees on crude oil and refined products. ${ }^{4}$ The Mandatory Oil Import Program replaced voluntary import quotas in 1959. This program, which remained in effect until 1973, generally restricted imports to a percentage of domestic production. Price and allocation controls were suspended with deregulation of the oil industry in 1981. Currently, petroleum imports are subject to the tariffs specified in the Tariff schedules of the United States and collected by the U.S. Customs Service. However, the United States-Canada Free Trade Agreement of 1988 provided for the phaseout of duties on petroleum imports from Canada by 1993 . More than 15 percent ofU.S. petroleum imports in 1997 came from Canada.
Product export controls authorized under the Emergency Petroleum Allocation Act in 1973 were lifted in October 1981. Product exports increased substantially after the controls were lifted.

\section{Imports}

In the late 19th century, the U.S. oil industry supplied between 80 and 90 percent of the world's oil. In the early 1920 's, overseas exploration resulted in discovery of vast new fields in the Middle East. As low-cost oil from these new sources began to enter the world market, imports began to play a major role in U.S. petroleum supply. By 1948 , the United States was importing more petroleum than it exported. The United States has been a "net importer" of crude oil and petroleum products ever since.

By 1953, gross imports of crude oil and refined products averaged over 1 million barrels per day. Net imports (imports minus exports) amounted to over 600,000 barrels per day and accounted for approximately 8 percent of demand in the United States, already the world's largest oil consumer. Domestic producers were concerned that competition from foreign oil was lowering prices and forcing them to limit production. In 1955, Congress amended the 1953 Trade Expansion Act, giving the President virtually unlimited power to restrict imports if national security were threatened. Despite the establishment of voluntary import quotas in 1957, imports continued to increase. In 1959, mandatory quotas were imposed and remained in effect until $1973 .{ }^{5}$

Meanwhile, five key oil producing nations (Venezuela, Saudi Arabia, Iran, Iraq, and Kuwait) banded together in 1960 to form the Organization of Petroleum Exporting Countries (OPEC). Over the next decade eight other countries joined the cartel, which sought to protect the revenues and market shares of its members as oil demand grew worldwide.

Government wage and price controls instituted throughout the U.S. economy in 1971 to combat inflation stabilized domestic oil prices below rapidly escalating world prices. This encouraged the development of foreign oil sources and reduced domestic production. ${ }^{6}$ Imports nearly doubled between 1970 and 1973, rising to nearly 6.3 million barrels per day, with crude oil accounting for more than half. Net im-

1 The Energy Information Administration defines imports as the receipt of crude oil and pefroleum products into the 50 States and the District of Columbia from foreign countries, Puerto Rico, the Virgin Islands, and other U.S. possessions and territories.

2 Imports minus exports.

3 Energy Information Administration, Annual Energy Outlook 1999, DOE/ELA-0383(99) Table A11, p. 116.

4 The Intemal Revenue Act of 1932 placed import fees on crude oil and certain refined products to encourage domestic refining.

5 Congressional Quarterly, Energy Policy, 2nd ed. (Washington, DC: Congressional Quarterly, 1981), pp.30-31.

6 U.S. Department of Energy, United States Energy Policy, 1980-1988, DOE/S-0068 (October 1988), p. 4. 
Figure 7.1 Petroleum Flow, 1997

(Million Barrels per Day)

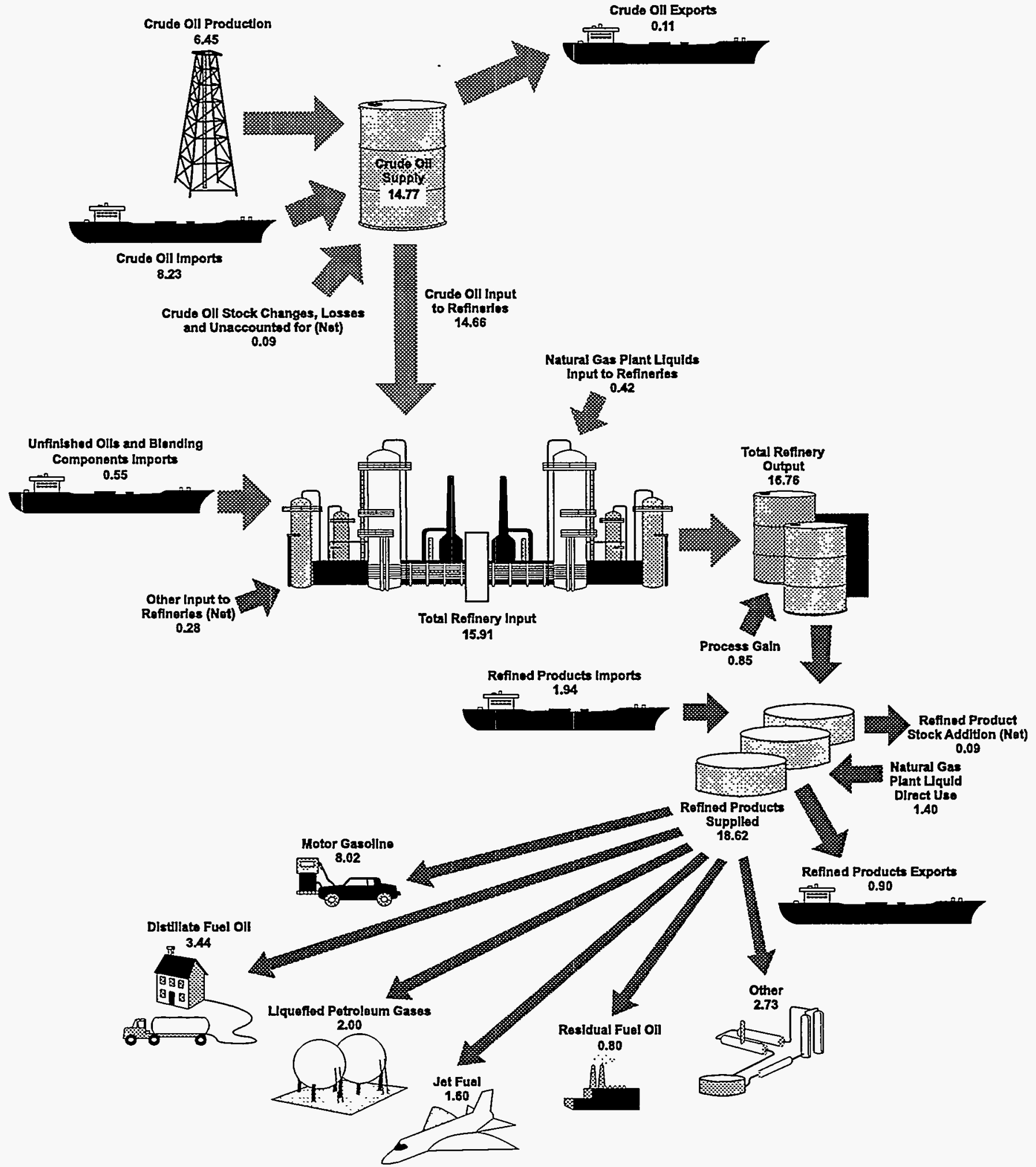

Source: Energy Information Administration, Petroleum Supply Annual 1997, DOE/EIA-0340(97)/1. 
ports averaged more than 6 million barrels per day. OPEC sources supplied almost 3 million barrels per day (net) of crude oil and products in 1973, or approximately 17 percent of total U.S. demand. The growth in imports was due largely to economic growth, rising personal income, and greater numbers of automobiles which stimulated demand for oil, just as domestic production, which had peaked at 9.6 million barrels per day in 1970, began to decline.

Dependence on OPEC supplies was becoming evident in other countries as well and led to the first major oil shock. Oil prices in a sellers' market doubled during 1973. Then, in response to U.S. support for Israel in the October 1973 Arab-Israeli war, Arab producers reduced production and implemented an oil embargo against the United States and other countries. By the spring of 1974, oil prices had climbed to four times their level at the beginning of the previous year. In response to these OPEC actions, the President and congress continued the price controls on U.S. crude oil and adopted a 21-cent-per-barrel crude oil import fee.

Despite rapidly rising prices and a wide range of U.S. efforts toward energy independence, U.S. reliance on foreign crude oil continued to grow through the 1970's. Imports peaked in 1977 at 8.8 million barrels per day; net imports averaged 8.6 million barrels per day, or the equivalent of 47 percent of domestic demand.

After the Iranian revolution in 1978 and 1979, foreign crude oil prices rose again, providing incentive for domestic exploration and development. Oil from Alaska's North Slope, which began moving through the Trans-Alaska Pipeline in 1977 , contributed a substantial share to domestic supplies. New supplies from non-OPEC sources in the Western Hemisphere displaced some OPEC oil. Conservation measures also began to have some effect. By 1983, gross imports of crude oil and petroleum products averaged less than 5.1 million barrels per day, 43 percent below their 1977 level. (Exports of Alaskan crude oil and certain refined products surged in the late 1970's and early 1980's, so net imports dropped even more dramatically.) Although OPEC members supplied 70 percent of U.S. petroleum imports in 1977, their share continued to shrink until 1985, when OPEC members supplied 36 percent (Figure 7.2).

In an attempt to regain market share and to recover lost power in the marketplace, OPEC members increased production, flooding the already over-supplied market. This sent oil prices plunging to between $\$ 9$ and $\$ 11$ per barrel by the summer of 1986. The price collapse had two major effects in the United states: (1) it boosted demand and (2) it forced domestic producers to curtail drilling. The result was an increase in imports, especially from OPEC suppliers. ${ }^{7}$ By 1997, total petroleum net imports had grown to 9.2 million barrels per day, accounting for 49 percent of U.S. demand, the highest import dependency level ever recorded.
- The Organization of Petroleum Exporting countries (OPEC) continued to increase in importance as a source of petroleum imports. By 1997, imports from OPEC members reached nearly 4.6 million barrels per day, the highest level since 1979 and about two and one-half times the 1985 level. Imports from Venezuela and Saudi Arabia accounted for most of the increase during this period.

Meanwhile, imported crude oil destined for the Strategic Petroleum Reserve (SPR), which began in 1977, peaked at 256,000 barrels per day in 1981 , before falling to only 12,000 barrels per day by 1994. After 1994, imported crude oil was not used to fill the SPR.

Crude oil accounted for about three-fourths of total petroleum imports during the late 1970's, before falling to about two-thirds by the early 1980's. However, crude oil imports again gained importance and grew to account for more than four-fifths of total petroleum imports by 1997 . Crude oil imports averaged 8.2 million barrels per day in 1997, with about 46 percent coming from $O P E C$ sources. Non-OPEC sources provided most of the crude oil imported from 1982 through 1985; however, some OPEC members, especially Saudi Arabia re-emerged as leading suppliers of crude oil to the United States during this period. Crude oil imports from Saudi Arabia grew steadily until their peak during the 1991 Persian Gulf War. Ten countries including both OPEC and nonOPEC sources (Kuwait, Saudi Arabia, Gabon, Nigeria, Venezuela, Angola, Canada, Colombia, Mexico, and Norway) accounted for nearly 9 out of every 10 barrels of crude oil imported into the United States in 1997 (Figure 7.3).

Since the mid-1980's, imports of refined products have declined, accounting for slightly more than one-third of total imports in 1985, to less than one-fifth of total imports by 1997. Most of the major petroleum product imports over this period have remained relatively consistent, except for residual fuel oil. Since the late 1950's, when residual accounted for around 90 percent of refined product imports, its share has dwindled, while the shares of other products such as motor gasoline, distillate fuel oil, liquefied petroleum gases, and unfinished oil have generally increased (Table 7.1).

Nearly 54 percent of all refined product imports in 1997 came from only three sources: Venezuela, Canada, and the Virgin Islands. Algeria and Saudi Arabia were among the other major suppliers. Moreover, the Virgin Islands was the leading source of finished motor gasoline, distillate fuel oil, and unfinished oils.

Most petroleum imports enter the United States through refiners, brokers, and bulk terminals in three major geographic areas. The Gulf Coast, a major refining center, was the point of entry for 56 percent of the crude oil imported in 1997 . The East Coast and the Midwest also received large amounts of crude oil -18 percent and 20 percent of the total, respectively. Mostrefined products (56 percent of the total) entered

7 U.S. Department of Energy, United States Energy Policy, DOE/S-0068, 1980-1988, pp. 8-9. 
Figure 7.2 U.S. Petroleum Imports by Source, 1980-1997

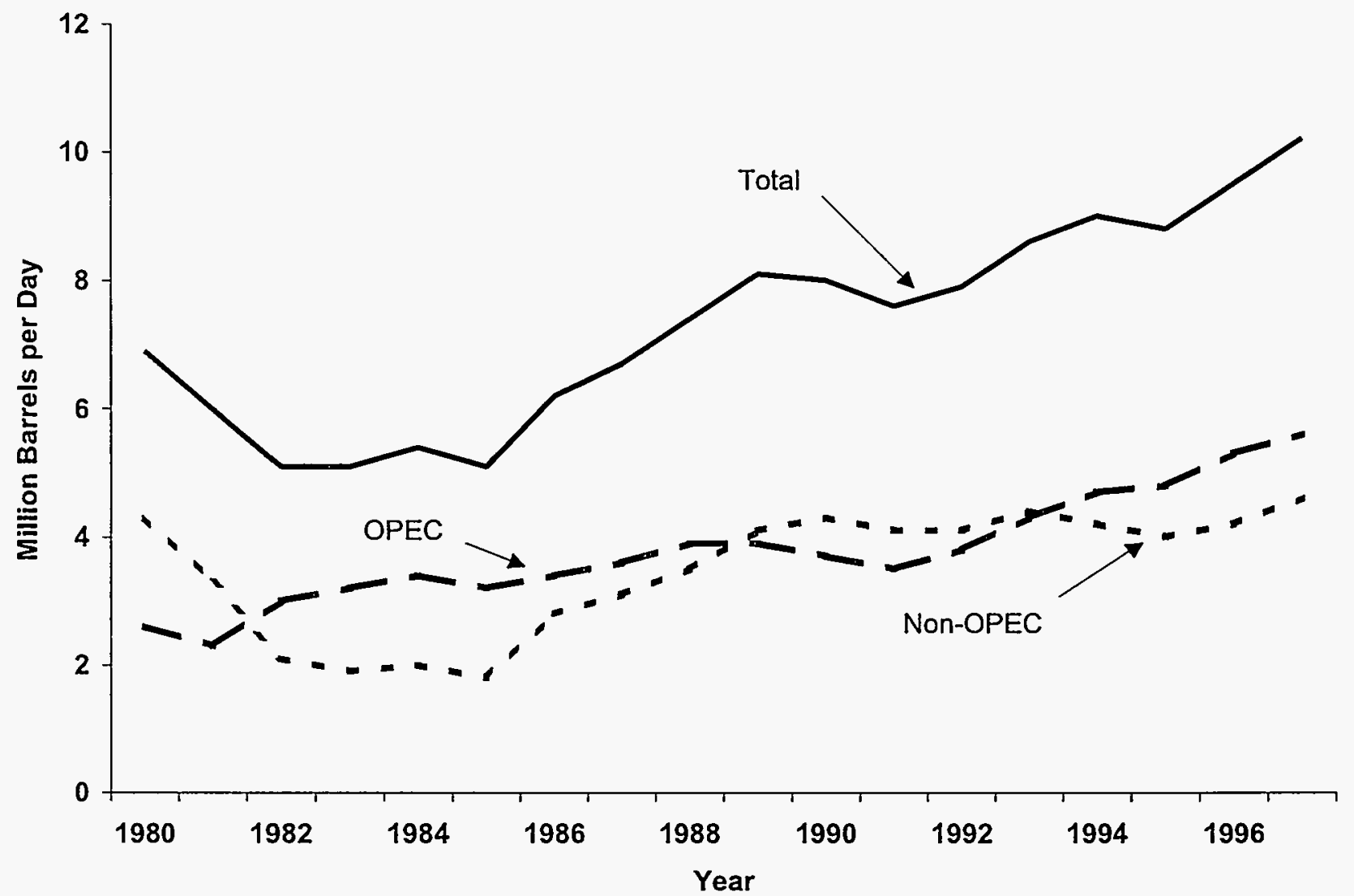

Source: Energy Information Administration, Petroleum Supply Annual 1997, DOE/EIA-0340(97)/1, and predecessor reports.

Table 7.1 Petroleum Product Imports by Type, Selected Years 1955-1997 (Thousand Barrels per Day)

\begin{tabular}{|c|c|c|c|c|c|c|c|c|}
\hline Year & $\begin{array}{c}\text { Distillate } \\
\text { Fuel Oil }\end{array}$ & $\begin{array}{c}\text { Jet } \\
\text { Fuel }\end{array}$ & $\begin{array}{c}\text { Liquefied } \\
\text { Petroleum } \\
\text { Gases }\end{array}$ & $\begin{array}{c}\text { Motor } \\
\text { Gasoline }\end{array}$ & $\begin{array}{c}\text { Residual } \\
\text { Fuel Oil }\end{array}$ & $\begin{array}{c}\text { Unfinished } \\
\text { Oils }\end{array}$ & $\begin{array}{c}\text { Other } \\
\text { Products }\end{array}$ & $\begin{array}{c}\text { Total } \\
\text { Products }\end{array}$ \\
\hline 1955 & 12 & NA & 0 & 13 & 417 & 15 & 9 & 466 \\
\hline 1960 & 35 & 34 & 4 & 27 & 637 & 45 & 17 & 799 \\
\hline 1965 & 36 & 81 & 21 & 28 & 946 & 92 & 27 & 1,229 \\
\hline 1970 & 147 & 144 & 52 & 67 & 1,528 & 108 & 49 & 2,095 \\
\hline 1975 & 155 & 133 & 112 & 184 & 1,223 & 36 & 109 & 1,951 \\
\hline 1980 & 142 & 80 & 216 & 140 & 939 & 55 & 76 & 1,646 \\
\hline 1985 & 200 & 39 & 187 & 381 & 510 & 318 & 232 & 1,866 \\
\hline 1990 & 278 & 108 & 188 & 342 & 504 & 413 & 291 & 2,123 \\
\hline 1995 & 193 & 106 & 146 & 265 & 187 & 349 & 359 & 1,605 \\
\hline 1997 & 228 & 91 & 169 & 309 & 194 & 353 & 591 & 1,936 \\
\hline
\end{tabular}

${ }^{1}$ Includes aviation gasoline, motor gasoline blending components, aviation gasoline blending components, kerosene, petrochemcial feedstocks, special naphthas, lubricants, wax, asphalt, petroleum coke, pentanes plus, and miscellaneous products.

NA $=$ Not Available.

Note: Totals may not equal sum of components due to independent rounding.

Source: 1955-1995: Energy Information Administration, Annual Energy Review 1997, DOE/EIA-0384(97), Table 5.3; 1997: Energy Information Administration, Petroleum Supply Annual 1997, DOE/EIA-0340(97)/1, Table 20. 


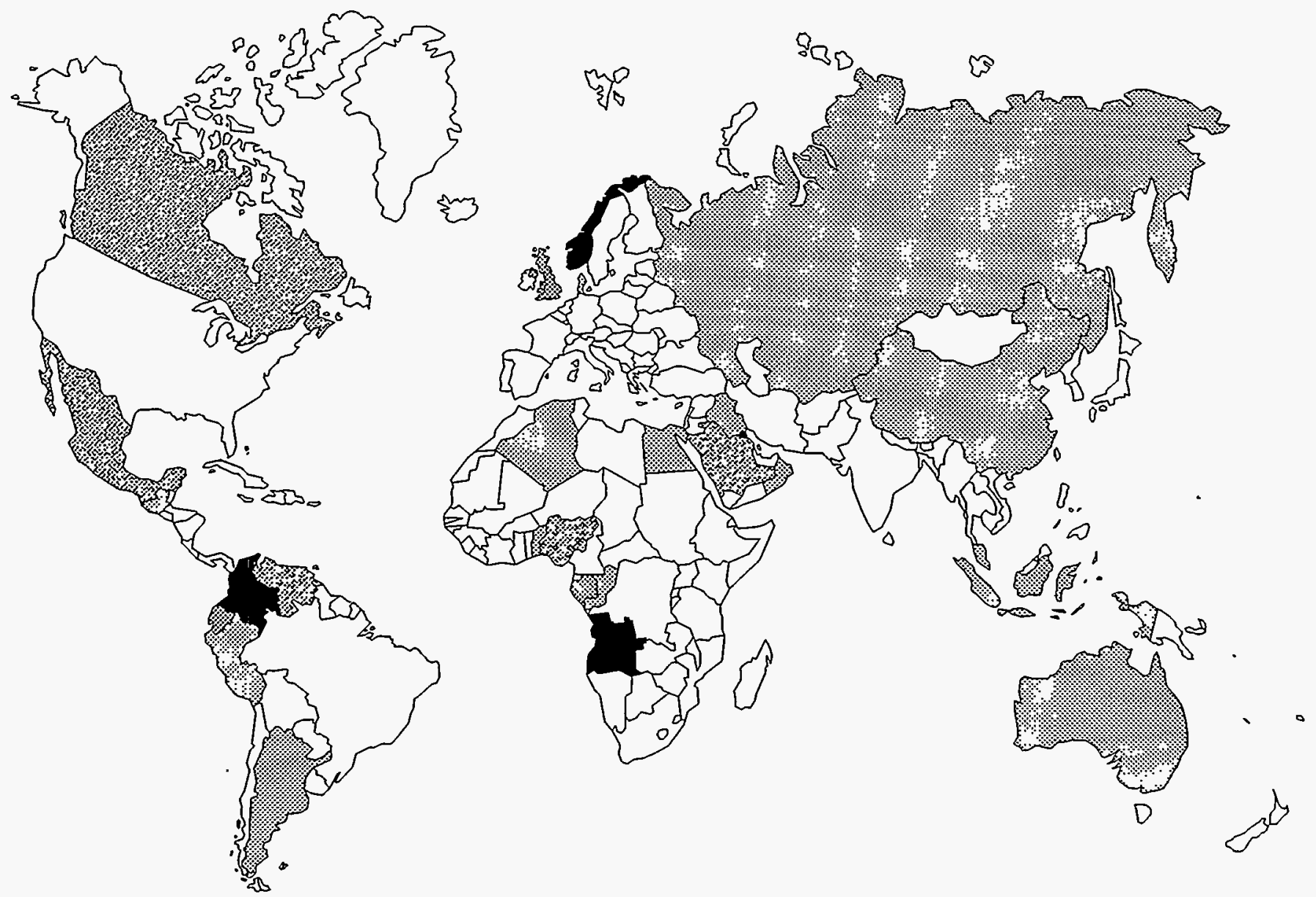

Thousand Barrels per Day

1 to 99
100 to 249
250 to 499
500 and above

Source: Energy Information Administration, Petroleum Supply Annual 1997, DOE/ELA-0340(97)/1.

the country along the East Coast. The Gulf Coast was the other major receiving area for product imports (33 percent).

Companies that operate refineries are the leading importers of crude oil and petroleum products in the United States. Large integrated oil companies import crude oil almost exclusively for processing in their U.S. refineries. Large independent oil companies are also heavy importers of crude oil, but import products as well. Smaller refiners tend to import either refined products exclusively or a mix that is predominantly crude oil. Bulk-terminal operators, brokers, and consumers bring in nearly one-half of the major petroleum products imported. Despite unused domestic refining capacity, traders and consumers can sometimes obtain products more economically from foreign sources, if nearby refineries lack the facilities, location, or distribution system necessary to serve them at competitive prices. Product imports have established a niche in many high-demand U.S. markets that may expand in the future, especially in meeting sudden, short-term demand surges (such as seasonal changes in gasoline and heating oil demand).

\section{Exports}

The United States exported 1.0 million barrels per day of crude oil and petroleum products ${ }^{8}$ in 1997, matching the record level set in 1993. More than half of all U.S. petroleum exports are destined for five countries-Japan, Canada, 
Mexico, the Republic of Korea, and Spain (Figure7.4). Petroleum coke is the leading petroleum product exported to Japan, accounting for 57 percent of total U.S. petroleum exports to that country in 1997. Special naphtha was another major petroleum product exported to Japan. Residual fuel oil, petroleum coke, crude oil, and jet fuel were the major U.S. petroleum exports to Canada in 1997. Of these exports, residual fuel oil and petroleum coke accounted for similar 13 percent shares. Motor gasoline accounted for 43 percent of the petroleum exported to Mexico in 1997. Liquefied petroleum gases and distillate fuel oil accounted for most of the remainder. Petroleum coke accounts for virtually all of the petroleum exports to Spain. Crude oil accounted for 67 percent of the U.S. petroleum exports to the Republic of Korea in 1997.

Figure 7.4 U.S. Petroleum Exports by Destination, 1997

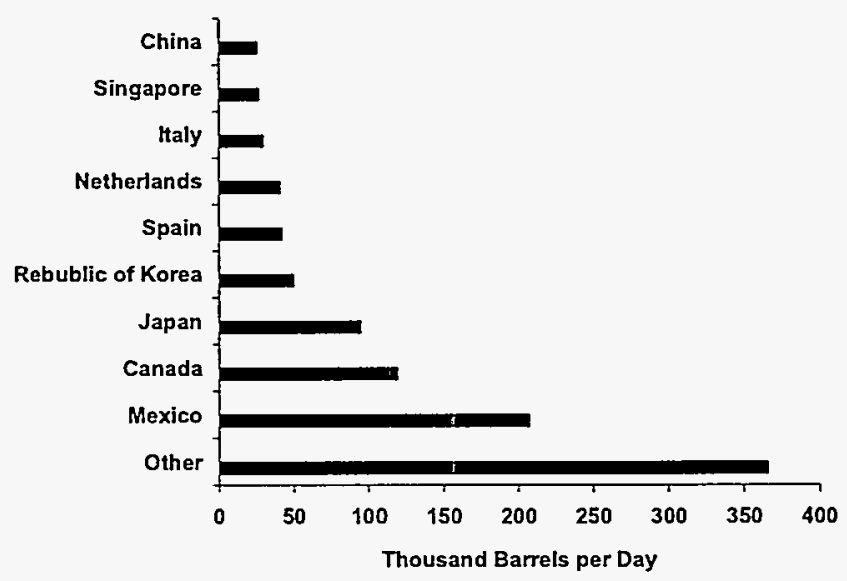

Source: Energy Information Administration, Petroleum Supply Annual 1997, DOE/EIA-0340(97)/1.

In the past, various laws restricted petroleum exports. The Export Administration Acts of 1969, 1979, and 1985 authorized the President, through the Secretary of Commerce, to restrict exports when they would be to the Nation's detriment. Export licensing is carried out through the Commerce Department's Office of Export Administration. In 1973, the Emergency Petroleum Allocation Act authorized export controls that included a system of quotas administered through the Commerce Department's export licensing procedures. These quotas were in effect until allocation controls were lifted on October 1981. While petroleum product exports were heavily restricted between 1973 and 1981, they have been largely unrestricted since that time. Crude oil exports are presently limited to oil delivered from fields under State waters of Alaska's Cook Inlet, certain domestically produced crude oil destined for Canada, and shipments to U.S. territories, and California crude oil to Pacific Rim countries?.
Petroleum exports increased steadily from 1975 through 1982, with the export of Alaskan North Slope crude oil to the Virgin Islands and Puerto Rico accounting for much of the increase beginning in 1977. After dipping somewhat in the mid- 80 's, petroleum exports have remained near or above 1.0 million barrels per day since 1991 .

Crude oil exports peaked in 1980 at 287,000 barrels per day. By 1997, crude oil exports averaged 108,000 barrels per day, accounting for about 11 percent of total petroleum exports. The Republic of Korea received the largest share of total U.S. crude oil exports, or more than 1 out of ever 3 barrels of crude oil exported from the United States during 1997.

Product exports increased substantially after allocation controls governing the export of petroleum products were lifted in October 1981: product exports for 1981 averaged 367,000 barrels per day, and by 1982 they reached 579,000 barrels per day, more than double the 1980 level of 258,000 barrels per day. Product exports have averaged more than 600,000 barrels per day since 1986 , and reached 896,000 barrels per day in 1997, when they accounted for more than 89 percent of total petroleum exports.

Heavy products such as residual fuel oil and petroleum coke are co-products of motor gasoline. When U.S. refineries process crude oil to meet U.S. motor gasoline demand, they necessarily produce heavier fuels as well, often in quantities greater than required for the domestic market. Foreign demand absorbs the excess.

Petroleum coke is the leading petroleum export product, accounting for about 30 percent of petroleum exports in 1997 (Figure 7.5). Japan, Spain, and Italy are the leading destinations for U.S. exports of this commodity.

Distillate fuel oil is the second most exported product, accounting for 15 percent of total U.S. petroleum product exports. Exports of distillate fuel oil increased dramatically following the lifting of export controls, to a high of 274,000 barrels per day by 1993 . However, by 1997, exports of distillate fuel had dropped to 152,000 barrels per day. Mexico and Singapore, the Netherlands, and Canada were the main destinations.

The third most exported product in 1997 was motor gasoline, accounting for nearly 14 percent of total U.S. petroleum product exports. Mexico was the leading destination for motor gasoline with a nearly 66 percent share of total exports.

While foreign demand is the primary factor determining export levels for the heavierpetroleum products, there are other economic incentives for exporting petroleum products. For example, shipping costs may be lower for exports than for domestic transfers because many international water shipments are shorter than domestic transfers. Also, because

9 On December 6, 1991, the U.S. Department of Commerce approved a license to export 25,000 barrels per day of California heavy crude oil (less than 20 degrees API gravity) to Pacific Rim countries for one year. 
Figure 7.5 Exports of Crude Oil and Petroleum Products, 1997

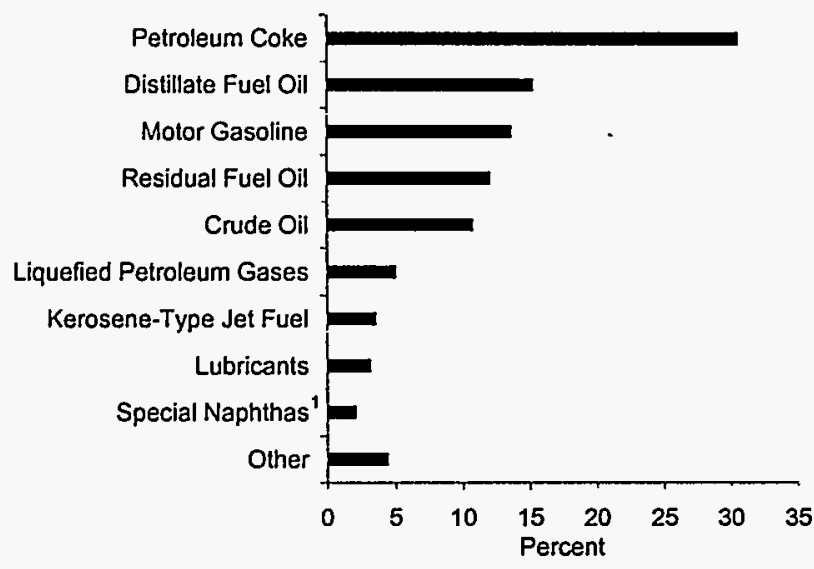

'Includes pentanes plus, other hydrocarbons/oxygenates, motor gasoline blending components, naphtha-type jet fuel, kerosene, waxes, asphalt and road oil, and miscellaneous products.

Note: Components do not add to 100 percent due to independent rounding.

Source: Energy Information Administration, Petroleum Supply Annual 1997. DOE/EIA-0340(97)/1, Table 28.

many U.S. ports cannot accommodate large supertankers, domestic shipments are often unable to realize the same economies of scale as international shipments. In addition, U.S. law requires that commodities transported from one U.S. port to another be carried in ships built in the United
States or U.S. flag vessels manned by U.S. seamen, making these shipments more costly than international shipments. Opposing these incentives to export are foreign restrictions such as tariffs in the European Economic Community and Japan that render many U.S. refined products too costly for the market in those countries.

Prices and other market conditions also influence exports. For example, higher gasoline prices in Europe drew unusually large volumes of motor gasoline exports from the United States as price increases triggered by the Persian Gulf crisis coincided with the end of the 1990 summer driving season to curb domestic demand.

Future exports of petroleum from the United States will depend on economic conditions worldwide and the restrictions placed on trade both in this country and abroad. The industrialized countries will continue to be the major oil consumers over the next 20 years. Petroleum use will increase at the fastest rate in the developing countries, however. The United States currently exports refined petroleum products to several of the developing countries, with Mexico being the largest destination. In 1997, Mexico received nearly 207 barrels per day of petroleum products from the United States. The United States can be expected to continue exporting petroleum products, especially the heavy products used by these and other countries, because of less emphasis on the heavy products in this country. Transportation costs, other economic factors, and political events will determine these future export volumes and destinations.

For the most recent data on U.S. imports and exports of crude oil and petroleum products, look for the current issues of the Weekly Petroleum Status Report and the Petroleum Supply Monthly on the "Petroleum" page of ELA's website at http://www.eia.doe.gov/. Historical series are available in the Monthly Energy Review and the Annual Energy Review on the "Historical" page of our website. In addition, company-level imports data are available monthly, also on the "Petroleum" page. 



\section{Petroleum Marketing}

Petroleum companies are a mix of large integrated companies known often as "major oil companies" and smaller "independents." Integrated oil companies own and operate establishments in many facets of the industry, from exploration through marketing. The independent companies, although greater in number than the majors, own a smaller share of the industry. These companies usually specialize in one particular activity of the oil industry, such as production or marketing (as independent drilling or exploration contractors or independent service station operators).

The petroleum market can be thought of as two separate but interdependent markets for crude oil and products in which the majors, independents, and a host of traders and marketers cooperate in transferring ownership from producers to consumers. Crude oil ownership is transferred from producers to refiners by transactions in the crude oil market. Products refined from crude oil are sold to final consumers in the petroleum products market, where price movements are similar, but not entirely parallel, to those in the crude oil market. In recent years, the trading of petroleum "futures" has added a new dimension to both markets.

\section{Crude Oil}

\section{Crude Oil Transactions}

Refiners are the ultimate consumers of crude oil. Resellers act as middlemen, purchasing oil from producers and then selling it to refiners. Oil brokers arrange trades, bringing buyers and sellers together for a brokering fee. Refiners, resellers, or brokers may import crude oil from foreign sources.

Integrated companies, which operate refineries and produce their own crude oil, can simply transfer oil from one company department to another. Even integrated companies, however, often buy and sell crude oil outside the company.

Exchanges are very common methods of transferring crude oil ownership. For example, if Company A produces crude oil from fields that are located far from its refinery, that company may exchange its crude oil for that of Company B whose fields are located closer to Company A's refinery. If Company B operates a refinery near Company A's production field, then the exchange is mutually beneficial, as both save the cost of transporting their oil. Companies may also exchange crude oils of different grades or quality to obtain the kind of oil suitable to their refineries' needs. Payments are made to cover location or quality differentials.
Crude oil purchases and exchanges can be accomplished by long-term contracts or through spot market acquisitions. Long-term contracts specify the volumes to be delivered and fix the price for a period of time. Since the middle 1980's, more and more crude oil has been bought and sold on the spot market, where single cargoes of oil are purchased for more immediate delivery. Buyers and sellers agree on a price at the same time of sale, which is much closer to the actual delivery date. Therefore, the "spot" price is usually a better indicator of current market conditions than long-term contract prices.

\section{Crude Oil Prices}

The crude oil market was fairly stable from the late 1940's until 1973. Since then, crude oil prices have experienced changes, reacting to market forces, U.S. government regulations, and world political events (Figure 8.1). In 1973, the Arab oil embargo presented the world with its first major energy crisis. Crude oil prices rose sharply as Arab producers cut world supply. The Iranian revolution in 1978 gave the world oil market its second major shock. In late 1978, an oil field strike in Iran halted production there. The lack of exports cut world supplies and the price of oil again increased greatly. When the Iran/Iraq war started in 1980 , prices increased again. Ten years later, Iraq's invasion of Kuwait began another sudden escalation of prices.

In response to crude oil shortages caused by the energy crises of the 1970's, mandatory and voluntary conservation programs were initiated to reduce the demand for petroleum products. These measures included reducing highway speed limits, lowering temperatures in commercial buildings and residences, increasing fuel economy of automobiles, and restricting gasoline purchases to certain days and/or minimum amounts. In the mid-1970's, the Government instituted a program which managed the distribution of limited crude oil and product supplies among refiners. The general effect of these regulations was to keep the market from responding normally to supply and demand pressures. Price controls placed on domestically produced crude oil and refined products in 1971, as part of the Federal Government's inflation-fighting wage and price control program, held down the price of domestic crude oil while world oil prices were rising. When the Government lifted these controls in 1981, domestic oil producers were allowed to raise their prices for the first time since the early 1970's, and domestic crude oil prices became more closely aligned with foreign crude oil prices. In 1981 , the average cost of domestic crude oil at the wellhead was $\$ 31.77$ per barrel, about $\$ 10$ more per barrel than the previous year. ${ }^{1}$ 


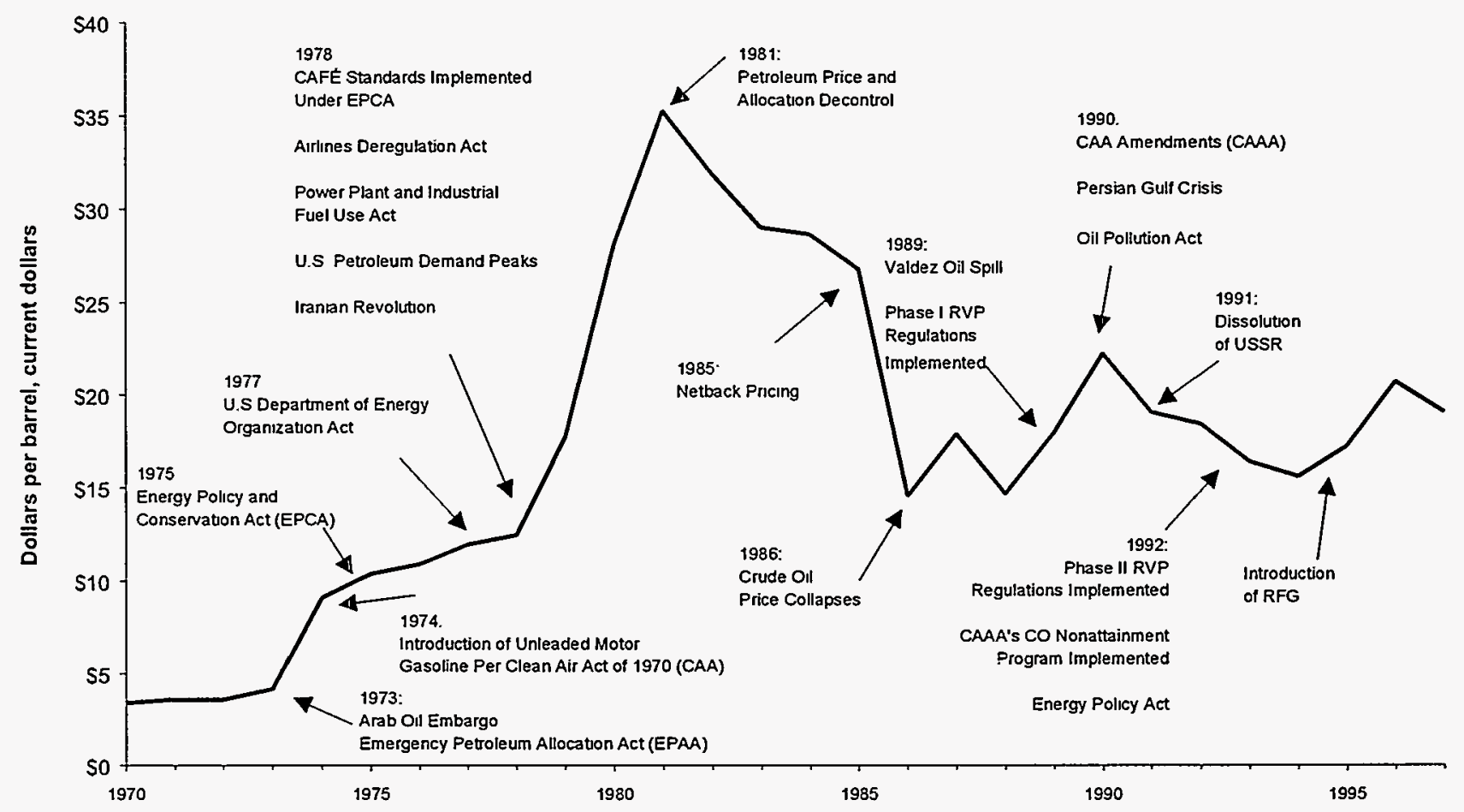

Source: Energy Information Administration, Annual Energy Review 1997, DOE/EIA-0384(97), Table 5.19.

The Organization of Petroleum Exporting Countries (OPEC) (see Glossary) has influenced world oil prices since it was organized in 1960 . Originally created to negotiate production and pricing matters with the major oil companies that at the time had large controlling interests in those countries' supplies, OPEC now tries to keep prices at its target level by setting an upper production limit on its members. OPEC has the potential to influence oil prices worldwide because its miembers possess such a great portion of the world's oil supply. Although OPEC lost some of its market share in the late 1970's and early 1980's, its members still account for nearly 43 percent $^{2}$ of the world's production of crude oil and hold about 67 percent $^{3}$ of the world's estimated remaining reserves.

In 1982, world crude oil prices began a downward trend as demand slackened. Increasing production by non-OPEC countries, such as Egypt, Mexico, Norway, and the United Kingdom, combined with the effects of conservation investment in earlier periods created an oversupply of oil on the world market. When a resurgence in OPEC production began in 1986, crude oil prices plummeted. In the years following the price collapse, prices fluctuated as world oil demand increased slightly, and OPEC continued to struggle to keep production within its agreed-upon limits.
On August 2, 1990, Iraq invaded Kuwait, causing crude oil and product prices to rise suddenly and sharply for the third time in 17 years. After the United Nations approved an embargo on all crude oil and products originating from either country, uncertainty about future supplies caused the rapid price escalation. Between the end of July and August 24, 1990 , the world price of crude oil climbed from about $\$ 16$ per barrel to more than $\$ 28$ per barrel. The price escalated further in September, reaching about $\$ 36$ perbarrel. ${ }^{4}$ By the end of November, however, as production from other countries offset the loss of Iraqi and Kuwati oil in world markets, and fears of a worldwide shortage subsided, petroleum prices stabilized. Refiners paid an average of $\$ 21.76$ per barrel for imported crude oil in 1990, 20 percent higher than in 1989, but still well below the average of $\$ 37.05$ in $1981 .^{5}$

\section{Petroleum Futures}

Unlike contract and spot markets, the futures market is a paper market where contracts for crude oil and some petroleum products are bought and sold. Successful futures trading began in 1978 when futures contracts for No. 2 heating oil were first offered on the New York Mercantile Exchange (NYMEX). NYMEX remains the leader in energy futures

2 Energy Information Administration, Monthly Energy Review, DOE/EIA-0035(99/02) February 1999, Tables 10.1a and 10.1b.

3 Energy Information Administration, Annual Energy Review, 1997, DOE/EIA-0384(97), Table 11.3.

4 Energy Information Administration, Weekly Petroleum Status Report, DOE/EIA-0208(91-11) March 1, 1991.

5 Energy Information Administration, Annual Energy Review ,1997, DOE-EIA-0384(97), Table 5.19. 
trading. Petroleum futures contracts are also traded at the International Petroleum Exchange in London and at the Singapore International Monetary Exchange (SIMEX).

Futures trading of crude oil on NYMEX began in 1983. It is the most actively traded petroleum commodity in the futures market. Other products traded include unleaded gasoline, which NYMEX began trading in 1984, and propane, which has been traded since 1987. Leaded gasoline was traded on NYMEX from 1981 to 1986. In 1986 and 1987, futures market activity was expanded with the introduction of options contracts for crude oil and heating oil. In 1989, options contracts for gasoline were added. Reformulated gasoline, required by EPA in large urban non-complying ozone areas, has been added to the list of commodities traded on NYMEX.

A futures contract is an agreement between a seller to deliver and a buyer to accept a commodity on a designated date in the future for a specified price. The contract defines a standard quantity and quality of the product and the point of delivery. On the NYMEX, for example, all crude oil contracts specify 1,000 barrels of West Texas Intermediate ${ }^{6}$ crude oil to be delivered at Cushing, Oklahoma, as a standard. The price is settled by negotiation when the contract is sold.

One contract can be traded many times before the actual delivery date, each time at a new price. Therefore, the futures price should approach the market price as it gets closer to the delivery date. Because the futures market is largely used as a means of assuring price and availability of future oil supplies, many more contracts are traded than oil is actually delivered.

Futures trades at the exchange are executed by brokers who are members of the exchange, and act for the actual purchaser/seller. In addition to providing a means for trading parties to interact, the exchange also guarantees to settle contracts if one of the parties defaults. Part of the reason it can make this guarantee is that the broker must put up a percentage of the contract's value (called a margin), which is forfeited if the trader does not fulfill his contract obligations. The required margin increases if the value of the futures contract decreases, thus increasing the cost of defaulting and lowering the risk that a trader will default to avoid a loss. NYMEX conducts petroleum futures trading under regulation by the Commodity Futures Trading Commission.

An options contract gives the trader the right to buy or sell a futures contract at a later date for a specified price. It is not, however, an obligation to buy or sell. The right to buy is known as a "call" option and the right to sell as a "put" option. The option may or may not be exercised depending on how futures prices change. If an option is not exercised, the buyer loses a premium paid to the seller.
The futures market succeeds because of contract liquidity and price uncertainty, which has dominated the oil market since the early 1970's. Some traders use the futures market for speculating on price changes. More often, however, the futures market is used by producers and consumers to hedge against uncertainty in price or supply. A hedge is designed to protect a trader against losses when the price changes to his disadvantage. It can be accomplished because a hedger makes counterbalancing (opposite) transactions in the futures market and the cash market (where physical goods are traded).

Although a significant number of traders in petroleum futures contracts are professional market traders with no interest in oil itself, the number of oil industry participants is large and growing. Refiners, producers, and marketers are most likely to use the futures market for hedging. For example, an oil producer can establish the sales price for oil that will be produced later, by selling a futures contract. Then, if a drop in market price causes the value of the oil held for later production to decline, the loss will be borne by the holder of the futures contract. Likewise, a refiner may want to fix the price that must be paid for crude oil that is needed in the future, by buying a futures contract. An increase in the price of crude oil means a larger amount must be paid to purchase the oil in the cash market, but the refiner would be able to profit on the resale of the futures contract. Of course, if the price of crude oil decreases, the refiner will not be able to maximize profits because of obligations on futures contracts. Many companies, however, are willing to forego some of the potential profits in order to decrease their risks of loss. Hedging also makes it easier for companies to plan and budget for the future since they do not have to worry as much about price changes.

Options contracts can also be used to protect against adverse price changes. However, because the purchaser is not required to complete the transaction, options traders do not have to forego all profits during favorable price changes. If, for example, a refiner has an option to buy a crude oil contract and the price of oil declines, the refiner will buy the lower priced oil on the cash market but is not obligated to pay the higher price to the seller of the options contract. Options trading does have a cost, of course, namely the premium which must be paid in order to trade.

The volume of oil being traded as futures is very large and has grown rapidly in the last few years - nearly 24.8 million crude oil futures contracts and 5.8 million crude oil options were traded on NYMEX in 1997. The up-to-date price information which is readily available from the exchange can influence price negotiations on the spot market and on long-term contracts. Nowadays, the prices for crude oil agreed on in the cash markets are usually tied to the price of a few "reference" crude oils like West Texas Intermediate, and the prices for these references are basically determined by traders in the futures market. Likewise, petroleum product prices, even for those products not traded in the futures mar-

6 West Texas Intermediate (WTI) is a high-quality light, low sulfur crude oil that is used as the U.S. benchmark crude oil; i.e., it serves as the standard by which other U.S. cnide oils are compared. 
ket, are often linked to product prices or even crude oil prices in the futures market.

\section{Petroleum Products}

\section{Product Marketing}

Unlike crude oil, which is mostly consumed by only one kind of final user, refined petroleum products are ultimately sold to a variety of users in the transportation, residential, industrial, commercial, and electric utility sectors of the economy. Products may be sold directly to end users by the refiner, but most often the consumer buys from a retailer. Resellers, often defined as wholesale dealers, are the middlemen. They buy from refiners and sell to other resellers or to retail outlets. Many resellers are also retailers.

Wholesale marketers of petroleum products usually own and/or operate bulk plants or terminals where large quantities of products are stored and then distributed in smaller lots. The trucks which transport products from plants to the retailers are often owned and operated by the bulk plant. Bulk plants may be owned and operated by a major oil company, owned and operated by independent "jobbers," or owned by a major company but operated by independents. Company-operated bulk plants receive and distribute products supplied by the company and are operated by employees of the company. Independent operators of company-owned plants are usually "commission distributors" who sell prod- ucts on commission. They are committed to selling the company brand at the company's set price. Independent jobbers who own, or lease, and operate their own bulk plants, can be classified as "branded" or "unbranded" depending on whether they buy from one company and sell under its brand name or buy from many companies or independent refiners.

Many independent jobbers also participate in retailing activities by owning, or leasing, and operating service stations. They supply the stations from their bulk plant facilities. Some trucks are independently owned, i.e., not company owned or owned by bulk plants. Their owner/operators act as wholesalers (in cases where trucks supply gasoline to service stations) or as retailers (in cases where trucks deliver heating oil to end users). Some independent truck operators work for distributors on a commission basis.

Service stations, which first began to appear around 1910, remain the predominant retail establishments for marketing petroleum products. Before service stations, gasoline was sold in large cans mainly at hardware, grocery, and other general stores. In the 1920 's, as automobile ownership increased, the number of service stations rose rapidly. Many stations closed during World War II, but after the war the number increased again until the 1970 's. In the 1970's and 1980 's, the number of service stations in the United States declined dramatically, largely due to the closing of stations which were only marginally profitable. In some areas, one large station has replaced several smaller ones.

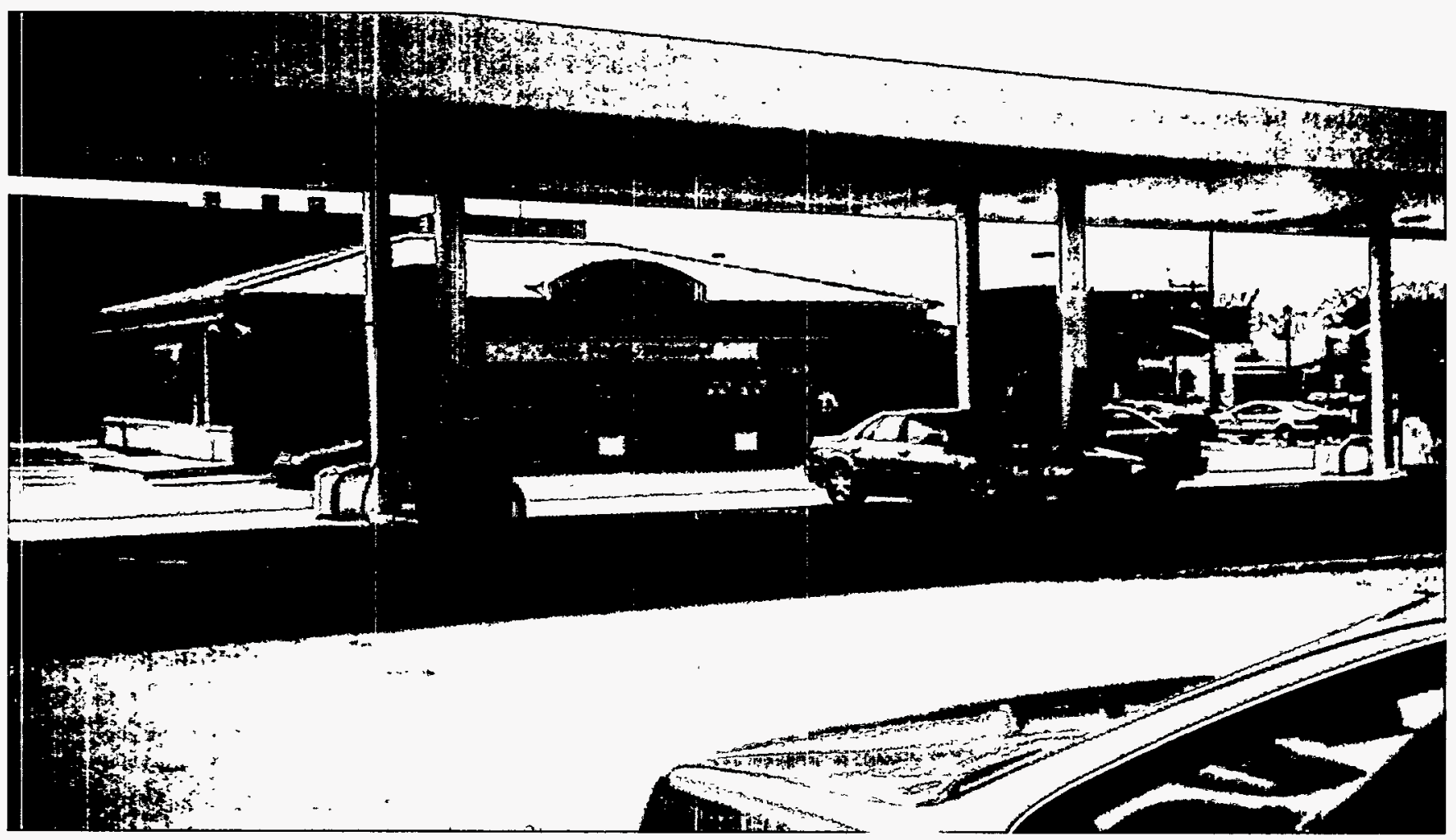

Today's modern service station provides added services including such things as mini-markets, car washes, and fast food franchises. 
Most service station outlets today are not company stations, i.e., owned or leased by a major oil company and operated by employees of the oil company. In 1997, companies marketed about one-fifth of the gasoline they manufactured through company outlets. ${ }^{7}$ The remainder was marketed through resellers or directly to end users. Most stations are operated by independent dealers. Dealers may own or lease their stations, in many cases leasing them from their supplier ( a major company or bulk terminal operator). Dealers are usually franchisees of a major company, selling only the company brand, but free to set their own prices. Companies supply products at wholesale to their dealers and often provide equipment as well. There are a few service stations which are completely independent, dealing with more than one supplier to obtain products at the lowest cost and setting the sales price independently.

History has shown that demand for gasoline is somewhat inelastic, i.e., a large change in price does not bring a proportional change in demand, and that price is not always the most important factor in a consumer's decision to buy from a particular dealer. These realizations have prompted marketers to engage in strategies for creating demand and increasing their market share. Over the years, service stations have expanded their product lines by adding more automotive services such as mechanical repair services, tire and battery sales, and car washes. Non-auto products such as convenience foods also have been offered for sale at many service stations. Games and give-aways have been used at various times to attract new and repeat business. Major companies began issuing credit cards to encourage loyalty to their brand. The introduction of self-service in the 1970's proved to be a very successful marketing technique. Self-service was designed to reduce the service station's costs and to increase the speed of customer service. According to National Petroleum News, approximately 90 percent of gasoline sales are now self-service.

There has been a recent resurgence of attention to marketing strategies. Faster pumps and more convenient payment systems, for example, are being installed to increase the speed of service. Attention is also being paid to upgrading the appearance of service stations to a more modern look, with some companies offering incentives to their dealers to remodel or rebuild. The number of convenience stores marketing gasoline in addition to other goods is also on the rise.

In many areas of the United States, marketers are installing payment systems using the latest electronic technology. Many service stations now accept debit cards in addition to credit cards. Debit cards are the cards used in automatic teller machines. When used at a service station, the amount of the gasoline purchase is deducted from a customer's checking account. By associating itself with a whole electronic network, a station can greatly increase its pool of potential customers. Other systems allow cards or cash to be inserted into the pump for payment.

\section{Product Prices}

Petroleum products are sold at different levels in the distribution chain. Class of trade prices (spot, rack, dealer tank wagon (DTW), and retail) provide information on where in the distribution chain prices change, and who benefits from the change (see Figure 8.2). Rack prices are prices paid for product sold from within the refinery or terminal loading racks. Only limited distribution and storage costs are included in this price. DTW price represents the prices paid by retailers for gasoline. Thus, the difference between retail

Figure 8.2 Simplified Gasoline Market Structure

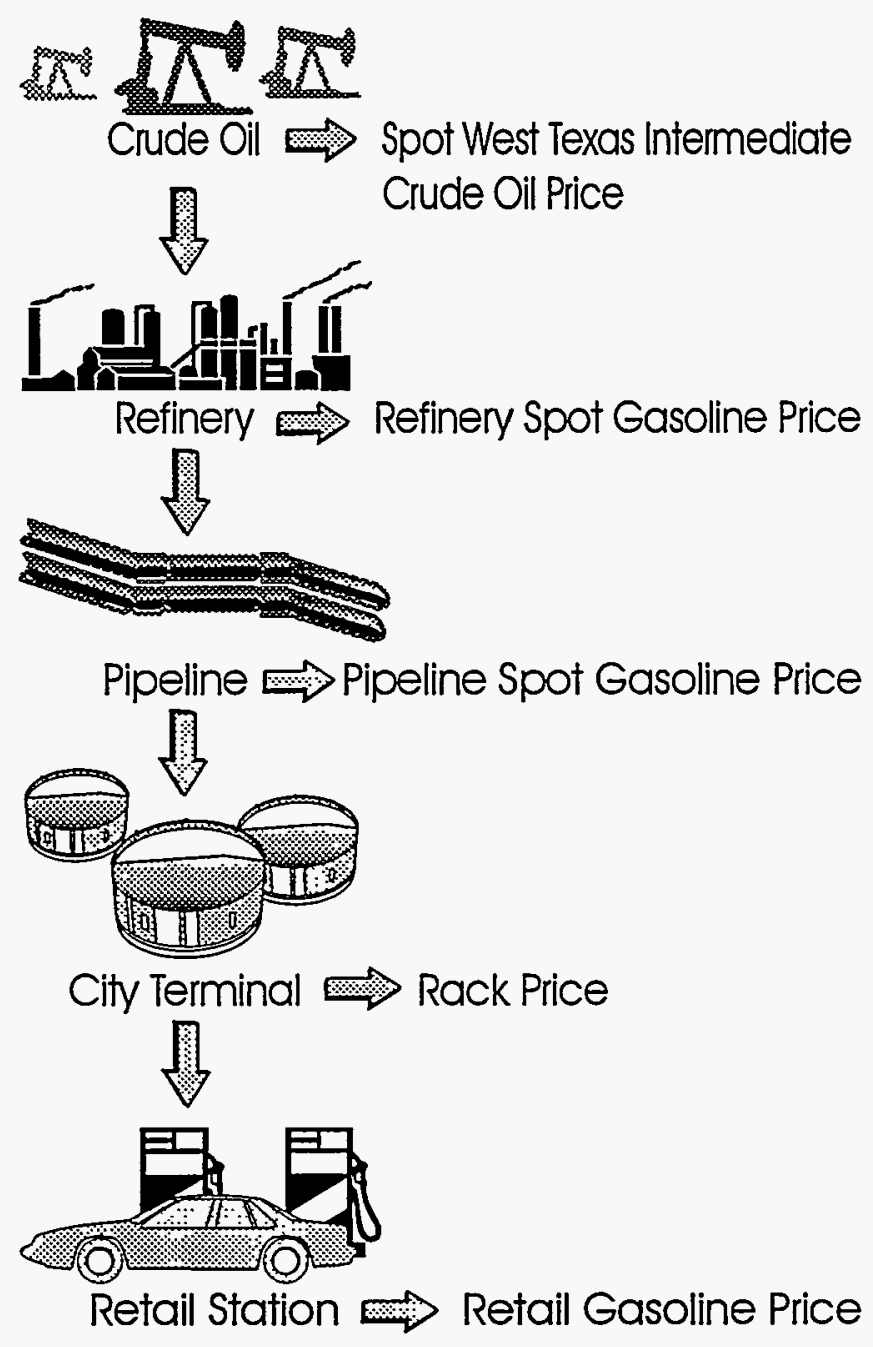

Source: "What Drives Gasoline Prices?," Energy Information Administration, Petroleum Marketing Monthly, DOE/EIA-0380 (June 1995), p. xiv.

price (excluding taxes) and DTW price is the money retailers have available to cover the cost of their operations and return on investment. The difference between rack price and crude oil cost represents the dollars refiners have to cover production costs and some storage and distribution costs. DTW

7 Energy Information Administration, Petroleum Marketing Annual, 1997, DOE/EIA-0487(97), Table 7. 
price includes additional marketing, distribution and storage costs beyond those covered in the rack price.

Class of trade prices include:

Spot Price - Represents a price agreed to by a wholesale buyer (e.g. distributor) and seller (e.g., refiner) for a single cargo of product. It can vary significantly day to day.

Rack Price - Refers to the wholesale price charged by wholesalers at their refineries or company terminals to open dealers or distributors. Rack prices are usually determined on a daily basis and are influenced by competitors' prices as well as by spot and futures market prices. Rack prices cover refining costs, including the cost of feedstocks and some storage costs.

DTW (Dealer Tank Wagon) Price - Is that charged by distributors and refiners to their retailers. These prices include transportation costs to the dealers' stations and other business costs (promotions, dealer incentives, etc.) beyond the basic rack price. DTW prices are established by considering competitors' prices and spot, futures, and rack prices.
Retail Price - Is the price paid by the consumer at the gasoline station. It includes the DTW price paid by the retail station for fuel, additional station operation costs, dealer margins and taxes.

Taxes are also a component of petroleum products prices. Excise taxes, for example those levied on motor fuels, account for a large fraction of the price. Many consumers are surprised at the size of the tax component of retail gasoline prices. As Figure 8.3 shows, taxes add almost 40 cents to the cost of each gallon of gasoline. In 1997, Federal excise tax for gasoline accounted for 18.3 cents while State taxes, including local sales taxes, averaged close to 22.0 cents. $^{8}$ State taxes vary from 7.5 cents in Georgia to 36 cents in Connecticut. Many times regional price differences are the result of taxes. Some retailers post the cost of taxes on their pumps, to inform the public about the importance of taxes in the prices they're paying.

Like taxes, manufacturing and marketing costs, which include the retailers' profit, also tend to change very slowly. In 1997, manufacturing and marketing costs accounted for 34.7 cents per gallon of regular gasoline at retail, while crude oil costs were 45.3 cents per gallon. Figure 8.4 shows crude oil and gasoline prices over the past 25 years. By far the most

\section{Figure 8.3 Components of Retail Regular Gasoline Prices, 1997}

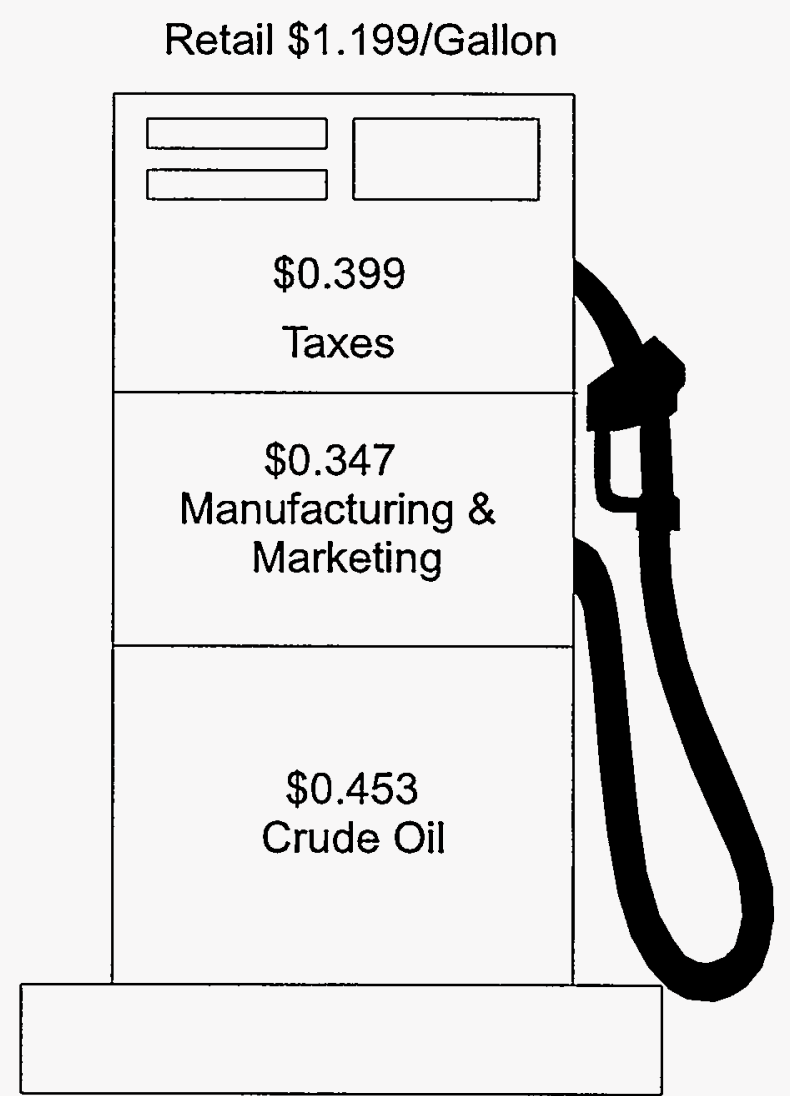

Source: Energy Information Administration, Petroleum Marketing Annual 1997, DOE/EIA-0384(97), Tables 1 and 31, and Annual Energy Review, 1997, DOE/ELA-0384(97), Table 5.22.

8 Energy Information Administration, Petroleum Marketing Annual 1997, DOE/ELA-0487(97), Table EN1. 
variable component of gasoline prices is the price of crude oil. But crude oil price changes take time to move through the distribution chain as shown in Figure 8.2. Generally, a change in the price of crude oil takes approximately 8 or 9 weeks for the customer to see the full effect of that change on motor gasoline prices.

The cost of crude oil is a major determinant of the price of refined products, but the price of products also reflects the demand for them. One influence on the demand for products is the availability of substitutes. In some sectors, like the transportation sector, it is difficult to switch quickly from one fuel to another without costly and irreversible equipment changes, but other sectors (primarily industry and electric utilities) can switch relatively quickly and easily. For example, equipment at large manufacturing plants often can use either residual fuel oil or natural gas. Often coal and natural gas can be easily substituted for residual fuel oil at electric generating plants. For some petroleum products demand is more sensitive to price than for other products, such as gasoline.

Figure 8.4 Prices of Crude Oil and Retail Regular Motor Gasoline, 1970-1997

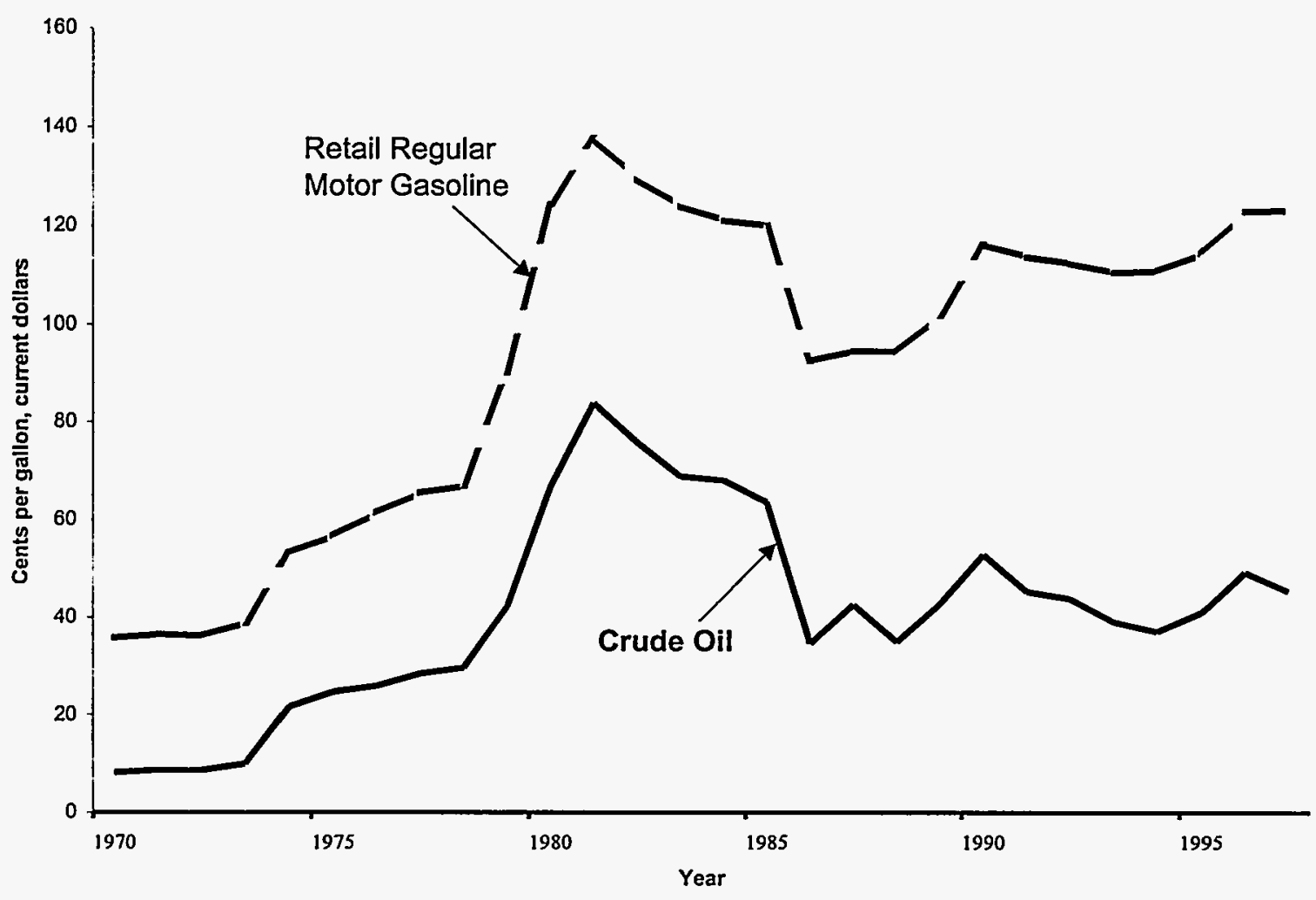

Source: Energy Information Administration, Annual Energy Review 1997, DOE/EIA-0384(97), Tables 5.19 and 5.22.

For the most recent data on crude oil and petroleum product prices, look for the current issues of the Weekly Petroleum Status Report and the Petroleum Marketing Monthly on the "Petroleum" page of ELA's website at http://www.eia.doe.gov/. In addition, historical series are available in the Monthly Energy Review and the Annual Energy Review on the "Historical" page of our website. 



\section{Appendix A: \\ District Descriptions and Maps}

The following are the Refining Districts which make up the Petroleum Administration for Defense (PAD) Districts.

\section{PAD District I}

East Coast: District of Columbia and the States of Maine, New Hampshire, Vermont, Massachusetts, Rhode Island, Connecticut, New Jersey, Delaware, Maryland, Virginia, North Carolina, South Carolina, Georgia, Florida, and the following counties of the State of New York: Cayuga, Tompkins, Chemung, and all counties east and north thereof. Also the following counties in the State of Pennsylvania: Bradford, Sullivan, Columbia, Montour, Northumberland, Dauphin, York, and all counties east thereof.

Appalachian No. 1: The State of West Virginia and those parts of the States of Pennsylvania and New York not included in the East Coast District.

\section{Sub-PAD District I}

New England: The States of Connecticut, Maine, Massachusetts, New Hampshire, Rhode Island and Vermont.

Central Atlantic: The District of Columbia and the States of Delaware, Maryland, New Jersey, New York, and Pennsylvania.

Lower Atlantic: The States of Florida, Georgia, North Carolina, South Carolina, Virginia and West Virginia.

\section{PAD District II}

Indiana-Illinois-Kentucky: The States of Indiana, Illinois, Kentucky, Tennessee, Michigan, and Ohio.

Minnesota-Wisconsin-North and South Dakota: The States of Minnesota, Wisconsin, North Dakota, and South Dakota.
Oklahoma-Kansas-Missouri: The States of Oklahoma, Kansas, Missouri, Nebraska, and Iowa.

\section{PAD District III}

Texas InIand: The State of Texas except the Texas Gulf Coast District.

Texas Gulf Coast: The following counties of the State of Texas: Newton, Orange, Jefferson, Jasper, Tyler, Hardin, Liberty, Chambers, Polk, San Jacinto, Montgomery, Harris, Galveston, Waller, Fort Bend, Brazoria, Wharton, Matagorda, Jackson, Victoria, Calhoun, Refugio, Aransas, San Patricio, Nueces, Kleberg, Kenedy, Willacy, and Cameron.

Louisiana Gulf Coast: The following parishes of the State of Louisiana: Vernon, Rapides, Avoyelles, Pointe Coupee, West Feliciana, East Feliciana, Saint Helena, Tangipahoa, Washington, and all parishes south thereof. Also the following counties of the State of Mississippi: Pearl River, Stone, George, Hancock, Harrison, and Jackson. Also the following counties of the State of Alabama: Mobile and Baldwin.

North Louisiana-Arkansas: The State of Arkansas and those parts of the States of Louisiana, Mississippi, and Alabama not included in the Louisiana Gulf Coast District.

New Mexico: The State of New Mexico.

\section{PAD District IV}

Rocky Mountain: The States of Montana, Idaho, Wyoming, Utah, and Colorado.

\section{PAD District V}

West Coast: The States of Washington, Oregon, California, Nevada, Arizona, Alaska, and Hawaii. 

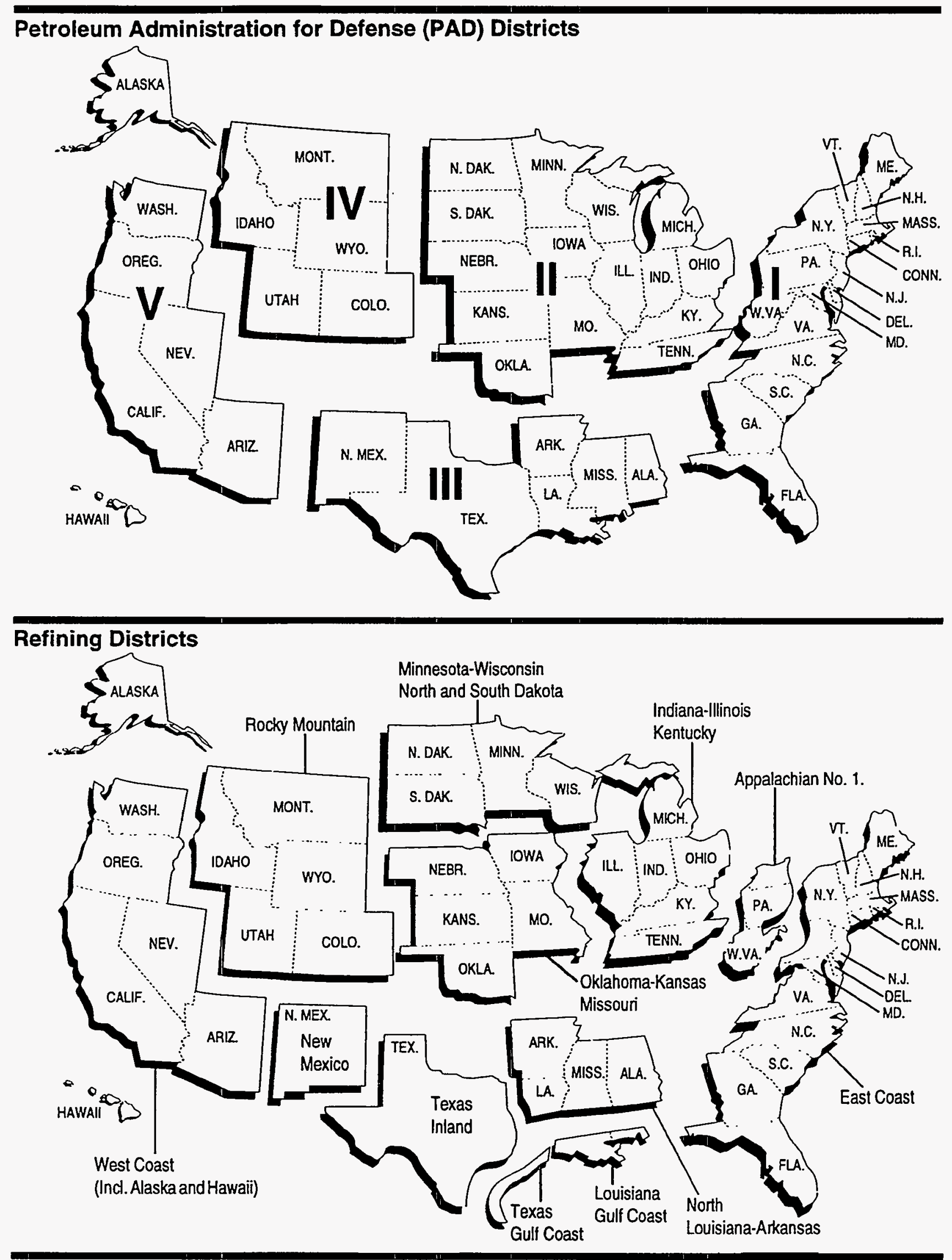


\section{Appendix B: Refinery Processes and Facilities}

Note: This Appendix is based on information contained in U.S. Petroleum Refining, Volume II, published by the National Petroleum Council, (Washington, DC, 1993) Appendix $\mathrm{H}$.

\section{Physical Separation Processes}

Atmospheric distillation is the first phase of refinery processing and generally follows a preparation process to remove salts, water, and soluble metals. Crude oil vaporizes when it is heated within the distillation column. As the boiling points of different products (hydrocarbons) are reached, the vapors condense and are collected in "stream" or "fractions." Those with the lowest boiling points, the "light" fractions such as fuel gas, light naphtha, and straight-run gasoline, vaporize at the top of the distillation column. These products are used as reformer feedstocks, gasoline blendstocks, and petrochemical feedstocks, or used directly (e.g., solvents and liquefied petroleum gases). Fractions in the intermediate boiling ranges, such as gas oil, heavy naphtha, and distillates, are used to produce kerosene, diesel fuel, distillate fuel oil, jet fuel, blending stocks, and catalytic cracker feedstocks. Atmospheric "bottoms" have the highest boiling range and remain after other fractions have been collected. They are used to produce heavy fuel oil, vacuum distillation feedstock, and asphalt.

At atmospheric pressure, "heavy bottoms" decompose into elemental carbon, coke, and hydrogen before they boil and vaporize. Vacuum distillation reduces pressure, which lowers the boiling point, allowing further vaporization to occur with charring or "coking." Vacuum distillation produces gas oil to feed downstream processes and heavier oils for lubricant and asphalt production. Vacuum bottoms are processed in coking units and converted to gasoline components, petroleum coke, and refinery gases or used as fuel.

Two other physical separation processes are mainly used to make lubricating oils: solvent extraction, in which a solvent removes one component and leaves behind a less soluble one; and crystallization, in which cooling allows a component with a high melting point to solidify and separate from the remaining liquid.

\section{Breakdown Processes}

Thermal cracking uses heat and pressure to "crack" or break down heavy oils and the residuum left from distillation to increase the yield of lighter products (such as gasoline components and light fuel oils) and to make coke. Coking, a form of thermal cracking, uses heat and low pressure to break down heavy crides and residual oils into fuel gas, gasoline blending stocks, distillates and coke. Viscosity Breaking, or visbreaking, a milder form of thermal cracking, raises the yield of fuel oil, lowers the viscosity of heavy fuel oil, and produces small amounts of gasoline blendstocks and gas oil.

Catalytic cracking employs a catalyst to convert vaporized oil from distillation and other units to high octane gasoline and other lighter distillates. It produces higher gasoline yields than thermal cracking and the gasoline produced has higher octane ratings than gasoline produced using distillation or thermal cracking. Catalytic cracking units operate at high temperature near atmospheric pressure. As the reaction takes place, the catalyst is progressively deactivated as carbon (coke) forms, but can be regenerated between cycles by burning off the coke. In continuous catalytic cracking, the catalyst cycles between the reactor and regenerating kiln. In fluid catalytic cracking, the fine powder catalyst behaves as fluid when vaporized oil bubbles through the particles and circulates continuously between reaction and regeneration zones.

Hydrocracking uses hydrogen and a catalyst to reduce heavy gas oils to gasoline, jet fuel, and diesel fuels. Operating temperatures are lower, and pressures higher, than in catalytic cracking. Hydrocracking is more effective than catalytic cracking in converting previously cracked gas oils to lighter products, but it is more expensive.

\section{Change Processes}

Catalytic reforming and isomerization are primarily used in making high octane unleaded gasoline to upgrade hydrocarbon streams whose molecules are the right size but the wrong configuration. Catalytic reforming upgrades low octane naphthas to produce high octane gasoline blending stocks. It also produces high yields of aromatic hydrocarbons used for petrochemical feedstocks, and generates hydrogen required for many refinery processes. Isomerization was developed to produce isobutane from normal butane, for use in the alkylation process. Isomerization uses platinum catalysts to 
convert low octane normal pentanes to high octane isopentane for unleaded motor gasoline.

\section{Buildup Processes}

Alkylation and polymerization join small, highly volatile, low octane molecules to form large, less volatile, higher octane molecules. Alkylation is basically the reverse of cracking; it combines small molecule hydrocarbons from catalytic cracking to form high octane compounds in the gasoline range for use in high octane unleaded motor gasoline and aviation gasoline.

The polymerization process links short chain molecules together. Although polymer gasolines are somewhat lower in octane and yields are lower than can be obtained through the alkylation process, capital and operating costs are lower for polymerization than for alkylation. As a result, polymerization recovered importance following the Environmental Protection Agency's (EPA) restriction of the lead content in gasoline. The process is also important in the petrochemical industry.

\section{Supporting Operation and Facilities}

- The refinery gas plant extracts alkylation feed and heavier components from refinery by product gases.

- Hydrodesulfurization is a catalytic process to remove impurities from liquid petroleum fractions, especially when their presence would harm the process catalyst. It reduces sulfur emissions, improves product yields, and upgrades petroleum fractions into finished products. Hydrogen required for this process and for other refinery processes such as hydrocracking and isomerization may be produced in a hydrogen production unit. Either steam reforming of hydrocarbons such as methane or partial oxidation of heavier hydrocarbons may be used to produce the hydrogen required.

- Chemical treating removes such impurities as carbon dioxide, oxidants, and various corrosion compounds from processing systems.

- Stabilization processes allow controlled distillation to remove enough light hydrocarbons that the remaining product has the desired volatility. Solvent treating, dewaxing, and hydrofinishing change heavy gas oils produced by vacuum distillation into high quality lubricants. In solvent treating, solvents and "lube" (lubricant) stocks flow against one another in a tower to remove impurities. Dewaxing uses a solvent to dilute lube stocks in order to remove the wax that impedes the flow at normal temperature. After dilution the oil is chilled to crystallize the wax so that it can be filtered out. Hydrofinishing uses hydrogen and a catalyst to remove impurities.

- In percolation filtration, lube stock percolates through a tower filled with fuller's earth and bauxite to stabilize its color.

- Propane deasphalting produces "bright stock" lubricating oil from select crude oil in vacuum tower bottoms. Heavy reduced crude is mixed with and dissolves in propane; the lubricating oil is drawn off with the propane, leaving the asphalt behind.

- Blending various fractions into finished products is the final step in the refinery operation. In gasoline blending, an automated system meters and mixes into a finished product various components, or "blending stocks," from the process unit (e.g., butane, alkylate, isomerization stock, reformate, catalytic gasoline, naphtha or straight run gasoline) and various additives.

- The "light ends" recovery unit recaptures light hydrocarbon gases, such as methane, ethane, propane, and butane, some olefins and isobutane. The methane and ethane are used for refinery fuel. Then olefins and isobutane for alkylation feedstock may be separated from the recovered propane for liquefied petroleum gases and normal butane for gasoline blending.

- An acid gas treating system uses absorption in an alkaline solution to remove the "acid gases," hydrogen sulfide and carbon dioxide, from the "sour gas" produced in a number of refinery processes, before it can be used for refinery fuel. The acid gases can then be processed in a sulfur recovery unit.

- Sour water stripping is used to reduce hydrogen sulfide and ammonia levels in "sour water condensate," or water containing sulfides and ammonia, that is produced in various refinery operations.

- Storage tanks for crude oil, intermediate products, and finished products are necessary to the operation of the refinery, even though they are not directly involved in the operation of processing units.

- Steam generation systems provide steam for refinery processes, generate electric power, and run turbines for blowers.

- Receiving and distribution systems bring materials, crude oil, and products into the refinery and distribute finished products to the consumer. They include pumps, pipelines, storage tanks, tankers, tank cars, tank trucks, loading and unloading facilities. 
- Safety systems include flare and fire control systems. A flare system consists of pipes to collect gases, devices to remove liquid, and a terminal burner to flare (burn off) the gases safely. The fire control system includes a separate water system with storage pumps, piping, and water spray devices in process areas; sewer systems with seals, covers, traps, and baffles; foam systems; fire trucks and other specialized equipment; and firefighters.

- Environmental protection systems are often incorporated into the refinery processes themselves. Cooling systems use water and air to remove excess heat. Most water used by refineries is used for cooling. In some refineries, total recirculation has been achieved through air cooling and closed systems, greatly reducing the need for cooling water. Water pollution control systems used distillation to remove chemicals from contaminated water from process systems before the water is reused in other plant services or sent to the waste treatment facility and holding ponds. Waste water is also treated chemically so impurities can be filtered out. Some refineries have separate basins to segregate storm water runoff so its flow through the treatment facility can be kept to manageable levels.

- Air pollution control measures include chemical treatment and other measures to reduce sulfur emissions during production and scrubbers to remove sulfur from combustion gases and tail gases (residue gases from a sulfur recovery unit.) Vapor collection systems, floating tanks roofs, and seals are among the means used to reduce evaporation during storage. Particulate emissions from catalytic crackers are collected by electrostatic precipitators, scrubbers, and filters.

- Solid waste produced by various pollution control equipment requires careful handling. Sludge from water treatment facilities is incorporated in landfills. Oily wastes are deposited in selected sites. Powdery catalysts that contain valuable metals are returned to the manufacturers for recycling. 



\section{Glossary}

Alcohol. The family name of a group of organic chemical compounds composed of carbon, hydrogen, and oxygen. The series of molecules vary in chain length and are composed of a hydrocarbon plus a hydroxyl group; CH3-(CH2)n-OH (e.g., methanol, ethanol, and tertiary butyl alcohol).

Alkylate. The product of an alkylation reaction. It usually refers to the high octane product from alkylation units. This alkylate is used in blending high octane gasoline.

Alkylation. A refining process for chemically combining isobutane with olefin hydrocarbons (e.g., propylene, butylene) through the control of temperature and pressure in the presence of an acid catalyst, usually sulfuric acid or hydrofluoric acid. The product, alkylate, an isoparaffin, has high octane value and is blended with motor and aviation gasoline to improve the antiknock value of the fuel.

API Gravity. An arbitrary scale expressing the gravity or density of liquid petroleum products. The measuring scale is calibrated in terms of degrees API; it may be calculated in terms of the following formula:

$$
\text { Degrees API }=\frac{141.5}{s p . g r .60^{\circ} \mathrm{F} / 60^{\circ} \mathrm{F}}-131.5
$$

The higher the API gravity, the lighter the compound. Light crudes generally exceed 38 degrees API and heavy crudes are commonly labeled as all crudes with an API gravity of 22 degrees or below. Intermediate crudes fall in the range of 22 degrees to 38 degrees API gravity.

Aromatics. Hydrocarbons characterized by unsaturated ring structures of carbon atoms. Commercial petroleum aromatics are benzene, toluene, and xylene (BTX).

Asphalt. A dark-brown-to-black cement-like material containing bitumens as the predominant constituent obtained by petroleum processing. The definition includes crude asphalt as well as the following finished products: cements, fluxes, the asphalt content of emulsions (exclusive of water), and petroleum distillates blended with asphalt to make cutback asphalts. The conversion factor for asphalt is 5.5 barrels per short ton.

ASTM. The acronym for the American Society for Testing and Materials.
Atmospheric Crude Oil Distillation. The refining process of separating crude oil components at atmospheric pressure by heating to temperatures of about $600^{\circ}$ to $750^{\circ}$ $F$ (depending on the nature of the crude oil and desired products) and subsequent condensing of the fractions by cooling.

Aviation Gasoline (Finished). All special grades of gasoline for use in aviation reciprocating engines, as given in ASTM Specification D910 and Military Specification MIL-G-5572. Excludes blending components which will be used in blending or compounding into finished aviation gasoline.

Aviation Gasoline Blending Components. Naphthas which will be used for blending or compounding into finished aviation gasoline (e.g., straight-run gasoline, alkylate, reformate, benzene, toluene, and xylene). Excludes oxygenates (alcohols, ethers), butane, and pentanes plus. Oxygenates are reported as other hydrocarbons, hydrogen, and oxygenates.

Barrel. A volumetric unit of measure for crude oil and petroleum products equivalent to 42 U.S. gallons. This measure is used in most statistical reports. Factors for converting petroleum coke, asphalt, still gas and wax to barrels are given in the definitions of these products.

Barrels Per Calendar Day. The maximum number of barrels of input that can be processed during a 24-hour period after making allowances for the following limitations:

the capability of downstream facilities to absorb the output of crude oil processing facilities of a given refinery. No reduction is made when a planned distribution of intermediate streams through other than downstream facilities is part of a refinery's normal operation;

the types and grades of inputs to be processed;

the types and grades of products expected to be manufactured;

the environmental constraints associated with refinery operations;

the reduction of capacity for scheduled downtime such as routine inspection, mechanical problems, maintenance, repairs, and turnaround; and 
the reduction of capacity for unscheduled downtime such as mechanical problems, repairs, and slowdowns.

Barrels Per Stream Day. The amount a unit can process running at full capacity under optimal crude oil and product slate conditions.

Benzene $\left(\mathrm{C}_{6} \mathrm{H}_{6}\right)$. An aromatic hydrocarbon present in small proportion in some crude oils and made commercially from petroleum by the catalytic reforming of naphthenes in petroleum naphtha. Also made from coal in the manufacture of coke. Used as a solvent, in manufacturing detergents, synthetic fibers, and petrochemicals and as a component of high-octane gasoline.

Blending Components. See Motor or Aviation Gasoline Blending Components.

Blending Plant. A facility which has no refining capability but is either capable of producing finished motor gasoline through mechanical blending or blends oxygenates with motor gasoline.

Bonded Petroleum Imports. Petroleum imported and entered into Customs bonded storage. These imports are not included in the import statistics until they are: (1) withdrawn from storage free of duty for use as fuel for vessels and aircraft engaged in international trade; or (2) withdrawn from storage with duty paid for domestic use.

$B T X$. The acronym for the commercial petroleum aromatics benzene, toluene, and xylene. See individual categories for definitions.

Bulk Station. A facility used primarily for the storage and/or marketing of petroleum products which has a total bulk storage capacity of less than 50,000 barrels and receives its petroleum products by tank car or truck.

Bulk Terminal. A facility used primarily for the storage and/or marketing of petroleum products which has a total bulk storage capacity of 50,000 barrels or more and/or receives petroleum products by tanker, barge, or pipeline.

Butane $\left(\mathrm{C}_{4} \mathrm{H}_{10}\right)$. A normally gaseous straight-chain or branch-chain hydrocarbon extracted from natural gas or refinery gas streams. It includes isobutane and normal butane and is designated in ASTM Specification D1835 and Gas Processors Association Specifications for commercial butane.

Isobutane $\left(\mathrm{C}_{4} \mathrm{H}_{10}\right)$. A normally gaseous branch-chain hydrocarbon. It is a colorless paraffinic gas that boils at a temperature of $10.9^{\circ} \mathrm{F}$. It is extracted from natural gas or refinery gas streams.
Normal Butane $\left(\mathrm{C}_{4} \mathrm{H}_{10}\right)$. A normally gaseous straight-chain hydrocarbon. It is a colorless paraffinic gas that boils at a temperature of $31.1^{\circ} \mathrm{F}$. It is extracted from natural gas or refinery gas streams.

Butylene $\left(\mathrm{C}_{4} \mathrm{H}_{8}\right)$. An olefinic hydrocarbon recovered from refinery processes.

Captive Refinery Oxygenate Plants. Oxygenate production facilities located within or adjacent to a refinery complex.

Catalytic Cracking. The refining process of breaking down the larger, heavier, and more complex hydrocarbon molecules into simpler and lighter molecules. Catalytic cracking is accomplished by the use of a catalytic agent and is an effective process for increasing the yield of gasoline from crude oil. Catalytic cracking processes fresh feeds and recycled feeds.

Fresh Feeds. Crude oil or petroleum distillates which are being fed to processing units for the first time.

Recycled Feeds. Feeds that are continuously fed back for additional processing.

Catalytic Hydrocracking. A refining process that uses hydrogen and catalysts with relatively low temperatures and high pressures for converting middle boiling or residual material to high-octane gasoline, reformer charge stock, jet fuel, and/or high grade fuel oil. The process uses one or more catalysts, depending upon product output, and can handle high sulfur feedstocks without prior desulfurization.

Catalytic Hydrotreating. A refining process for treating petroleum fractions from atmospheric or vacuum distillation units (e.g., naphthas, middle distillates, reformer feeds, residual fuel oil, and heavy gas oil) and other petroleum (e.g., cat cracked naphtha, coker naphtha, gas oil, etc.) in the presence of catalysts and substantial quantities of hydrogen. Hydrotreating includes desulfurization, removal of substances (e.g., nitrogen compounds) that deactivate catalysts, conversion of olefins to paraffins to reduce gum formation in gasoline, and other processes to upgrade the quality of the fractions.

Catalytic Reforming. A refining process using controlled heat and pressure with catalysts to rearrange certain hydrocarbon molecules, thereby converting paraffinic and naphthenic type hydrocarbons (e.g., low-octane gasoline boiling range fractions) into petrochemical feedstocks and higher octane stocks suitable for blending into finished gasoline. Catalytic reforming is reported in two categories. They are: 
Low Pressure. A processing unit operating at less than 225 pounds per square inch gauge (PSIG) measured at the outlet separator.

High Pressure. A processing unit operating at either equal to or greater than 225 pounds per square inch gauge (PSIG) measured at the outlet separator.

Charge Capacity. The input (feed) capacity of the refinery processing facilities.

Commercial Kerosene-Type Jet Fuel. See Kerosene-Type Jet Fuel.

Contract Arrangements. Long-term contracts which specify the volumes of a commodity, such as crude oil, to be delivered and fix the price for a specified period of time.

Crude Oil (Including Lease Condensate). A mixture of hydrocarbons that exists in liquid phase in underground reservoirs and remains liquid at atmospheric pressure after passing through surface-separating facilities. Included are lease condensate and liquid hydrocarbons produced from tar sands, gilsonite, and oil shale. Drip gases are also included, but topped crude oil (residual oil) and other unfinished oils are excluded. Liquids produced at natural gas processing plants and mixed with crude oil are likewise excluded where identifiable. Crude oil is considered as either domestic or foreign, according to the following:

Domestic. Crude oil produced in the United States or from its "outer continental shelf" as defined in 43 USC 1331.

Foreign. Crude oil produced outside the United States. Imported Athabasca hydrocarbons (tar sands from Canada) are included.

Crude Oil Losses. Represents the volume of crude oil reported by petroleum refineries as being lost in their operations. These losses are due to spills, contamination, fires, etc. as opposed to refinery processing losses.

Crude Oil Production. The volume of crude oil produced from oil reservoirs during given periods of time. The amount of such production for a given period is measured as volumes delivered from lease storage tanks (i.e., the point of custody transfer) to pipelines, trucks, or other media for transport to refineries or terminals with adjustments for (1) net differences between opening and closing lease inventories, and (2) basic sediment and water (BS\&W).

Crude Oil Qualities. Refers to two properties of crude oil, the sulfur content and API gravity, which affect refinery processing complexity and product characteristics.
Crude Oil, Refinery Receipts. Receipts of domestic and foreign crude oil at a refinery. Includes all crude oil in transit except crude oil in transit by pipeline. Foreign crude oil is reported as a receipt only after entry through customs. Crude oil of foreign origin held in bonded storage is excluded.

Delayed Coking. A process by which heavier crude oil fractions can be thermally decomposed under conditions of elevated temperatures and pressure to produce a mixture of lighter oils and petroleum coke. The light oils can be processed further in other refinery units to meet product specifications. The coke can be used either as a fuel or in other applications such as the manufacturing of steel or aluminum.

Development Well. A well drilled within the proved area of an oil or gas reservoir to the depth of a stratigraphic horizon known to be productive.

Disposition. The components of petroleum disposition are stock change, crude oil losses, refinery inputs, exports, and products supplied for domestic consumption.

Distillate Fuel Oil. A general classification for one of the petroleum fractions produced in conventional distillation operations. It is used primarily for space heating, on-and-off-highway diesel engine fuel (including railroad engine fuel and fuel for agricultural machinery), and electric power generation. Included are products known as No. 1, No. 2, and No. 4 fuel oils; No. 1, No. 2, and No. 4 diesel fuels. Distillate fuel oil is reported in the following sulfur categories: $0.05 \%$ sulfur and under, for use in on-highway diesel engines which could be described as meeting EPA regulations; and greater than $0.05 \%$ sulfur, for use in all other distillate applications.

No. 1 Distillate. A petroleum distillate which meets the specifications for No. 1 heating or fuel oil as defined in ASTM D 396 and/or the specifications for No. 1 diesel fuel as defined in ASTM Specification D 975 with distillation temperatures of $420^{\circ} \mathrm{F}$ at the 10-percent recovery point and $550^{\circ} \mathrm{F}$ at the 90 -percent recovery point, and kinematic viscosities between 1.4 and 2.2 centistokes at $100^{\circ} \mathrm{F}$.

No. 2 Distillate. A petroleum distillate which meets the specifications for No. 2 heating or fuel oil as defined in ASTM D 396 and/or the specifications for No. 2 diesel fuel as defined in ASTM Specification D 975 with distillation temperatures of $540^{\circ}$ and $640^{\circ} \mathrm{F}$ at the 90-percent recovery point, and kinematic viscosities between 2.0 and 4.3 centistokes at $100^{\circ} \mathrm{F}$.

No. 4 Fuel Oil. A fuel oil for commercial burner installations not equipped with preheating facilities. It is used extensively in industrial plants. This grade is a blend 
of distillate fuel oil and residual fuel oil stocks that conforms to ASTM Specification D396 or Federal Specification VV-F-815C; with minimum and maximum kinematic viscosities between 5.8 and 26.4 centistokes at $100^{\circ} \mathrm{F}$. Also included is No. 4-D, a fuel oil for low and medium-speed diesel engines that conforms to ASTM Specification D975.

Electricity (Purchased). Electricity purchased for refinery operations that is not produced within the refinery complex.

Ending Stocks. Primary stocks of crude oil and petroleum products held in storage as of 12 midnight on the last day of the month. Primary stocks include crude oil or petroleum products held in storage at (or in) leases, refineries, natural gas processing plants, pipelines, tank farms, and bulk terminals that can store at least 50,000 barrels of petroleum products or that can receive petroleum products by tanker, barge, or pipeline. Crude oil that is in-transit by water from Alaska, or that is stored on Federal leases or in the Strategic Petroleum Reserve is included. Primary Stocks exclude stocks of foreign origin that are held in bonded warehouse storage.

ETBE (Ethyl tertiary butyl ether) $\left(\mathrm{CH}_{3}\right)_{3} \mathrm{COC}_{2} \mathrm{H}_{5}$. An oxygenate blend stock formed by the catalytic etherification of isobutylene with ethanol.

Ethane $\left(\mathrm{C}_{2} \mathrm{H}_{6}\right)$. A normally gaseous straight-chain hydrocarbon. It is a colorless paraffinic gas that boils at a temperature of $-127.48^{\circ} \mathrm{F}$. It is extracted from natural gas and refinery gas streams.

Ether. A generic term applied to a group of organic chemical compounds composed of carbon, hydrogen, and oxygen, characterized by an oxygen atom attached to two carbon atoms (e.g., methyl tertiary butyl ether).

Ethylene $\left(\mathrm{C}_{2} \mathrm{H}_{4}\right)$. An olefinic hydrocarbon recovered from refinery processes or petrochemical processes.

Exploratory Well. A well drilled to find and produce oil or gas in an unproved area; to find a new reservoir in a field previously found to be productive of oil or gas in another reservoir; or to extend the limit of a known oil or gas reservoir.

Exports. Shipments of crude oil and petroleum products from the 50 States and the District of Columbia to foreign countries, Puerto Rico, the Virgin Islands, and other U.S. possessions and territories.

Field. An area consisting of a single reservoir or multiple reservoirs all grouped on, or related to, the same individual geological structural feature and/or stratigraphic condition. There may be two or more reservoirs in a field that are separated vertically by intervening impervious strata, or laterally by local geologic barriers, or by both.

Field Area._A geographic area encompassing two or more pools that have a common gathering and metering system, the reserves of which are reported as a single unit. This concept applies primarily to the Appalachian region. (See Pool)

Field Production. Represents crude oil production on leases, natural gas liquids production at natural gas processing plants, new supply of other hydrocarbons/ oxygenates and motor gasoline blending components, and fuel ethanol blended into finished motor gasoline.

First Purchase (of crude oil). An equity (not custody) transaction involving an arms-length transfer of ownership of crude oil associated with the physical removal of the crude oil from a property (lease) for the first time. A first purchase normally occurs at the time and place of ownership transfer where the crude oil volume sold is measured and recorded on a run ticket or other similar physical evidence of purchase. The reported cost is the actual amount paid by the purchaser, allowing for any adjustments (deductions or premiums) passed on to the producer or royalty owner.

Flexicoking. A thermal cracking process which converts heavy hydrocarbons such as crude oil, tar sands bitumen, and distillation residues into light hydrocarbons. Feedstocks can be any pumpable hydrocarbons including those containing high concentrations of sulfur and metals.

Fluid Coking. A thermal cracking process utilizing the fluidized-solids technique to remove carbon (coke) for continuous conversion of heavy, low-grade oils into lighter products.

Fresh Feed Input. Represents input of material (crude oil, unfinished oils, natural gas liquids, other hydrocarbons and oxygenates or finished products) to processing units at a refinery that is being processed (input) into a particular unit for the first time.

\section{Examples:}

(1) Unfinished oils coming out of a crude oil distillation unit which are input into a catalytic cracking unit are considered fresh feed to the catalytic cracking unit.

(2) Unfinished oils coming out of a catalytic cracking unit being looped back into the same catalytic cracking unit to be reprocessed are not considered fresh feed. 
Fuel Ethanol $\left(\mathrm{C}_{2} \mathrm{H}_{5} \mathrm{OH}\right)$. An anhydrous denatured aliphatic alcohol intended for gasoline blending as described in Oxygenates definition.

Fuels Solvent Deasphalting. A refining process for removing asphalt compounds from petroleum fractions, such as reduced crude oil. The recovered stream from this process is used to produce fuel products.

Futures Contract. A promise to deliver a specified quantity of a specified commodity at a specified place, price, and time in the future.

Gas Oil. A liquid petroleum distillate having a viscosity intermediate between that of kerosene and lubricating oil. It derives its name from having originally been used in the manufacture of illuminating gas. It is now used to produce distillate fuel oils and gasoline.

Gasohol. A blend of finished motor gasoline and alcohol (generally ethanol but sometimes methanol), limited to 10 percent by volume of alcohol.

Gasoline Blending Components. Naphthas which will be used for blending or compounding into finished aviation or motor gasoline (e.g., straight-run gasoline, alkylate, reformate, benzene, toluene, and xylene). Excludes oxygenates (alcohols, ethers), butane, and pentanes plus.

Gross Input to Atmospheric Crude Oil Distillation Units. Total input to atmospheric crude oil distillation units. Includes all crude oil, lease condensate, natural gas plant liquids, unfinished oils, liquefied refinery gases, slop oils, and other liquid hydrocarbons produced from tar sands, gilsonite, and oil shale.

Heavy Gas Oil. Petroleum distillates with an approximate boiling range from $651^{\circ}$ to $1000^{\circ} \mathrm{F}$.

\section{Hydrocracking. (See Catalytic Hydrocracking)}

Hydrogen. The lightest of all gases, occurring chiefly in combination with oxygen in water; exists also in acids, bases, alcohols, petroleum, and other hydrocarbons.

\section{Hydrotreating. (See Catalytic Hydrotreating)}

Idle Capacity. The component of operable capacity that is not in operation and not under active repair, but capable of being placed in operation within 30 days; and capacity not in operation but under active repair that can be completed within 90 days.

Imported Crude Oil Burned As Fuel. The amount of foreign crude oil burned as a fuel oil, usually as residual fuel oil, without being processed as such. Imported crude oil burned as fuel includes lease condensate and liquid hydrocarbons produced from tar sands, gilsonite, and oil shale.

Imports. Receipts of crude oil and petroleum products into the 50 States and the District of Columbia from foreign countries, Puerto Rico, the Virgin Islands, and other U.S. possessions and territories.

Indicated Additional Reserves of Crude Oil. Quantities of crude oil (other than proved reserves) which may become economically recoverable from existing productive reservoirs through the applicaton of improved recovery techniques using current technology. These recovery techniques may:

1. Already be installed in the reservoir, but their effects are not yet known to the degree necessary to classify the additional reserves as proved;

2. Be installed in another similar reservoir, where the results of that installation can be used to estimate the indicated additional reserves.

Indicated additional reserves are not included in proved reserves due to their uncertain economic recoverability. When economic recoverability is demonstrated, the indicated additional reserves must be transferred to proved reserves as positive revisions.

\section{Isobutane. See Butane.}

Isobutylene $\left(\mathrm{C}_{4} \mathrm{H}_{8}\right)$. An olefinic hydrocarbon recovered from refinery processes or petrochemical processes.

Isohexane $\left(\mathrm{C}_{6} \mathrm{H}_{14}\right)$. A saturated branch-chain hydrocarbon. It is a colorless liquid that boils at a temperature of $156.2^{\circ} \mathrm{F}$.

Isomerization. A refining process which alters the fundamental arrangement of atoms in the molecule without adding or removing anything from the original material. Used to convert normal butane into isobutane $\left(\mathrm{C}_{4}\right)$, an alkylation process feedstock, and normal pentane and hexane into isopentane $\left(\mathrm{C}_{5}\right)$ and isohexane $\left(\mathrm{C}_{6}\right)$, high-octane gasoline components.

Isopentane. See Natural Gasoline and Isopentane.

Kerosene. A petroleum distillate that has a maximum distillation temperature of $401^{\circ} \mathrm{F}$ at the 10 -percent recovery point, a final boiling point of $572^{\circ} \mathrm{F}$, and a minimum flash point of $100^{\circ} \mathrm{F}$. Included are the two grades designated in ASTM D3699: No. 1-K and No. 2-K, and all grades of kerosene called range or stove oil. Kerosene is used in space heaters, cook stoves, and water 
heaters and is suitable for use as an illuminant when burned in wick lamps.

Kerosene-Type Jet Fuel. A quality kerosene product with a maximum distillation temperature of $400^{\circ} \mathrm{F}$ at the 10-percent recovery point and a final maximum boiling point of $572^{\circ} \mathrm{F}$. The fuel is designated in ASTM Specification D1655 and Military Specifications MIL-T-5624R and MIL-T-83133D (Grades JP-5 and JP-8). A relatively low-freezing point distillate of the kerosene type used primarily for turbojet and turboprop aircraft engines.

Commercial. Kerosene-type jet fuel intended for use in commercial aircraft.

Military. Kerosene-type jet fuel intended for use in military aircraft.

Lease Condensate. A natural gas liquid recovered from gas well gas (associated and non-associated) in lease separators or natural gas field facilities. Lease condensate consists primarily of pentanes and heavier hydrocarbons.

Light Gas Oils. Liquid petroleum distillates heavier than naphtha, with an approximate boiling range from $401^{\circ} \mathrm{F}$ to $650^{\circ} \mathrm{F}$

Liquefied Petroleum Gases (LPG). Ethane, ethylene, propane, propylene, normal butane, butylene, isobutane, and isobutylene produced at refineries or natural gas processing plants, including plants that fractionate raw natural gas plant liquids.

Liquefied Refinery Gases (LRG). Liquefied petroleum gases fractionated from refinery or still gases. Through compression and/or refrigeration, they are retained in the liquid state. The reported categories are ethane/ethylene, propane/propylene, normal butane/butylene, and isobutane/isobutylene. Excludes still gas.

Lubricants. A substance used to reduce friction between bearing surfaces or as process materials either incorporated into other materials used as processing aids in the manufacturing of other products, or as carriers of other materials. Petroleum lubricants may be produced either from distillates or residues. Other substances may be added to impart or improve certain required properties. Do not include byproducts of lubricating oil refining such as aromatic extracts derived from solvent extraction or tars derived from deasphalting. "Lubricants" includes all grades of Iubricating oils from spindle oil to cylinder oil and those used in greases. Reporting categories include:

Paraffinic. Includes all grades of bright stock and neutrals with a Viscosity Index $>75$.
Naphthenic. Includes all lubricating oil base stocks with a Viscosity Index $<75$.

Note: The criterion for categorizing the lubricants is based solely on the Viscosity Index of the stocks and is independent of crude sources and type of processing used to produce the oils.

Exceptions: Lubricating oil base stocks that have been historically classified as naphthenic or paraffinic by a refiner may continue to be so categorized irrespective of the Viscosity Index criterion.

Example:

(1) Unextracted paraffinic oils that would not meet the Viscosity Index test.

Merchant Oxygenate Plants. Oxygenate production facilities that are not associated with a petroleum refinery. Production from these facilities is sold under contract or on the spot market to refiners or other gasoline blenders.

Methanol $\left(\mathrm{CH}_{3} \mathrm{OH}\right)$. A light, volatile alcohol intended for gasoline blending as described in Oxygenate definition.

Middle Distillates. A general classification of refined petroleum products that includes distillate fuel oil and kerosene.

Military Kerosene-Type Jet Fuel. See Kerosene-Type Jet Fuel.

Miscellaneous Products. Includes all finished products not classified elsewhere (e.g., petrolatum, lube refining byproducts (aromatic extracts and tars), absorption oils, ram-jet fuel, petroleum rocket fuels, synthetic natural gas feedstocks, and specialty oils).

Motor Gasoline (Finished). A complex mixture of relatively volatile hydrocarbons, with or without small quantities of additives, that has been blended to form a fuel suitable for use in spark-ignition engines. Motor gasoline, as given in ASTM Specification D-4814 or Federal Specification VV-G-1690C, includes a range in distillation temperatures from 122 degrees to 158 degrees $F$ at the 10-percent recovery point and from 365 degrees to 374 degrees $F$ at the 90 -percent recovery point. "Motor gasoline" includes reformulated gasoline, oxygenated gasoline, and other finished gasoline. Blendstock is excluded until blending has been completed.

Reformulated Gasoline. Gasoline formulated for use in motor vehicles, the composition and properties of which meet the requirements of the reformulated gasoline regulations promulgated by the U.S. Environmental 
Protection Agency under Section $211 \mathrm{~K}$ of the Clean Air Act. Includes oxygenated fuels program reformulated gasoline (OPRG). Excludes reformulated gasoline blendstock for oxygenate blending (RBOB).

Oxygenated Gasoline. Gasoline formulated for use in motor vehicles that has an oxygen content of 1.8 percent or higher, by weight. Includes gasohol. Excludes reformulated gasoline, oxygenated fuels program reformulated gasoline (OPRG) and reformulated gasoline blendstock for oxygenate blending (RBOB).

OPRG. "Oxygenated Fuels Program Reformulated Gasoline" is reformulated gasoline which is intended for use in an oxygenated fuels program control period.

Other Finished or Conventional Gasoline. Motor gasoline not included in the oxygenated or reformulated gasoline categories. Excludes reformulated gasoline blendstock for oxygenate blending (RBOB).

Motor Gasoline Blending. Mechanical mixing of motor gasoline blending components and oxygenates to produce finished motor gasoline. Mechanical mixing of finished motor gasoline with motor gasoline blending components or oxygenates which results in increased volumes of finished motor gasoline, and/or changes in the classification of finished motor gasoline (e.g., other finished motor gasoline mixed with MTBE to produce oxygenated motor gasoline), is considered motor gasoline blending.

Motor Gasoline Blending Components. Naphthas which will be used for blending or compounding into finished motor gasoline (e.g., straight-run gasoline, alkylate, reformate, benzene, toluene, xylene) and includes reformulated gasoline blendstock for oxygenate blending (RBOB). Excludes oxygenates (alcohols, ethers), butane, and pentanes plus. Oxygenates are reported as individual components and included in the total for other hydrocarbons, hydrogens, and oxygenates.

MTBE (Methyl tertiary butyl ether) $\left(\mathrm{CH}_{3}\right)_{3} \mathrm{COCH}_{3}$. An ether intended for gasoline blending as described in Oxygenate definition.

Naphtha. A generic term applied to a petroleum fraction with an approximate boiling range between $122^{\circ}$ and $400^{\circ}$ F.

Naphtha Less Than $401^{\circ} \mathrm{F}$. See Petrochemical Feedstocks.

Naphtha-Type Jet Fuel. A fuel in the heavy naphtha boiling range. ASTM Specification D1655 specifies for this fuel maximum distillation temperatures of $290^{\circ} \mathrm{F}$ at the 20 -percent recovery point and $470^{\circ} \mathrm{F}$ at the 90 -percent point, meeting Military Specification MIL-T-5624L (Grade JP-4). JP-4 is used for turbojet and turboprop aircraft engines, primarily by the military. Excludes ram-jet and petroleum rocket fuels.

Natural Gas. A mixture of hydrocarbons and small quantities of various nonhydrocarbons existing in the gaseous phase or in solution with crude oil in underground reservoirs.

Natural Gas Field Facility. A field facility designed to process natural gas produced from more than one lease for the purpose of recovering condensate from a stream of natural gas; however, some field facilities are designed to recover propane, normal butane, pentanes plus, etc., and to control the quality of natural gas to be marketed.

Natural Gas Plant Liquids. Natural gas liquids recovered from natural gas in gas processing plants, and in some situations, from natural gas field facilities. Natural gas liquids extracted by fractionators are also included. These liquids are defined according to the published specifications of the Gas Processors Association and the American Society for Testing and Materials and are classified as follows: ethane, propane, normal butane, isobutane, and pentanes plus.

Natural Gas Processing Plant. A facility designed (1) to achieve the recovery of natural gas liquids from the stream of natural gas which may or may not have been processed through lease separators and field facilities, and (2) to control the quality of the natural gas to be marketed. Cycling plants are classified as gas processing plants.

Natural Gasoline and Isopentane. A mixture of hydrocarbons, mostly pentanes and heavier, extracted from natural gas, that meets vapor pressure, end-point, and other specifications for natural gasoline set by the Gas Processors Association. Includes isopentane which is a saturated branch-chain hydrocarbon, $\left(\mathrm{C}_{5} \mathrm{H}_{12}\right)$, obtained by fractionation of natural gasoline or isomerization of normal pentane.

Net Receipts. The difference between total movements into and total movements out of each PAD District by pipeline, tanker, and barge.

\section{Normal Butane. See Butane.}

OPEC. The acronym for the Organization of Petroleum Exporting Countries, that have organized for the purpose of negotiating with oil companies on matters of oil production, prices and future concession rights. Current members are Algeria, Indonesia, Iran, Iraq, Kuwait, Libya, Nigeria, Qatar, Saudi Arabia, United Arab Emirates, and Venezuela. The Neutral Zone between Kuwait and Saudi Arabia is considered part of OPEC. 
Prior to January 1, 1993, Ecuador was a member of OPEC. Prior to January 1995, Gabon was a member of OPEC.

OPRG. "Oxygenated Fuels Program Reformulated Gasoline" is reformulated gasoline which is intended for use in an oxygenated fuels program control area during an oxygenated fuels program control period.

Operable Capacity. The amount of capacity that, at the beginning of the period, is in operation; not in operation and not under active repair, but capable of being placed in operation within 30 days; or not in operation but under active repair that can be completed within 90 days. Operable capacity is the sum of the operating and idle capacity and is measured in barrels per calendar day or barrels per stream day.

Operating Capacity. The component of operable capacity that is in operation at the beginning of the period.

Operable Utilization Rate. Represents the utilization of the atmospheric crude oil distillation units. The rate is calculated by dividing the gross input to these units by the operable refining capacity of the units.

Operating Utilization Rate. Represents the utilization of the atmospheric crude oil distillation units. The rate is calculated by dividing the gross input to these units by the operating refining capacity of the units.

Other Finished. See Motor Gasoline (Finished).

Other Hydrocarbons. Materials received by a refinery and consumed as a raw material. Includes hydrogen, coal tar derivatives, gilsonite, and natural gas received by the refinery for reforming into hydrogen. Natural gas to be used as fuel is excluded.

Other Oils Equal To or Greater Than $401^{\circ} \mathrm{F}$. See Petrochemical Feedstocks.

Other Oxygenates. Other aliphatic alcohols and aliphatic ethers intended for motor gasoline blending (e.g., isopropyl ether (IPE) or n-propanol).

Outer Continental Shelf $(O C S)$. U.S. offshore waters that are under Federal domain.

Oxygenated Gasoline. See Motor Gasoline (Finished).

Oxygenates. Any substance which, when added to gasoline, increases the amount of oxygen in that gasoline blend. Through a series of waivers and interpretive rules, the Environmental Protection Agency (EPA) has determined the allowable limits for oxygenates in unleaded gasoline. The "Substantially Similar"
Interpretive Rules (56 FR (February 11, 1991)) allows blends of aliphatic alcohols other than methanol and aliphatic ethers, provided the oxygen content does not exceed 2.7 percent by weight. The "Substantially Similar" Interpretive Rules also provides for blends of methanol up to 0.3 percent by volume exclusive of other oxygenates, and butanol or alcohols of a higher molecular weight up to 2.75 percent by weight. Individual waivers pertaining to the use of oxygenates in unleaded gasoline have been issued by the EPA. They include:

Fuel Ethanol. Blends of up to 10 percent by volume anhydrous ethanol (200 proof) (commonly referred to as the "gasohol waiver").

Methanol. Blends of methanol and gasoline-grade tertiary butyl alcohol (GTBA) such that the total oxygen content does not exceed 3.5 percent by weight and the ratio of methanol to GTBA is less than or equal to 1 . It is also specified that this blended fuel must meet ASTM volatility specifications (commonly referred to as the "ARCO" waiver).

Blends of up to 5.0 percent by volume methanol with a minimum of 2.5 percent by volume cosolvent alcohols having a carbon number of 4 or less (i.e., ethanol, propanol, butanol, and/or GTBA). The total oxygen must not exceed 3.7 percent by weight, and the blend must meet ASTM volatility specifications as well as phase separation and alcohol purity specifications (commonly referred to as the "DuPont" waiver).

MTBE (Methyl tertiary butyl ether). Blends up to 15.0 percent by volume MTBE which must meet the ASTM D4814 specifications. Blenders must take precautions that the blends are not used as base gasolines for other oxygenated blends (commonly referred to as the "Sun" waiver).

Pentanes Plus. A mixture of hydrocarbons, mostly pentanes and heavier, extracted from natural gas. Includes isopentane, natural gasoline, and plant condensate.

Persian Gulf. The countries that comprise the Persian Gulf are: Bahrain, Iran, Iraq, Kuwait, Qatar, Saudi Arabia, and the United Arab Emirates.

Petrochemical Feedstocks. Chemical feedstocks derived from petroleum principally for the manufacture of chemicals, synthetic rubber, and a variety of plastics. The categories reported are "Naphtha Less Than $401^{\circ} \mathrm{F}$ " and "Other Oils Equal To or Greater Than $401^{\circ}$ F."

Naphtha Less Than $401^{\circ} \mathrm{F}$. A naphtha with a boiling range of less than $401^{\circ} \mathrm{F}$ that is intended for use as a petrochemical feedstock. 
Other Oils Equal To or Greater Than $401^{\circ} \mathrm{F}$. Oils with a boiling range equal to or greater than $401^{\circ} \mathrm{F}$ that are intended for use as a petrochemical feedstock.

Petroleum Administration for Defense (PAD) Districts. Geographic aggregations of the 50 States and the District of Columbia into five districts by the Petroleum Administration for Defense in 1950. These districts were originally defined during World War II for purposes of administering oil allocation.

Petroleum Coke. A residue, the final product of the condensation process in cracking. This product is reported as marketable coke or catalyst coke. The conversion factor is 5 barrels per short ton.

Marketable Coke. Those grades of coke produced in delayed or fluid cokers which may be recovered as relatively pure carbon. This "green" coke may be sold as is or further purified by calcining.

Catalyst Coke. In many catalytic operations (e.g., catalytic cracking) carbon is deposited on the catalyst, thus deactivating the catalyst. The catalyst is reactivated by burning off the carbon, which is used as a fuel in the refining process. This carbon or coke is not recoverable in a concentrated form.

Petroleum Products. Petroleum products are obtained from the processing of crude oil (including lease condensate), natural gas, and other hydrocarbon compounds. Petroleum products include unfinished oils, liquefied petroleum gases, pentanes plus, aviation gasoline, motor gasoline, naphtha-type jet fuel, kerosene-type jet fuel, kerosene, distillate fuel oil, residual fuel oil, petrochemical feedstocks, special naphthas, lubricants, waxes, petroleum coke, asphalt, road oil, still gas, and miscellaneous products.

Pipeline (Petroleum). Crude oil and product pipelines used to transport crude oil and petroleum products respectively, (including interstate, intrastate, and intracompany pipelines) within the 50 States and the District of Columbia.

Plant Condensate. One of the natural gas liquids, mostly pentanes and heavier hydrocarbons, recovered and separated as liquids at gas inlet separators or scrubbers in processing plants.

Pool. In general, a reservoir. In certain situations a pool may consist of more than one reservoir. (See Field Area)

Processing Gain. The volumetric amount by which total output is greater than input for a given period of time. This difference is due to the processing of crude oil into products which, in total, have a lower specific gravity than the crude oil processed.

Processing Loss. The volumetric amount by which total refinery output is less than input for a given period of time. This difference is due to the processing of crude oil into products which, in total, have a higher specific gravity than the crude oil processed.

Product Supplied, Crude Oil. Crude oil burned on leases and by pipelines as fuel.

Production Capacity. The maximum amount of product that can be produced from processing facilities.

Products Supplied. Approximately represents consumption of petroleum products because it measures the disappearance of these products from primary sources, i.e., refineries, natural gas processing plants, blending plants, pipelines, and bulk terminals. In general, product supplied of each product in any given period is computed as follows: field production, plus refinery production, plus imports, plus unaccounted for crude oil, (plus net receipts when calculated on a PAD District basis), minus stock change, minus crude oil losses, minus refinery inputs, minus exports.

Propane $\left(\mathrm{C}_{3} \mathrm{H}_{8}\right)$. A normally gaseous straight-chain hydrocarbon. It is a colorless paraffinic gas that boils at a temperature of $-43.67^{\circ} \mathrm{F}$. It is extracted from natural gas or refinery gas streams. It includes all products designated in ASTM Specification D1835 and Gas Processors Association Specifications for commercial propane and HD-5 propane.

Propylene $\left(\mathrm{C}_{3} \mathrm{H}_{6}\right)$. An olefinic hydrocarbon recovered from refinery processes or petrochemical processes.

Proved Reserves of Crude Oil. Proved reserves of crude oil as of December 31 of a given year are the estimated quantities of all liquids defined as crude oil, which geological and engineering data demonstrate with reasonable certainty to be recoverable in future years from known reservoirs under existing economic and operating conditions.

Reservoirs are considered proved if economic producibility is supported by actual production or conclusive formation tests (drill stem or wire line), or if economic producibility is supported by core analyses and/or electric or other log interpretations. The area of an oil reservoir considered proved includes (1) that portion delineated by drilling and defined by gas-oil and/or oil-water contacts, if any; and (2) the immediately adjoining portions not yet drilled, but which can be reasonably judged as economically productive on the basis of available geological and engineering data. In the 
absence of information on fluid contacts, the lowest known structural occurrence of hydrocarbons is considered to be the lower proved limit of the reservoir.

Volumes of crude oil placed in underground storage are not to be considered proved reserves.

Reserves of crude oil which can be produced economically through application of improved recovery techniques (such as fluid injection) are included in the "proved" classification when successful testing by a pilot project, or the operation of an installed program in the reservoir, provides support for the engineering analysis on which the project or program was based.

Estimates of proved crude oil reserves do not include the following: (1) oil that may become available from known reservoirs but is reported separately as "indicated additional reserves"; (2) natural gas liquids (including lease condensate); (3) oil, the recovery of which is subject to reasonable doubt because of uncertainty as to geology, reservoir characteristics, or economic factors; (4) oil that may occur in undrilled prospects; and (5) oil that may be recovered from oil shales, coal, gilsonite, and other such sources. It is not necessary that production, gathering or transportation facilities be installed or operative for a reservoir to be considered proved.

Proved Reserves of Natural Gas Liquids. Proved reserves of natural gas liquids as of December 31 of a given year are those volumes of natural gas liquids (including lease condensate) demonstrated with reasonable certainty to be separable in the future from proved natural gas reserves, under existing economic and operating conditions.

$R B O B$. "Reformulated Gasoline Blendstock for Qxygenate Blending" is a motor gasoline blending component which, when blended with a specified type and percentage of oxygenate, meets the definition of reformulated gasoline.

Refiner Acquisition Cost. The cost of crude oil to the refiner, including transportation and fees. The composite cost is the weighted average of domestic and imported crude oil costs.

Refinery. An installation that manufactures finished petroleum products from crude oil, unfinished oils, natural gas liquids, other hydrocarbons, and oxygenates.

Refinery Capacity Utilization. (See Operable Utilization Rate and Operating Utilization Rate)

Refinery Input, Crude Oil. Total crude oil (domestic plus foreign) input to crude oil distillation units and other refinery processing units (cokers, etc.).
Refinery Input, Total. The raw materials and intermediate materials processed at refineries to produce finished petroleum products. They include crude oil, products of natural gas processing plants, unfinished oils, other hydrocarbons and oxygenates, motor gasoline and aviation gasoline blending components and finished petroleum products.

Refinery Production. Petroleum products produced at a refinery or blending plant. Published production of these products equals refinery production minus refinery input. Negative production will occur when the amount of a product produced during the month is less than the amount of that same product that is reprocessed (input) or reclassified to become another product during the same month. Refinery production of unfinished oils, and motor and aviation gasoline blending components appear on a net basis under refinery input.

Refinery Yield. Refinery yield (expressed as a percentage) represents the percent of finished product produced from input of crude oil and net input of unfinished oils. It is calculated by dividing the sum of crude oil and net unfinished input into the individual net production of finished products. Before calculating the yield for finished motor gasoline, the input of natural gas liquids, other hydrocarbons and oxygenates, and net input of motor gasoline blending components must be subtracted from the net production of finished motor gasoline. Before calculating the yield for finished aviation gasoline, input of aviation gasoline blending components must be subtracted from the net production of finished aviation gasoline.

\section{Reformulated Gasoline. See Motor Gasoline (Finished).}

Reseller. A firm (other than a refiner) that carries on the trade or business of purchasing refined petroleum products and reselling them to purchasers other than ultimate consumers; e.g., retailers at the gasoline service stations.

Reseller/Retailer. A firm (other than a refiner) that carries on the trade or business activities of both a reseller and a retailer; i.e., purchasing refined petroleum products and reselling them to purchasers who may be either ultimate or other than ultimate consumers.

Reserve Additions. Consist of adjustments, net revisions, extensions to old reservoirs, new reservoir discoveries in old fields, and new field discoveries.

Reserves. (See Proved Reserves)

Reserves Changes. Positive and negative revisions, extensions, new reservoir discoveries in old fields, and 
new field discoveries, which occurred during a given year.

Reserves Extensions. The reserves credited to a reservoir because of enlargement of its proved area. Normally the ultimate size of newly discovered fields, or newly discovered reservoirs in old fields, is determined by wells drilled in years subsequent to discovery. When such wells add to the proved area of a previously discovered reservoir. the increase in proved reserves is classified as an extension.

Reserves Revisions. Changes to prior year-end proved reserves estimates, either positive or negative, resulting from new information other than an increase in proved acreage (extension). Revisions include increases of proved reserves associated with the installation of improved recovery techniques or equipment. They also include correction of prior report year arithmetical or clerical errors and adjustments to prior year-end production volumes to the extent that these alter reported prior year reserves estimates.

Reservoir. A porous and permeable underground formation containing an individual and separate natural accumulation of producible hydrocarbons (oil and/or gas) which is confined by impermeable rock or water barriers and is characterized by a single natural presure system.

Residual Fuel Oil. The heavier oils that remain after the distillate fuel oils and lighter hydrocarbons are distilled away in refinery operations and that conform to ASTM Specification D396. Included are No. 5, a residual fuel oil of medium viscosity; Navy Special, for use in steam-powered vessels in government service and in shore power plants; No. 6 , which includes Bunker $C$ fuel oil, and is used for commercial and industrial heating, electricity generation and to power ships.

Residuum. Residue from crude oil after distilling off all but the heaviest components, with a boiling range greater than $1000^{\circ} \mathrm{F}$.

Retailer. A firm (other than a refiner, reseller, or reseller/retailer) that carries on the trade or business of purchasing refined petroleum products and reselling them to ultimate consumers.

Road Oil. Any heavy petroleum oil, including residual asphaltic oil used as a dust pallative and surface.treatment on roads and highways. It is generally produced in six grades from 0 , the most liquid, to 5 , the most viscous.
Rotary Rig. A machine, used for drilling wells, that employs a rotating tube attached to a bit for boring holes through rock.

Sales for Resale. Sales of refined petroleum products to purchasers who are other-than-ultimate consumers; wholesale sales.

Sales to End Users. Sales made directly to the consumer of the product. Includes bulk consumers, such as agriculture, industry, and utilities, as well as residential and commercial consumers.

Shell Storage Capacity. The design capacity of a petroleum storage tank which is always greater than or equal to working storage capacity.

Special Naphthas. All finished products within the naphtha boiling range that are used as paint thinners, cleaners, or solvents. These products are refined to a specified flash point. Special naphthas include all commercial hexane and cleaning solvents conforming to ASTM Specification D1836 and D484, respectively. Naphthas to be blended or marketed as motor gasoline or aviation gasoline, or that are to be used as petrochemical and synthetic natural gas (SNG) feedstocks are excluded.

Spot Price. A transaction price concluded "on the spot", that is, on a one-time, prompt basis to sell or buy one shipment of a commodity, such as crude oil.

Steam (Purchased). Steam, purchased for use by a refinery, that was not generated from within the refinery complex.

Still Gas (Refinery Gas). Any form or mixture of gases produced in refineries by distillation, cracking, reforming, and other processes. The principal constituents are methane, ethane, ethylene, normal butane, butylene, propane, propylene, etc. Still gas is used as a refinery fuel and a petrochemical feedstock. The conversion factor is 6 million BTU's per fuel oil equivalent barrel.

Stock Change. The difference between stocks at the beginning of the month and stocks at the end of the month. A negative number indicates a decrease in stocks and a positive number indicates an increase in stocks.

Stocks, Crude Oil. Crude oil and lease condensate held at refineries, in pipelines, at pipeline terminals, and on leases.

Stocks, Primary. Stocks of crude oil or petroleum products held in storage at (or in) leases, refineries, natural gas processing plants, pipelines, tank farms, and bulk terminals. Crude oil that is in transit from Alaska, or that is 
stored on Federal leases or in the Strategic Petroleum Reserve, is included. Excluded are stocks of foreign origin that are held in bonded warehouse storage.

Strategic Petroleum Reserve (SPR). Petroleum stocks maintained by the Federal Government for use during periods of major supply interruption.

Sulfur. A yellowish nonmetallic element, sometimes known as "brimstone".

Supply. The components of petroleum supply are field production, refinery production, imports, and net receipts when calculated on a PAD District basis.

TAME (Tertiary amyl methyl ether) $\left(\mathrm{CH}_{3}\right)_{2}\left(\mathrm{C}_{2} \mathrm{H}_{5}\right)_{\mathrm{COCH}}$. An oxygenate blend stock formed by the catalytic etherification of isoamylene with methanol.

Tank Farm. An installation used by gathering and trunk pipeline companies, crude oil producers, and terminal operators (except refineries) to store crude oil.

Tanker and Barge. Vessels that transport crude oil or petroleum products. Data are reported for movements between PAD Districts; from a PAD District to the Panama Canal; or from the Panama Canal to a PAD District.

TBA (Tertiary butyl alcohol) $\left(\mathrm{CH}_{3}\right)_{3} \mathrm{COH}$. An alcohol primarily used as a chemical feedstock, a solvent or feedstock for isobutylene production for MTBE; produced as a co-product of propylene oxide production or by direct hydration of isobutylene.

Thermal Cracking. A refining process in which heat and pressure are used to break down, rearrange, or combine hydrocarbon molecules. Thermal cracking includes gas oil, visbreaking, fluid coking, delayed coking, and other thermal cracking processes (e.g., flexicoking). See individual categories for definition.

Toluene $\left(\mathrm{C}_{6} \mathrm{H}_{5} \mathrm{CH}_{3}\right)$. Colorless liquid of the aromatic group of petroleum hydrocarbons, made by the catalytic reforming of petroleum naphthas containing methyl cyclohexane. A high-octane gasoline-blending agent, solvent, and chemical intermediate, base for TNT.

Ultimate Recovery Appreciation. The commonly observed increase overtime of the sum of cumulative production on a specific day and the estimate of proved reserves on that same day. Also known as "reserves growth."

Unaccounted for Crude Oil. Represents the arithmetic difference between the calculated supply and the calculated disposition of crude oil. The calculated supply is the sum of crude oil production plus imports minus changes in crude oil stocks. The calculated disposition of crude oil is the sum of crude oil input to refineries, crude oil exports, crude oil burned as fuel, and crude oil losses.

Undiscovered Recoverable Resources (crude oil and natural gas). Those economic resources of crude oil and natural gas, yet undiscovered, that are estimated to exist in favorable geologic settings.

Unfinished Oils. Includes all oils requiring further processing, except those requiring only mechanical blending. Includes naphthas and lighter oils, kerosene and light gas oils, heavy gas oils, and residuum. See individual categories for definition.

Unfractionated Streams. Mixtures of unsegregated natural gas liquid components excluding those in plant condensate. This product is extracted from natural gas.

United States. The United States is defined as the 50 States and the District of Columbia.

Vacuum Distillation. Distillation under reduced pressure (less the atmospheric) which lowers the boiling temperature of the liquid being distilled. This technique with its relatively low temperatures prevents cracking or decomposition of the charge stock.

Visbreaking. A thermal cracking process in which heavy atmospheric or vacuum-still bottoms are cracked at moderate temperatures to increase production of distillate products and reduce viscosity of the distillation residues.

Wax. A solid or semi-solid material consisting of a mixture of hydrocarbons obtained or derived from petroleum fractions, or through a Fischer-Tropsch type process, in which the straight chained paraffin series predominates. This includes all marketable wax, whether crude or refined, with a congealing point (ASTM D 938) between 100 and $200^{\circ} \mathrm{F}$ and a maximum oil content (ASTM D 3235) of 50 weight percent. The conversion factor is 280 pounds per 42 U.S. gallons per barrel.

Well. A hole drilled for the purpose of finding or producing crude oil or natural gas or providing services related to the production of crude oil or natural gas. Wells are classified as oil wells, gas wells, dry holes, stratigraphic or core tests, or service wells.

Working Storage Capacity. The difference in volume between the maximum safe fill capacity and the quantity below which pump suction is ineffective (bottoms). 
Xylene $\left(\mathrm{C}_{6} \mathrm{H}_{4}\left(\mathrm{CH}_{3}\right)_{2}\right)$. Colorless liquid of the aromatic group of hydrocarbons made the catalytic reforming of certain naphthenic petroleum fractions. Used as high-octane motor and aviation gasoline blending agents, solvents, chemical intermediates. Isomers are metaxylene, orthoxylene, paraxylene. 
